UNIVERSIDADE DE SÃO PAULO

FACULDADE DE FILOSOFIA, CIÊNCIAS E LETRAS DE RIBEIRÃO PRETO PROGRAMA DE PÓS-GRADUAÇÃO EM EDUCAÇÃO

\title{
ASSOCIAÇÃO DE SURDOS DE SÃO PAULO: IDENTIDADE COLETIVA E LUTAS SOCIAIS NA CIDADE DE SÃO PAULO
}

NATALIA FRANCISCA FRAZÃO

RIBEIRÃO PRETO - SP

2017 
NATALIA FRANCISCA FRAZÃO

\section{ASSOCIAÇÃO DE SURDOS DE SÃO PAULO: IDENTIDADE COLETIVA E LUTAS SOCIAIS NA CIDADE DE SÃO PAULO}

Dissertação apresentada ao Programa de PósGraduação em Educação da Faculdade de Filosofia, Ciências e Letras de Ribeirão Preto da Universidade de São Paulo para obtenção do título de Mestre em Ciências, no Programa Educação.

Área de Concentração: Educação

Orientadora: $\operatorname{Prof}^{\mathrm{a}} \mathrm{Dr}^{\mathrm{a}}$ Ana Claudia Balieiro Lodi

VERSÃO CORRIGIDA

RIBEIRÃO PRETO - SP

2017 
Autorizo a reprodução e divulgação total ou parcial deste trabalho, por qualquer meio convencional ou eletrônico, para fins de estudo e pesquisa, desde que citada a fonte.

FRAZÃO, Natalia Francisca

Associação de Surdos de São Paulo: Identidade Coletiva e Lutas Sociais na cidade de São Paulo. Ribeirão Preto, 2017.

$141 \mathrm{p}$.

Dissertação de Mestrado, apresentada ao Programa de Pós-Graduação em Educação da Faculdade de Filosofia, Ciências, Letras da Universidade de Ribeirão Preto. Área de concentração: Educação.

Orientadora: Lodi, Ana Claudia Balieiro

1.Associação de Surdos de São Paulo 2. Ação Coletiva 3. Identidade Coletiva 4. Ator Coletivo 5. Movimentos sociais 
FRAZÃO, Natalia Francisca

Associação de Surdos de São Paulo: Identidade Coletiva e Lutas Sociais na cidade de São Paulo.

Dissertação apresentada ao Programa de Pós-Graduação em Educação da Faculdade de Filosofia, Ciências e Letras de Ribeirão Preto da Universidade de São Paulo para obtenção do título de Mestre em Educação.

Aprovado em:

Banca Examinadora

Prof. Dr. Instituição:

Julgamento: Assinatura:

Prof. Dr. Instituição:

Julgamento: Assinatura:

Prof. Dr. Instituição:

Julgamento: Assinatura: 


\section{AGRADECIMENTOS}

À Deus, com quem converso e reflito sobre as minhas ações e meus atos, sobre as minhas atitudes e minha consciência para entender o que, como e porquê posso melhorar coisas em mim mesma e nos outros.

Àqueles que me deram apoio e carinho e que tiveram muita compreensão e paciência em diversos momentos em que eu estive ausente. Graça a eles, consegui desenvolver o meu trabalho: Nilsa Neto Frazão (mãe), Nadir Abrantes Frazão (avó), Sebastião Neto Frazão (avô in memorian), Jorge Abrantes Frazão (tio), Margareth Frazão (tia), Dalva Helena dos Santos (tia), Sergio Wady Haddad (pai), Danilo Haddad (irmão), Serginho Haddad (irmão) e Pedro Haddad (irmão).

A quem me deu a mão em muitos momentos de ansiedade, cansaço e dúvida durante a trajetória do meu trabalho acadêmico: Raissa Tostes, André Matiolli, Vivian Randi, Fabio de Sá Silva, Dodora, Jade Moia, Andrea Cifuente e Casa 109.

A Elomena Almeida e Hanna Russo, primeiras pessoas que fiz amizade em Ribeirão Preto, que me apoiaram e me deram carinho, com quem pude desabafar para acalmar a minha mente e a minha alma tanto para o desenvolvimento de meu trabalho acadêmico árduo e quanto para a minha vida pessoal.

A Mario Pimentel, Marta Pimentel e Paulo Vieira, a quem admiro muito pela garra nas muitas lutas das e pelas comunidades surdas.

Aos grupos do Lalede, que depositaram sua confiança e contribuíram com meu trabalho de pesquisa: Hanna Russo, Eduardo Marinheiro, Samara Salvador, Veridiane Goulart, Ariele Matias, Adriana Mizukami, Melaine Muttão, Natalia Godoy, Aline Rezende e Otavio Costa.

Aos intérpretes de Libras que acompanharam a minha trajetória acadêmica: Angélica Gontijo, Michelle Sertório e Felipe Baléa.

À Ana Claudia Balieiro Lodi, uma gratidão por depositar sua confiança e por sua orientação (sei que foi um trabalho árduo, mas muito gratificante) para o desenvolvimento de minha dissertação de mestrado.

Aos Professores Doutores, Elmir de Almeida e Fábio Brito, pelas importantes contribuições na banca de qualificação deste trabalho.

À Coordenação do Programa de Pós-graduação em Educação, em especial Prof. Elmir de Almeida e a Profa Teise Garcia, pelo apoio dado para que fosse possível a presença de intérprete de Libras no Programa, fato que me possibilitou participar das diferentes atividades desenvolvidas no e pelo Programa.

À Coordenação de Aperfeiçoamento de Pessoal de Nível Superior (CAPES) pela concessão da bolsa de mestrado para a realização desta pesquisa. 


\section{Dedicatória}

Às comunidades surdas de São Paulo, com quem cresci, convivi e aprendi muito. Sem elas, nunca saberei o que, porque e como é um ser surdo. 


\section{RESUMO}

Esta dissertação teve como objetivo compreender o processo histórico das ações coletivas dos surdos da Associação de Surdos de São Paulo (ASSP), entre os anos de 1950 a 2011, período que compreende a fundação desta instituição e a criação das Escolas Municipais de Educação Bilíngue para Surdos (Emebs) na capital paulista. Neste contexto, o estudo buscou entender como surgiram as ações coletivas e como elas se mantiveram no decorrer do período investigado. Desenvolvida à luz do marco teórico de Alberto Melucci (1989, 1994, 2001, 2004), a pesquisa, de cunho qualitativo, teve como principais procedimentos para a coleta de dados, o estudo de artigos, dissertações, teses e vídeos que versavam sobre movimentos sociais; documentos da ASSP disponibilizados pelos seus dirigentes; e duas entrevistas narrativas com dois ex-presidentes da instituição. Pode-se observar que as ações coletivas que culminaram na fundação da ASSP tiveram início na década de 1950, a partir do interesse dos surdos em ter um espaço de convivência e de prática esportiva. Este espaço, em continua interação com outros atores sociais, acabou por propiciar o fortalecimento de uma identidade coletiva e a formação política de muitos surdos, fato que motivou outras ações coletivas, que foram determinantes para a fundação da Confederação Brasileira de Desportos de Surdos (CBDS) e da Federação Nacional de Educação e Integração dos Surdos (Feneis). Nesta rede de relações que foram sendo estabelecidas no decorrer da história, a ASSP teve um papel de destaque nos movimentos surdos que visaram o reconhecimento da Libras e a defesa pela educação bilíngue para surdos, assim como na transformação das antigas Escolas Municipais de Educação Especial do município de São Paulo em Escolas Municipais Bilíngues para Surdos (Emebs).

Palavras-chave: Associação de Surdos de São Paulo, ação coletiva, ator coletivo, identidade coletiva, movimentos sociais. 


\begin{abstract}
This research aimed to understand the historical process of collective actions of the deaf of the Deaf Association of São Paulo (ASSP), between the years 1950-2011, a period that includes the founding of this institution and the creation of the Municipal Bilingual Education Schools for the Deaf people (Emebs) in the state capital. In this context, the study sought to understand how these collective actions arose and how they were maintained during the investigated period. Developed based on the theoretical framework of Alberto Melucci $(1989,1994,2001,2004)$, the research, qualitative nature, had as main procedures for data collection, the study articles, dissertations, theses and videos that focused on social movements; ASSP documents made available by its directors; and two narrative interviews with two former presidents of the institution. It can be observed that the collective actions that culminated in the founding of ASSP began in the 1950s, based on the interest of the deaf in having a living space and sports practice. This space, in continuous interaction with other social actors, eventually facilitated the strengthening of a collective identity and the political formation of many deaf, which led to other collective actions that were decisive for the founding of the Brazilian Confederation of Deaf Sports (CBDS) and the National Federation of Education and Integration of the Deaf (Feneis). This network of relationships that have been established throughout history, the ASSP had a prominent role in deaf movements that aimed at the recognition of the Brazilian Sign Language and advocacy for bilingual education for the deaf, as well as the transformation of the old Special Education Public Schools in São Paulo in Bilingual Public Schools for the Deaf (Emebs).
\end{abstract}

Keywords: Deaf Association of São Paulo, collective action, collective actor, collective identity, social movements. 


\section{LISTA DE ABREVIATURAS E SIGLAS}

Abrasc - Associação Brasileira dos Surdo Cegos

AIDP - Ano Internacional das Pessoas Deficientes

ANC - Assembleia Nacional Constituinte

Arena - Aliança Renovadora Nacional

Asam - Asociação de Sordosmudos de Ayuda Mutua

ASSP - Associação de Surdos de São Paulo

ASMSP - Associação de Surdos-Mudos de São Paulo

Assucamp - Associação dos Surdos de Campinas

Asurj - Associação de Surdos de Rio de Janeiro

CBDS - Confederação Brasileira de Desportos de Surdos

Cenesp - Centro Nacional de Educação Especial

CIL - Centro de Interpretação de Libras

CISS - Comissão Internacional de Esporte de Surdos

CMDP - Conselho Municipal da Pessoa com Deficiência

CME - Conferência Municipal de Educação

CND - Conselho Nacional de Desportos

CNSS - Coordenadoria Nacional de Serviço Social

Conae - Conferência Nacional de Educação

Condicisur - Conferência dos Direitos e Cidadania dos Surdos do Estado de São Paulo

Copadis - Comissão Paulista para a Defesa dos Direitos dos Surdos

Copavi - Cooperativa Padre Vicente de Penido Burnier

Corde - Coordenadoria Nacional para a Integração da Pessoa Portadora de Deficiência

CSSM - Congregação Santista de Surdos-Mudos

CSS - Congregação Santista de Surdos

Cesb - Campanha para a Educação do Surdo Brasileiro

Derdic - Divisão de Educação e Reabilitação dos Distúrbios da Comunicação

Emeda - Escola Municipal de Educação Infantil para Deficientes Auditivos

Emee - Escola Municipal de Educação Especial

Emebs - Escola Municipal de Educação Bilíngue para Surdos

Enem - Exame Nacional de Ensino Médio

FMI - Fundo Monetário Internacional

Feneida - Federação Nacional de Educação e Integração de Deficiente Auditiva

Feneis - Federação Nacional de Educação e Integração dos Surdos

FCSM - Federação Carioca de Surdos Mudos

Fundeb - Fundo de Manutenção e Desenvolvimento da Educação Básica e da Valorização dos Profissionais de Educação

IBS - Instituto Benjamin Constant

Ibict - Instituto Brasileiro de Informação em Ciência e Tecnologia

Ideb - Índice de Desenvolvimento da Educação Básica

Iesp - Instituto Educacional São Paulo

Inep - Instituto Nacional de Estudos e Pesquisas Educacionais

Ines - Instituto Nacional de Educação de Surdos

LDB - Lei de Diretrizes e Bases da Educação

Libras - Língua Brasileira de Sinais

MDB - Movimento Democrático Brasileiro 
LSCB - Língua de Sinais das Cidades Brasileiras

MEC - Ministério de Educação e Cultura

NMS - Novos Movimentos Sociais

Nuppes - Núcleo de Pesquisas em Políticas Educacionais para Surdos

ONU - Organização das Nações Unidas

Paee - Plano de Atendimento à Educação Especial

PNE - Plano Nacional de Educação

Prolibras - Programa Nacional para a Certificação de Proficiência no Uso e Ensino da Língua Brasileira de Sinais - Libras e para a Certificação de Proficiência em Tradução e Interpretação da Libras/Língua

PUC-SP - Pontifícia Universidade Católica de São Paulo

SABs - Sociedade Amigos dos Bairros

SEE - Serviço de Educação Especial

Seesp - Secretaria de Educação Especial

SNI - Serviço Nacional de Informações

SSMDF - Sociedade dos Surdos-Mudos do Distrito Federal

UFRGS - Universidade Federal de Rio Grande do Sul

UNE - União Nacional de Estudantes

Unesco - Organização das Nações Unidas para a Educação, a Ciência e a Cultura

USP - Universidade de São Paulo 


\section{LISTA DE FOTOGRAFIAS}

Fotografia 1: Assembleia da Fundação da Associação de Surdos-Mudos de São Paulo

Fotografia 2: Diretores e Conselheiros Gerais em 1956

Fotografia 3: O primeiro campeonato de futebol entre jogadores de ASMSP e SSMDF em 1956.76

Fotografia 4: A mobilização de surdos na Avenida Paulista ....................................................... 119

Fotografia 5: Uma das faixas usadas pelos manifestantes ..................................................... 120

Fotografia 6: A comunidade surda no Conae em 2010 .......................................................... 122

Fotografia 7: As faixas das comunidades diante à abertura da Regional da Conae ..................... 122

\section{LISTA DE FIGURAS}

Figura 1: Capa de livro de Atas da Associação de Surdos-Mudos do Estado de São Paulo

Figura 2: Primeira página da primeira Ata da Associação de Surdos-Mudos de São Paulo 71

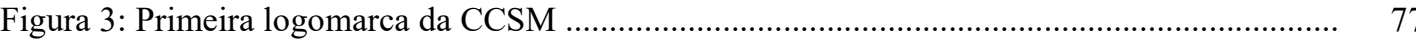

Figura 4: Brasão de Assucamp, desenhados por dois artistas surdos .......................................... 77

Figura 5: Associação de Surdos de Ribeirão Preto (ASRP) ............................................................

Figura 6: A logomarca de Comissão Internacional de Esporte de Surdos .................................... 88

Figura 7: Certificado de Comissão Internacional de Esporte de Surdos ....................................... 88

Figura 8: A Conferência dos Direitos e Cidadania dos Surdos de São Paulo ................................ 114

Figura 9: A capa da revista de Feneis sobre o movimento nacional de defesa das Escolas da Educação Bilíngue para Surdos na Brasília em 2011 ................................................................... 125

Figura 10: O discurso da líder e ativista surda, Patrícia Rezende .............................................. 125 


\section{SUMÁRIO}

INTRODUÇÃO

\section{CAPÍTULO I}

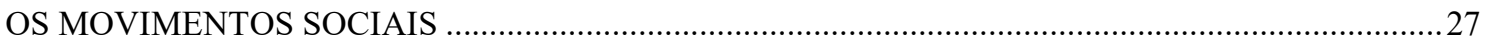

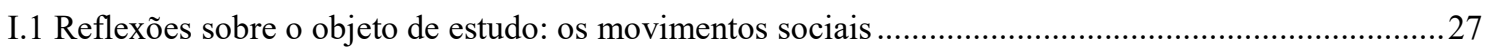

I.2 Processos históricos sobre os movimentos sociais e dos estudos sobre a temática ................................28

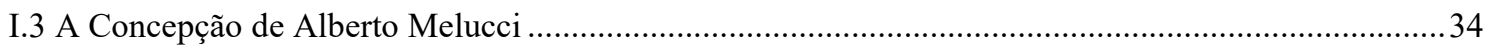

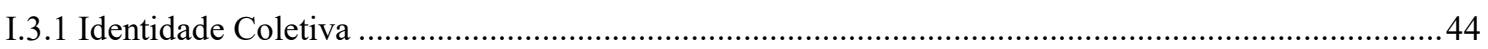

\section{CAPÍTULO II}

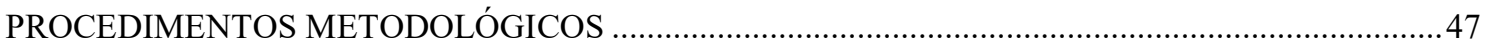

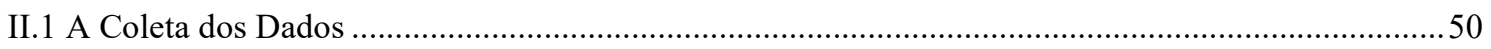

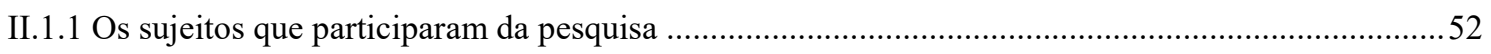

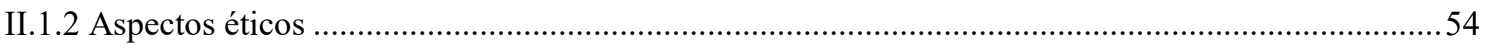

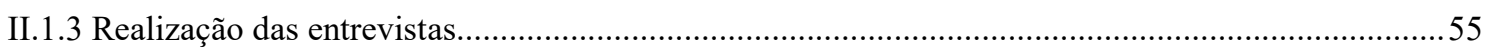

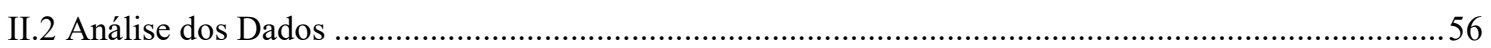

CAPÍTULO III

OS MOVIMENTOS SOCIAIS SURDOS DA CIDADE DE SÃO PAULO ..........................................59

III.1 A fundação da Associação de Surdos-Mudos de Surdos de São Paulo (ASMSP) ............................59

III.2 Parceria e apoio da ASMSP para a criação das Federações Desportivas de Surdos-Mudos ...............80

III.3 Apoio da ASMSP ao processo de criação da Confederação Brasileira Desportiva de Surdos (CBDS) e a luta contra a Federação Nacional de Educação e Integração dos Deficientes Auditivos (Feneida).........88

III. 4 A fundação de Confederação Brasileira Desportiva de Surdos (CBDS) e a criação da FENEIS......94

III. 5 A mudança de nome da ASMSP, sua parceria com a Feneis-SP e a luta dos surdos pelo reconhecimento da Libras

III. 6 A continuidade da luta dos surdos paulistas pelo reconhecimento da Libras e pela defesa da Educação Bilíngue para Surdos

III. 7 A continuidade do movimento em defesa da Educação Bilíngue para Surdos e a união entre ASSP, Feneis e escolas públicas para a criação das Escolas Municipais da Educação Bilíngue para Surdos (Emebs)

CAPÍTULO IV

CONSIDERAÇÕES FINAIS 


\section{INTRODUÇÃO}

Inicialmente, pareceu-me um pouco estranha a ideia de contar, mesmo que brevemente, a minha vida pessoal nesta introdução; achei que contar a história da minha vida era algo um pouco invasivo. Fiquei pensando, então, em redigir apenas aspectos das minhas experiências acadêmicas e escolha do tema de pesquisa. No entanto, nesse processo reflexivo, lembrei-me do sinal de discurso que usamos em nosso grupo de estudos - "língua viva", após discussões sobre a melhor forma de enunciar este conceito, em língua brasileira de sinais (Libras), quando em contexto de estudos bakhtinianos; lembrei-me de Bakhtin, autor que tenho tentado entender, quando ele afirma que a compreensão de um fato, de um objeto de estudo, de um autor, só é possível se estes forem olhados a partir do contexto histórico que os determinaram ou em que o texto foi escrito. Entendi que a compreensão deste texto também depende do conhecimento, mesmo que breve, do contexto histórico de quem o escreveu. Esta introdução, portanto, não é algo estranho, mas sim necessária.

Em minha segunda tentativa de redigi-la, pedi a minha mãe para que ela me contasse um pouco o que aconteceu quando soube que eu era surda. Ela já havia me contado esta história várias vezes, mas era preciso "ouvi-la" novamente, com atenção e com outros olhos, a fim de ser possível recortar trechos de minha vida que eu julgasse interessantes para este texto. No entanto, minha mãe decidiu não me falar nada. Apenas abriu seu netbook e começou a escrever. Enviou-me um e-mail. Confesso que tive que segurar minhas lágrimas ao saber o modo como muitas pessoas a trataram por ter engravidado ainda solteira; a forma cruel como três médicos lidaram com o fato de ela ter adquirido rubéola durante a gestação, recomendando o aborto por causa das possíveis sequelas que o bebê poderia ter. Mesmo assim ela decidiu por continuar com a gravidez. E após o meu nascimento, o posicionamento de outro médico, que minha mãe guarda em sua memória até hoje, que ao saber que eu era surda lhe disse: ela é surda, a surdez é total e dos dois ouvidos e não há nada que você possa fazer.

Compreendo que estávamos na segunda metade da década de 1980 e as informações relativas a importância de vacinas eram poucas e o preconceito contra 
mulheres grávidas solteiras ainda era grande. Mas estes fatos me levaram a refletir sobre o hoje. Apesar dos avanços da medicina, muitas mulheres grávidas ainda não possuem acesso a informações importantes sobre sua saúde e de seu filho, muitas mães ainda não possuem informações sobre o que é ter um bebê surdo. Convive-se ainda com a ignorância dos médicos de que os surdos devem ser compreendidos como pertencentes a um grupo cultural e linguístico minoritário e não como deficientes; com suas recomendações impositivas de que os bebês surdos devem usar aparelhos auditivos ou implantes cocleares e sofrerem um processo de reabilitação de fala; com a indicação de uma educação que não respeita as especificidades dos surdos, que, por ainda serem tratados como deficientes, é perpassada por perspectivas e discursos clínicos patológicos. Ignorase, portanto, que os surdos, como seres humanos e indivíduos, devem ser respeitados em sua diferença e compreendidos não pela ausência da audição, mas por sua especificidade linguística. Estas informações, acredito, poderiam ajudar as mães a tomarem a melhor decisão sobre o futuro de seus filhos surdos.

Após o enunciado do último médico, minha mãe entrou em desespero, mas com apoio de colegas e da assistente social de onde trabalhava, procurou uma fonoaudióloga especializada no atendimento de deficientes auditivos (como éramos chamados na época). A primeira tentativa deu-se na Divisão de Educação e Reabilitação dos Distúrbios da Comunicação (Derdic), onde foi indicado o uso de um aparelho auditivo caríssimo. A compra do aparelho só foi possível com o apoio dos colegas que se organizaram para a venda de rifas e "vaquinhas". Frequentei este atendimento por dois anos e, neste período, foi recomendado que minha mãe procurasse uma escola de surdos para minha maior socialização.

A primeira tentativa de escola deu-se em Osasco, cidade onde até hoje residimos. No entanto, minha mãe não gostou do que viu: alunos com várias diferenças misturadas em uma única sala de aula. Foi então, em companhia de minha avó, procurar escolas em São Paulo. Fui matriculada aos quatro anos de idade, em 1989, na Escola Municipal de Educação para Deficientes Auditivos (Emeda) Vera Lúcia Aparecida Ribeiro, em Pirituba, onde estudei da educação infantil à oitava série do ensino fundamental. Durante oito anos dependi da minha avó para ir à escola, pois, devido à distância, viajávamos por cerca de uma hora de ônibus de ida e mais uma de volta, além do caminho percorrido a pé. Somente nos três últimos anos do ensino fundamental tive minha primeira 
independência, pois podia ir à escola em companhia de um amigo de infância que estudava na mesma escola que eu. Nesta escola, agora chamada Escola Municipal de Educação Especial (Emee) Vera Lúcia Aparecida Ribeiro, pude me apropriar da língua de sinais, ter vários amigos surdos e aprender a ler e a escrever português. A leitura era, para minha mãe, algo muito importante para aprendizagem de vida. Conforme seu e-mail, "a leitura abriria o mundo para você e que através dos livros você ficaria integrada com o mundo e o mundo a você”. Foi esta história que a minha mãe contou.

Paralelamente à escola, frequentei, por quase dez anos, atendimento fonoaudiológico, para treinamento de fala e para apoio na aprendizagem da linguagem escrita do português. Para minha mãe, a língua de sinais era importante, mas ela queria me dar a oportunidade de aprender outras formas de comunicação para que eu tivesse escolha e liberdade de me comunicar com qualquer pessoa. "Fiz fono" até os meus 17 anos.

Em 2001, quando terminei o ensino fundamental, fui obrigada a mudar de escola. Fui matriculada, para cursar o ensino médio, em uma escola regular, particular, juntamente com uma amiga surda de infância, que também estudou comigo na Emee Vera Lúcia Aparecida Ribeiro. Na escola regular não havia intérprete de Libras, porque a Lei $n^{\circ} 10.436$, de 22 de abril de 2002, não havia sido sancionada. Nesta época, não havia muitas escolas que conheciam a língua dos surdos e, muito menos, reconheciam as comunidades surdas brasileiras como minorias culturais e linguísticas. Na minha nova escola, usavam-se apostilas como materiais didáticos e, neste momento, meus conhecimentos em língua portuguesa, mesmo básicos, auxiliaram-me na compreensão dos materiais e, portanto, no acompanhamento das aulas. Os professores sabiam que havia duas alunas surdas, mas falavam, sem nenhum cuidado, em sala de aula. Tudo era muito estranho e diferente para mim, mas não nego que aprendi algumas coisas neste espaço. Cursava ainda, paralelamente, cursos de arte e computação, que me ajudaram a compreender muitas coisas da vida fora da escola; e convivia com surdos com frequência, para realizar passeios e/ou encontrá-los nos pontos de encontro.

Ao término do ensino médio, percebi que para o ingresso na educação superior era necessária a realização de um curso pré-vestibular, porque não me sentia preparada para esta nova etapa; tinha vergonha por ter aprendido pouco nas aulas na escola regular; queria aprender mais. Encontrei um curso no qual, ao perceber que eu era surda, o 
coordenador iniciou nossa comunicação pela escrita, dizendo-me que havia intérprete de Libras naquele espaço e que ele me acompanharia durante as aulas. Fiquei desconfiada com a informação, porque, naquela época, eu não tinha a mínima ideia do que era um intérprete de Libras; para mim seria outra pessoa surda que sabia bem o conteúdo do ensino médio para me ensinar. Aceitei com má vontade. $\mathrm{O}$ coordenador pediu ainda para que eu voltasse no dia seguinte para conhecer o intérprete. Aceitei.

Ao conhecer o profissional e assistir as aulas com a mediação do intérprete senti que minha vida havia mudado completamente. Percebi a importância de sua presença para assegurar a acessibilidade na comunicação dos surdos, o porquê os surdos lutavam em defesa da Libras, os problemas em e de nossa educação e como se constituía o trabalho de um profissional intérprete de Libras - língua portuguesa. Tinha, agora, liberdade para expressar o que pensava, em Libras, e por intermédio da interpretação, compartilhar meus pensamentos com os ouvintes. Era uma sensação nova para mim, após dez anos me esforçando para falar e escrever, mesmo que fosse um pequeno texto em português, de forma compreensível aos ouvintes. Tinha consciência de que minha fala era (e ainda é) de difícil compreensão; sentia que, pela oralidade, minhas expressões poderiam ser comparadas a recados escritos em cartões ou bilhetes; não era algo meu.

Quando terminei o curso pré-vestibular estava apaixonada pela literatura brasileira. E embora desde pequena eu sonhasse em ser professora, decidi estudar outra área: escolhi graduar-me em Administração. Estudei em uma faculdade privada da cidade de São Paulo no período de 2007 a 2011 e, em seguida, fui trabalhar em escritórios de empresas, onde atuei durante quase seis anos. E embora nunca tenha gostado do que fazia, acreditava que com este trabalho poderia ter minha independência financeira.

Apesar de já existirem, nessa época, legislações que asseguravam os direitos dos surdos em terem interprete de Libras em todas as instituições públicas e privadas, tive que enfrentar muitos obstáculos no ingresso nessa faculdade: lá não havia intérpretes para me acompanhar no processo seletivo, na matrícula e em sala de aula; eu era a primeira e única graduanda surda daquela faculdade. Sentia que eu havia pulado de paraquedas em um território desconhecido, não sabia como e por onde começar a pedir ajuda. Resolvi solicitar, na secretaria de graduação, um intérprete. Para isso, contei com a ajuda de um amigo, o meu intérprete no período do curso pré-vestibular. Foi então agendada reunião para que eu fizesse a solicitação diretamente ao diretor. No dia marcado, meu amigo não 
pode me acompanhar e eu tive que enfrentar a reunião sozinha; a comunicação teve que ocorrer por meio da oralidade e da escrita. Percebi que o diretor não fazia a mínima ideia sobre o que era um intérprete de Libras e, nesse processo, ele percebeu que eu, realmente, precisaria do profissional.

Durante este processo, as aulas na graduação já tinham começado. Para tentar acompanhar os professores, entreguei a eles um texto escrito, no qual eu os orientava a falar devagar e de frente para mim (nunca de costas); mas percebi que alguns não compreendiam o porquê daquilo. Fiz, então, o sinal de "surdo" e oralizei, ao mesmo tempo, "sou surda"; eles se calaram e começaram as aulas. Alguns se esforçavam para ficar na minha frente para que eu fizesse leitura labial, outros me perguntavam a todo o momento se eu estava entendendo. Eu mentia. Dizia que estava compreendendo, para que eles não se incomodassem comigo. A verdade era a que eu não entendia quase nada do que me explicavam, acompanhava as aulas quando eles escreviam na lousa e por meio de resumos que uma amiga da classe fazia para mim. O intérprete demorou quase três meses para ser contratado, fato que mudou minhas condições educacionais.

De forma paralela, investia em outra formação visando mudar de profissão e realizar o sonho de trabalhar na educação. Assim, em 2011, fiz o exame de proficiência no uso e ensino de Libras e tentei ingressar no curso de graduação em Letras: Libras, mas não foi possível conciliar uma nova graduação e meus compromissos de trabalho e financeiros. Mas ainda me sentia fascinada pela educação. Comecei, então, a dar aulas de Libras para ouvintes, prática que desenvolvi por seis anos; e por um ano, trabalhei em uma Escola Municipal de Educação Bilíngue para Surdos (Emebs) na cidade de São Paulo como instrutora surda, auxiliando os professores regentes da educação infantil e ensino fundamental e ministrando oficinas de Libras para professores, funcionários e para a comunidade que vivia ao redor da escola. No decorrer deste período resolvi cursar mestrado em Educação na USP, fato que se concretizou apenas em 2015.

$\mathrm{Na}$ inscrição para os dois processos seletivos para cursar a pós-graduação em Educação na USP - campi Butantã e Ribeirão Preto, era solicitado, nos editais, o envio de um laudo médico e de uma audiometria para a comprovação de que eu era surda; imaginei que com isso estaria assegurado um intérprete de Libras tanto para o período de seleção quanto para as atividades do curso. Mas, novamente, tive que enfrentar a falta do profissional, visto que somente houve intérprete de Libras nos exames do processo 
seletivo do campus Butantã; não havia a presença deste profissional no campus Ribeirão Preto. Neste, tive que contar com o auxílio de uma professora, Ana Claudia Balieiro Lodi (que seria a minha futura orientadora), que possuía uma boa fluência de Libras, para interpretar para mim tanto as instruções da prova como a entrevista de ingresso.

Estava torcendo muito para passar na prova neste campus, pelas linhas de pesquisa, pela existência do grupo de pesquisa e estudo a respeito da educação bilíngue para surdos coordenado pela orientadora Ana Claudia Lodi, cujos artigos e livros eu já tinha lido; sentia-me mais segura com este campo do conhecimento. Fui, então, aprovada (tive muita sorte, parece que o Deus me mostrou "a hora certa" para passar neste exame). No entanto, ao ingressar no curso de mestrado, outros desafios tiveram que ser por mim vencidos. O primeiro deles foi a falta de intérprete de Libras, profissional para mediar minha comunicação em situações de secretaria, nas disciplinas e no grupo de estudos que Ana Claudia Lodi coordena. Por sorte, havia alguns colegas que sabiam um pouco de Libras e, em outros espaços que a Profa. Ana Lodi não podia estar presente, eu podia contar com eles para me apoiarem.

Alguns meses após o início do mestrado, consegui uma bolsa de estudos, graças à compreensão e esforços da coordenação do Programa de Pós-graduação juntamente com minha orientadora e, com esta bolsa, inicialmente, pagava o intérprete. Mas não estava certo. Assim entrei com uma ação junto ao Ministério Público contra a USP; em alguns meses a Universidade assinou um convênio com a Federação Nacional de Educação e Integração dos Surdos (Feneis) e eu pude ter um intérprete nas aulas, no grupo de estudos e em eventos na Universidade.

Outros dois grandes obstáculos ainda precisaram ser enfrentados no início e no decorrer dos meus estudos na pós-graduação. O primeiro deles era escrever uma dissertação, conseguir transmitir minhas reflexões em uma língua que não é a minha em língua portuguesa. Sentia que minha escrita era suficiente para textos "informais", mas não tinha conhecimento de como faria com a escrita acadêmica. Por este motivo, acredito ser importante registrar aqui como foi o processo de escrita desta dissertação de mestrado, visto que não é possível pensar de forma generalizada acerca do processo da escrita de acadêmicos surdos, pois há surdos que possuem um bom conhecimento da escrita da língua portuguesa enquanto outros não. 
Esta diferença, no meu modo de entender, diz respeito à vivência de cada um, ao contato com bens culturais escritos no decorrer de cada história de vida, às motivações dos familiares e aos processos educacionais que perpassaram cada trajetória até o ingresso na pós-graduação. No entanto, o que há de comum nessas experiências é a presença de marcas da Libras em todo e qualquer texto escrito em português por surdos, da mesma forma como acontece com estrangeiros e com outras minorias linguísticas e culturais quando na escrita de outra língua que não seja a sua primeira língua.

Nesse transito entre línguas que os surdos vivem, a presença do orientador(a) é imprescindível para a construção do trabalho de pesquisa, observando e orientando sobre as diferentes formas de apropriação dos conhecimentos (constituídos socialmente em um diálogo com outros e com ele próprio) a fim de ser possível que o mestrando(a) tenha uma compreensão ativa do seu objeto de pesquisa para o desenvolvimento de seu estudo, no difícil processo de transformar-se pesquisador. Neste contexto dialogo com Bakhtin $(2011,2014)$ sobre a importância de se compreender a criação de uma obra não como um mero artefato, como um dado acabado, mas como um objeto estético, construído por um autor-criador em suas múltiplas relações com outros (este outro que, muitas vezes, é o próprio pesquisador), responsáveis por dar acabamento tanto ao texto como ao próprio autor. Nesse sentido, a participação do grupo de estudos, mas em especial da presença de minha orientadora no processo de construção deste estudo foram de fundamental importância. São, portanto, vozes que também se fazem presentes neste trabalho.

Lembro-me que para a redação dos capítulos que compõe esta dissertação, foram necessárias muitas discussões teóricas, em Libras, com minha orientadora e nos grupos que ela coordena: de estudos bakhtinianos e de orientação. Mas como não havia como fugir da escrita, enviei um primeiro texto por e-mail para ela fazer comentários. Fiquei assustada com a quantidade de comentários (muitos deles eram "não entendi", "sem sentido", "frases soltas") e com as marcas coloridas do corretor do word. Cheguei a pensar que não saberia/conseguiria escrever o texto e, em alguns momentos, confesso, senti vontade de desistir. Mas com o passar do tempo, compreendi a importância daqueles comentários: era uma forma de eu aprimorar meu discurso, as escolhas das palavras e obter um maior adensamento da temática a fim de construir um texto compreensível não apenas para mim, mas também aos outros. Foi a partir deles que eu, pouco a pouco, melhorava minha escrita acadêmica. 
Em outros momentos, no entanto, apesar de ter refletido e compreendido muitos conceitos teóricos e ser capaz de discuti-los, com propriedade em Libras, sentia muita dificuldade em explicá-los, de maneira clara, em português. Era necessário, portanto, nestas situações, a presença física da minha orientadora para me auxiliar na escrita: sentávamos juntas na mesa do computador, eu explicava para ela, em Libras, o que eu gostaria de ter escrito e ela fazia a tradução para português, preocupando-se, sempre, em retornar o texto para mim a fim de que o discurso escrito fosse o mais próximo possível daquele enunciado em Libras.

Mas nem sempre o que eu achava estar claro conceitualmente era para os outros. Nestes momentos, tornavam-se necessárias mais conversas em Libras, a fim de que eu percebesse que algumas reflexões ainda não tinham sentido ou estavam sendo apresentadas de forma superficial. Nestes momentos conversava comigo mesma em Libras: como eu posso ter escrito/pensado desse jeito? E gradativamente, com o auxílio das orientações e dos grupos fui compreendendo tratar-se de um processo necessário de aprendizagem, tanto no que se refere ao desenvolvimento de uma pesquisa/tornar-se pesquisadora, quanto para o meu maior conhecimento da escrita acadêmica. Lembravame, novamente, das discussões de Bakhtin e da importância dos outros a fim de ser dada completude ao texto.

Recordo-me ainda de outra orientação que era dada no grupo e que, no início não fazia sentido para mim: quando terminar a escrita de um capítulo, deixe o texto "dormir" por alguns poucos dias, volte a ele e veja se ele está claro ou se o que está escrito é exatamente aquilo que gostaria de ter escrito. Percebi que era quase sempre necessário reescrever! E neste longo e produtivo processo de escrita, neste trânsito e diálogo entre línguas, com diversos outros e comigo mesma, a redação desta dissertação tornou-se possível.

O segundo desafio que tive que enfrentar diz respeito à escolha de um novo tema de pesquisa, já que meu projeto inicial não era viável de ser desenvolvido. Naquele momento, meu projeto era investigar a relação pedagógica entre instrutor e alunos surdos, em atividades que envolvessem a cultura e a identidade surda em uma das Emebs da cidade de São Paulo. Após ser questionada, por minha orientadora, sobre o que eu entendia por cultura e identidade surda, percebi que eu não dominava os conceitos, pois mesmo ciente de que a resposta iria depender da perspectiva teórica adotada, não 
conseguia explicá-los sem ser superficialmente; tinha um discurso pronto, mas nunca havia refletido sobre estes conceitos, mesmo após muitas leituras. Decidi então, mudar de tema.

No decorrer do semestre, minha orientadora mostrou-me um livro intitulado Historia Ilustrada de La Comunidad Sorda (GONZÁLEZ, 2013), escrito e ilustrado por um surdo uruguaio, no qual ele relatava, em desenhos e pouca escrita, a história dos surdos. Fiquei impressionada com os maravilhosos detalhes presentes nos desenhos, que me ajudaram a compreender claramente a longa história de lutas dos surdos. Surgiramme algumas lembranças de minha experiência de trabalho como instrutora de Libras na Emebs, pois em uma atividade desenvolvida na sala de aula de Libras, fui solicitada pela professora regente para esclarecer algumas partes da história dos surdos na antiguidade, idade média, moderna e contemporânea, pois alguns alunos não tinham compreendido a explicação da professora. Nesse momento, senti muita dificuldade para explicar o que tinha sido pedido, pois não tinha me preparado para isso.

Percebi a minha ingenuidade em pensar que saber Libras era o suficiente, que por seu intermédio todos os alunos aprenderiam da mesma forma e, pior, da mesma maneira como eu aprendi quando estudava na Emee, período em que não havia instrutores e/ou professores surdos na escola e os professores ouvintes nada nos contavam sobre a história dos surdos; não tínhamos a mínima ideia sobre as lutas que os surdos estavam travando fora dos muros da escola, lutas estas que diziam respeito também a nós, pela melhoria de nossa educação. Senti que a experiência de ser aluna é muito diferente de ser instrutora, que precisa estar preparada para os desafios que ocorrem em sala de aula. Enquanto lembrava minhas experiências e refletia sobre elas, fui, ao mesmo tempo, compreendendo que cada um possui sua história e contexto de vida, que ninguém é igual e, portanto, que posso ter tido falhas quando atuava como instrutora de Libras; no entanto aproveitava (e ainda aproveito) a chance para refletir sobre minha postura profissional e acadêmica. Espero, em trabalhos futuros como educadora, caso tenha oportunidade, realizar algo melhor, assumindo com responsabilidade as possibilidades e limites da prática. O mesmo vale em relação à pesquisa.

Mas continuava a folhear aquele livro maravilhoso e, novamente, me veio outra lembrança: ainda na Emebs tive a oportunidade de conversar com algumas professoras regentes sobre a importância de contar, aos alunos, a história da Associação de Surdos de 
São Paulo (ASSP) e da Feneis; ao mesmo tempo ficava receosa de me pedirem para fazer isso ou de ajudá-las na preparação das aulas, porque sabia muito pouco sobre esta história, meu conhecimento sobre estas importantes instituições para os surdos era superficial. Por este motivo, recorri ao material didático oferecido pela Secretaria Municipal de Educação de São Paulo e fiquei espantada ao descobrir que estas histórias apareciam nos livros de forma bastante simplificada, acrescidas de duas entrevistas curtas de dois surdos que participaram dessas instituições.

Comecei, então, a me questionar: será que os surdos conhecem a trajetória de lutas dos surdos como retratada, de forma aprofundada, por aquele ilustrador? Será que os alunos das Emebs possuem a oportunidade de conhecê-la e de refletir, criticamente, sobre a importância das lutas dos surdos para nossas comunidades?

Conversei com minha orientadora sobre as minhas lembranças e, juntas, começamos a refletir que minhas inquietações poderiam transformar-se em objeto de pesquisa. Queria investigar agora a história dos surdos, se não no Brasil, no Estado de São Paulo. Ela passou a me fazer algumas perguntas para minha reflexão (novas descobertas): quanto tempo para pesquisar a trajetória de lutas dos surdos no Estado de São Paulo? Ri envergonhada e respondi que talvez precisasse de dez ou vinte anos para concluir o trabalho. Mas, e se eu focalizasse apenas a cidade de São Paulo? Não conhecia trabalhos voltados a este tema. Ela me fez, então, outra pergunta: qual período eu gostaria de investigar? Não soube responder. Pedi-lhe um tempo para que eu fizesse uma pesquisa na internet sobre o que havia sobre as lutas dos surdos em São Paulo. Com surpresa percebi que as únicas informações existentes eram sobre a criação das primeiras escolas de surdos em São Paulo; nada indicava os movimentos surdos na cidade. Eu gostaria de estudar e compreender o processo para a fundação da ASSP, mas não sabia dizer até qual ano.

Ela, então, me fez a última pergunta: por quais razões os surdos paulistanos lutaram na última década? Pela educação bilíngue, para que as Emees reconhecessem a Libras como língua a ser usada em todo o processo educacional dos surdos, para que não se mantivesse mais o discurso da educação especial do passado, para que os surdos não fossem incluídos nas escolas de ouvintes, para que a prefeitura transformasse, portanto, as Emees em Emebs! Nesta luta eu estive presente! Participei do Seminário em Defesa da Educação Bilíngue para Surdos realizado na Assembleia Legislativa. Foi um dia 
marcante em minha vida. Faltei no trabalho e nunca me arrependi disso, lutei e apoiei a minha comunidade surda, caminhei com velas acesas juntos aos líderes surdos, alunos, pais e professores a fim de mostrar o porquê estávamos lutando e como compreendemos que deva se dar a educação dos surdos. Decidi, então, que o período seria de 1950 a 2011 - de quando teve início os movimentos para a fundação da ASSP até o reconhecimento, na capital do estado, das Emebs.

De comum acordo sobre a temática, minha orientadora aproveitou e me fez mais uma pergunta. Para você, o que são movimentos sociais? Na hora veio à minha cabeça que movimento social era a única experiência que eu tinha tido e conhecia: sair à rua e lutar, protestar, brigar por aquilo que acreditamos. Mas me pareceu, novamente, muito simplista. Era hora de eu parar e começar a estudar de verdade. O tema eu já tinha!

Esta dissertação, portanto, teve como objetivo compreender o processo histórico das ações coletivas dos surdos da Associação de Surdos de São Paulo (ASSP), entre os anos de 1950 a 2011, período que compreende a fundação desta instituição e a criação das Escolas Municipais de Educação Bilíngue para Surdos (Emebs) na capital paulista. Nesse contexto, o estudo procurou responder as seguintes questões de pesquisa: como surgiram as ações coletivas dos surdos que possibilitaram a fundação da ASSP? Como os surdos mantiveram suas ações coletivas no decorrer da história a fim de garantirem seu direito às escolas bilíngues para surdos?

Para a construção deste texto foram tecidos quatro capítulos. No primeiro foi apresentada uma breve história dos estudos sobre movimentos sociais e os principais conceitos da concepção teórica de Alberto Melucci, escolhida para sustentar esta pesquisa, por considerar a lógica dos atores coletivos, as relações sociais no interior dos movimentos para o delineamento das ações coletivas, sem desconsiderar o contexto social, político e ideológico no qual estes movimentos ocorrem. No segundo capítulo, foram descritos os procedimentos metodológicos da pesquisa; no terceiro, foram apresentados e analisados os dados da pesquisa e no quarto e último capítulo, foram tecidas algumas considerações. Na continuidade destes capítulos, foram apresentadas as referências bibliográficas usadas na construção deste texto. 


\section{CAPÍTULO I}

\section{OS MOVIMENTOS SOCIAIS}

\section{I.1 Reflexões sobre o objeto de estudo: os movimentos sociais}

O que são movimentos sociais? Esta questão é comum a quem começa a investigar o tema, ver ou participar de movimentos sociais ou ouvir ou ler textos de outros que pesquisaram sobre a temática. Possivelmente, a primeira coisa que se busca, ao se iniciar os estudos acerca dos movimentos sociais, é a definição deste conceito; no entanto, qualquer definição de movimentos sociais, mostra-se uma falácia, já que um conceito não pode ser tomado como verdade absoluta, visto que todo e qualquer conceito é polissêmico (BAKHTIN, 2009). Seu sentido depende das distintas maneiras de se conceber os movimentos sociais, fato que terá implicações nos objetivos que sustentam os diferentes estudos.

Apesar de não haver uma compreensão única sobre os movimentos sociais, Alexander (1998), Gohn (1997) e Picolotto (2007) concordam que, por intermédio destes estudos, tornou-se possível perceber as influências destes movimentos para a compreensão de determinadas mudanças sociais. Segundo Alexander (1998, p. 20), “os movimentos sociais emergiram como fenômenos importantes e organizados, e tornou-se possível, pela primeira vez, uma mudança social organizada”. Nesse sentido, pode-se dizer que, de certo modo, as mudanças sociais são de responsabilidade dos movimentos sociais.

Essa percepção do papel dos movimentos sociais pode ser feita pelo próprio investigador na presença das ações coletivas ou pode ser um momento de estudo em que o investigador passa a se interrogar como e por quais motivos os determinados movimentos sociais tiveram início (PICOLOTTO, 2007). No entanto, ao se olhar os diferentes estudos realizados, é possível observar neles elementos que podem ou não serem aproximados, processo determinado, principalmente, pelo período da história estudado e pelo arcabouço teórico que os sustentam. 
Por este motivo, optou-se por uma breve apresentação histórica das perspectivas existentes sobre movimentos sociais, a fim de inscrever a presente pesquisa naquela que melhor responde aos objetivos deste trabalho, a saber, a concepção da teoria da ação coletiva e da identidade coletiva de Alberto Melucci.

\section{I.2 Processos históricos sobre os movimentos sociais e dos estudos sobre a temática}

Considerando que os movimentos sociais estão inter-relacionados a transformações sociais, sua existência pode ser sentida desde a Antiguidade. Segundo Miranda, Castilho e Cardoso (2009), reconhece-se, nesta época, os movimentos escravos e religiosos; na Idade Média, os movimentos camponeses contra o poder feudal; na Idade Moderna, a revolução industrial e sua transição para o modelo capitalista de produção; e na Idade Contemporânea, os movimentos operários. Pode-se dizer, portanto, que os movimentos sociais se organizaram quando havia conflitos de poder entre os homens.

Entretanto, a maioria dos investigadores (ALEXANDER, 1998; PICOLOTTO, 2007; LIMA, 2008), na ciência social ocidental, aponta que, supostamente, os primeiros estudos sobre o tema visaram compreender os movimentos sociais ocorridos nos séculos XVIII e XIX na França e Rússia, respectivamente. Estes movimentos revolucionários, caracterizaram-se pela coerção e pela violência como tática de luta, uma forma de assegurar o controle e defender-se contra ações antirevolucionárias por aqueles que recém conquistavam o poder (PICOLOTTO, 2007). Destaca-se, como exemplos desses movimentos, a Tomada da Bastilha (Revolução Francesa) e do Palácio de Inverno (Revolução Russa).

Reconhece-se, no entanto, Karl Marx como o primeiro e mais importante ideólogo dos movimentos revolucionários, distinguido por afirmar o modelo clássico dos movimentos sociais. Sua forma de pensar contribuiu, de forma significativa, para a "construção de teorias explicativas dos movimentos sociais e também sua influência na orientação da prática dos movimentos" (PICOLOTTO, 2007, p.157). Marx opunha-se à exploração da força de trabalho dos proletários no contexto da sociedade industrial e à desigual distribuição de bens e serviços instituída pelo mundo capitalista. Para ele, as mudanças sociais só seriam alcançadas pela insurreição das massas ou classes dominadas, que teriam força agressiva suficiente para tirar e controlar o poder do Estado e, portanto, 
da classe dominante. Objetivava-se assim, uma nova organização social com vistas a se obter a distribuição equitativa de bens e serviços. Nesse sentido, a perspectiva dos movimentos revolucionários de base marxista, por partir do conceito de práxis social, visava articular "a atividade prática (ação do movimento) e a teórica (concepção do movimento) num conjunto unitário, voltando-se para o objetivo da transformação social” (PICOLOTTO, 2007, p. 157-158).

Gohn (1997), ao examinar o trabalho de Marx, reconhece nele dois momentos distintos, que inspiraram duas correntes de pensamento: a ortodoxa e a heterodoxa. A primeira, na qual se inscreve o modelo clássico, tem como base os estudos marxistas sobre o desenvolvimento do capital e, portanto, neles há o privilégio dos "fatores econômicos e macroestruturais da sociedade" (PICOLOTTO, 2007, p.159). Reconhece-se que, em função do arcabouço teórico que sustenta estes estudos, as estruturas sociais (principalmente a econômica) são analisadas e consideradas como determinantes da ação humana. Subestimam-se, conforme expôs Picolotto (2007, p. 160), "as contribuições culturais e a ação criativa dos indivíduos na formação dos movimentos sociais". Nesse sentido, Gohn (1997) entende que os estudos clássicos se concentram no saber o porquê surgem os movimentos, mas não podem explicar como eles surgem e como eles se mantêm ao longo do tempo.

A corrente heterodoxa surge a partir de críticas aos estudos de tradição marxista ortodoxa, havendo o abandono, em diferentes graus, dos pressupostos que lhes deram origem, para a construção de outras "interpretações que propõe novos referenciais para entender os novos fenômenos políticos e sociais" (PICOLOTTO, 2007, p. 160). Tem-se início, conforme expôs o autor, os estudos de tradição histórica-humanista, que passaram, pouco a pouco, a atenuar o peso antes dado às determinações estruturais, por meio da filiação às perspectivas teóricas que visavam atribuir "maior autonomia de ação aos atores sociais" (p.160).

Esses estudos, conhecidos como "Novos Movimentos Sociais" (NMS), passaram a ser, academicamente reconhecidos, a partir da década de 1960, muito embora trabalhos, nesta nova perspectiva, tenham se iniciado já nas primeiras décadas do século XX. Os estudos dos NMS, segundo Gohn (1997), não olham mais os movimentos a partir de classes sociais (nível macroestrutural), mas sim voltam seu olhar para os movimentos sociais buscando compreender as relações intersubjetivas (nível da microestrutura social). 
O foco torna-se os atores sociais, entendidos como um coletivo de múltiplos interesses, que luta e critica os progressos da modernidade no contexto social em que vivem (PICOLOTTO, 2007).

Para Gohn (1997), os estudos dos NMS podem também ser caracterizados pela centralidade que a política adquire na análise dos movimentos; pela construção de um modelo teórico que tem na cultura sua base; pela eliminação da concepção de sujeito específico, predeterminado, constituído pelas relações partidárias; e pela análise dos atores sociais, que pode ser realizada a partir de duas perspectivas: "por suas ações coletivas e pela identidade coletiva criada no processo" (p.123).

A política é redefinida nos estudos dos NMS, passando a ser compreendida como "uma dimensão da vida social, abarcando todas as práticas sociais" (GOHN, 1997, p. 123). Distancia-se assim, de um olhar que a compreendia de maneira hierárquica e determinista. Para Goulart (1993), quando os atores sociais desenvolvem consciência política, procuram um espaço político para se posicionarem, exprimirem suas opiniões e suas percepções sobre a forma como o Estado trata a sociedade, principalmente no que diz respeito às necessidades, interesses e carências dos cidadãos individuais ou coletivos. Enfatiza-se, desse modo, no que se refere à dimensão política, as relações microssociais e culturais (GOHN, 1997).

A cultura, segundo Gohn (1997), é compreendida, nos estudos dos movimentos sociais, como ideologia. Entende-se que esta compreensão ocorra porque alguns estudos ainda têm como base a teoria marxista, na qual o conceito de ideologia está intrinsecamente relacionado com o de consciência de classe. No entanto, como questões voltadas à diferença de classe perderam relevância nos novos movimentos sociais, a autora conclui que "a categoria de cultura foi apropriada e transformada no decorrer de sua utilização nos NMS" (p.122) constituindo-se, na atualidade, um conceito central para estes estudos.

No que diz respeito à concepção de sujeito, os NMS compreendem que este não pode mais ser considerado como "redutor da humanidade" (GOHN, 1997, p. 122), alguém predeterminado e criado pelas contradições do capitalismo, formado por ações partidárias. Surge, para os NMS, um sujeito que passa a ser concebido como um coletivo difuso e não hierarquizado, que "luta contra discriminações de acesso aos bens da modernidade, e ao mesmo tempo, crítico de seus efeitos nocivos, a partir da 
fundamentação de suas ações em valores tradicionais, solidários, comunitários" (GOHN, 1997, p. 122 - 123). A centralidade, portanto, deixa de estar em sujeitos específicos e volta-se aos participantes das ações coletivas, que passam a ser concebidos como atores sociais.

A respeito dos atores sociais, de acordo com Gohn (1997) e Picolotto (2007), a partir da década de 1960, surgem duas correntes europeias que passaram a analisar os movimentos sociais focalizando os atores coletivos. Como representantes da primeira corrente, os autores discutem os trabalhos de Touraine, desenvolvidos na década de 1970, nos quais o autor analisa os novos movimentos sociais a partir da concepção de ação social e cultural dos atores coletivos, e de Melucci, que ao estudar os NMS, desenvolve a teoria da ação coletiva, que visa compreender como ocorre a organização da ação por atores coletivos. $\mathrm{Na}$ segunda corrente, cujos trabalhos se inscrevem na perspectiva neomarxista, Gohn (1997) e Picolotto (2007) discutiram os estudos de outros dois investigadores: Offe, que buscou compreender os movimentos sociais a partir da conjuntura sociopolítica, e Castells, que voltou seu olhar para os movimentos sociais urbanos, enfatizando as práticas dos atores sociais.

Segundo discutiu Picolotto (2007), Touraine, na década de 1970, compreendia os movimentos sociais como uma "ação conflitante de agentes de classes sociais lutando pelo controle do sistema de ação histórica" (TOURAINE, 1977 apud PICOLOTTO, 2007, p.161), sistema este, social e cultural, que impulsiona o desenvolvimento da sociedade. No início dos anos 2000, seus estudos buscaram compreender a relação entre sujeitos, movimentos sociais e Estado, na medida em que, para ele, os sujeitos exercem um importante papel para o processo democrático. Touraine compreendia que a constituição da subjetividade não se dá individualmente; ela é um processo que ocorre na relação com outros pertencentes à mesma classe/grupo social. É a partir desta forma de compreender o sujeito que ele estabeleceu a relação entre subjetividade e movimentos sociais. Para Touraine, os movimentos sociais

Devem servir de mediadores entre o sujeito e o Estado. Os movimentos sociais têm o papel de desenvolverem sujeitos livres e autônomos, por um lado, e construírem as mediações necessárias entre o Estado e os indivíduos, por outro. Ou seja, é fundamentalmente de responsabilidade destes a construção da democracia e a garantia do direito à diferença (PICOLOTTO, 2007, p.162). 
Nesse sentido, para Picolotto (2007), Touraine defendia que por meio dos movimentos sociais, os problemas da fragmentação do sujeito e da modernidade poderiam ser resolvidos, ao questionarem os modelos culturais e de desenvolvimento, atuando, desse modo, no conflito social central.

Melucci (1989), por sua vez, critica as teorias estruturais adotadas nos anos 70, que, por buscarem analisar os sistemas, acabaram por explicar, apenas, o porquê dos movimentos se estabelecerem e manterem sua estrutura, desconsiderando, portanto, a ação coletiva e seus atores. De forma contrária, Melucci (1989) defende que as ações sociais, ao invés de serem analisadas a partir das contradições estruturais, devem ser consideradas "como uma interação de objetivos, recursos e obstáculos, como uma orientação intencional que é estabelecida dentro de um sistema de oportunidades e coerções” (p. 52). Nesse sentido, os estudos do autor buscam compreender como os atores organizam as ações sociais, sem ignorar o porquê acontece essa ação a partir de um dado contexto social, histórico, cultural, político e ideológico.

Segundo Gohn (1997), Offe, ao analisar os movimentos sociais articulando os campos sociocultural e político de forma estrutural, visou entender as posições politicoideológicas dos atores sociais, os modos como eles atuam politicamente e como se organizam a fim de obter "uma resposta racional a um conjunto específico de problemas da conjuntura sociopolítica" (OFFE, 1988 apud GOHN, 1997, p. 165). Para Gohn (1997), este investigador alemão não procurou estudar apenas os membros do grupo coletivo, mas sim a relação que eles estabelecem com outros na estrutura social, ou seja, com uma ampla comunidade de pessoas, e como expressam sua vontade política a respeito dos problemas sociais da vida cotidiana.

Conforme discutiram Goss e Prudêncio (2004), Offe compreende que os posicionamentos políticos e as ações empreendidas pelos atores, por meio dos movimentos sociais, acabam interferindo nas políticas do Estado, pressionando-o para a resolução de problemas sociais existentes ou ocorridos na sociedade. Nesse sentido, os movimentos sociais, para Offe, tornam-se "elementos novos dentro de uma nova ordem que se estaria criando. Eles reivindicam seu reconhecimento como interlocutores válidos, atuam na esfera pública e privada. Objetivam a interferência em políticas do Estado e em hábitos e valores da sociedade" (GOHN, 1997, p. 167). 
Os estudos de Castells, por sua vez, centram-se na análise dos movimentos sociais urbanos, especialmente no exame dos diferentes papéis e práticas que os atores sociais adotam em sua luta por melhorias urbanas. Para Gohn (1997), apesar de ser considerado neomarxista, Castells não considera os movimentos sociais como ligados a lutas de classes, mas sim como uma forma de resistência ao poder do Estado. Nesse sentido, para o autor, os movimentos sociais podem ser definidos como "práticas coletivas conscientes originárias de problemas urbanos, capazes de produzir mudanças qualitativas no sistema urbano, na cultura local e nas instituições políticas em contradição com os interesses sociais dominantes institucionalizados" (GOHN, 1997, p. 192). Castells compreende ainda que existem diferentes formas de organização das ações coletivas, como por exemplo, os movimentos sindicais relacionados com questões de consumo coletivo (melhoria de infraestrutura urbana ou ao uso da terra); os comunitários, que se voltam para a busca e a manutenção de uma identidade cultural local (com base étnica ou de construção histórica); e os de cidadãos, que visam o "aumento de poder local, descentralização das áreas de vizinhança e auto-administração urbana" (GOHN, 1997, p. 192).

A partir dos estudos das distintas concepções sobre a ação coletiva empreendida pelos atores sociais, chamou a atenção à forma pela qual os investigadores dos novos movimentos sociais compreendem os atores coletivos, responsabilizando-os pela tentativa de criar formas de pressionar as mudanças e as transformações das estruturas sociais. Observou-se ainda que, à exceção de Melucci, os autores focalizam suas análises nas relações estabelecidas entre os atores coletivos e os sistemas sociais no nível macrossocial, negligenciando, em suas explicações, como se estabelecem as relações entre os atores no interior do movimento social.

Melucci (2001), de forma contrária, busca, em seus estudos, compreender a totalidade do processo da ação coletiva, ou seja, as formas como os atores sociais se organizam e mantem-se unidos (relações internas), bem como a relação que determinado movimento estabelece com o contexto social mais amplo. Desse modo, pode-se dizer que o objetivo de suas análises se volta para "a interação entre as motivações individuais dos atores - ponto de vista subjetivo - e as condições estruturais do sistema - ponto de vista objetivo" (BRITO, 2013, p.60). Nesse sentido, para Melucci (2001), os atores coletivos 
tomam a ação coletiva para confrontar ou pressionar os "membros" das estruturas da sociedade e do Estado, a partir de situações do contexto da vida cotidiana.

Nesse sentido, compreendeu-se que a teoria da ação e a perspectiva da identidade coletiva de Melucci $(1989,1994,2001,2004)$ tornam-se importantes para se refletir e discutir o objeto desta pesquisa: os movimentos sociais surdos na cidade de São Paulo no período de 1950 a 2011. Por este motivo, a seção abaixo será dedicada para a discussão dos aspectos teóricos principais discutidos por este autor.

\title{
I.3 A Concepção de Alberto Melucci
}

Brito (2013), em seu estudo, comenta que apesar dos estudos de Melucci estarem na corrente de Novos Movimentos Sociais, este sociólogo, de origem italiana, acha estranho o termo "novo" qualificando os movimentos sociais. Para Melucci (2001), não existem movimentos "novos", já que eles estão sempre em transformação, da mesma forma que a sociedade não é estática. Para ele, qualquer estudo que se propõe analisar movimentos sociais deve fazê-lo em relação ao contexto histórico, social e cultural no qual eles se inserem, considerando, ainda, que o que é novo hoje, amanhã já não é mais, e que os significados e as ações dos movimentos sociais estão sempre em processo, são mutáveis e flexíveis, nunca fixos e permanentes. Assim como:

\begin{abstract}
Os chamados "novos movimentos sociais" nunca são somente "novos", mas são sempre o resultado da história de uma sociedade e, na sua realidade empírica, são um composto muito heterogêneo que combina orientações e níveis diversos de ação. Desde modo, acabou-se por eliminar da cena a questão verdadeiramente importante, isto é, aquela que se refere à mudança do contexto estrutural e categorial das sociedades contemporâneas (MELUCCI, 2001, p. 9).
\end{abstract}

Desse modo, coerente às concepções de Melucci em relação a sua forma de compreender e analisar os movimentos sociais, neste texto será adotada a expressão "Movimentos Sociais" e não mais a de Novos Movimentos Sociais.

Segundo Melucci (1994), as sociedades são históricas. Isso significa dizer que a sociedade de hoje está intrinsecamente relacionada com a de ontem. Além disso, para o autor, elas são estratificadas "em termos de diferentes camadas históricas. Qualquer sociedade constitui a combinação de duas" (p.161). Nesse sentido, Melucci (1994) 
compreende ser possível que conflitos sociais do passado, ou suas formas de ação, reapareçam nos dias de hoje, mantendo ou não os mesmos significados. Cabe, portanto, ao analista dos movimentos sociais, frente as "configurações históricas e empíricas, em entendê-las e decompô-las para mostrar de que forma como um componente pós-moderno se articularia com um componente pré-moderno, mostrando como a interação entre ambos se modifica" (p.161). Pode-se dizer assim que os movimentos sociais não são fenômenos isolados; eles se entrelaçam historicamente conforme a sociedade se transforma.

A partir destas considerações, Melucci (1989) acredita ser necessária uma reavaliação das teorias que embasaram os estudos sobre os movimentos sociais realizados na década de 1970, por entender que neles não há a compreensão de que os movimentos sociais são sistemas em relação e de que as ações coletivas dos movimentos sociais penetram nas diversas formas de socialização e de organizações sociais existentes na sociedade.

Para Melucci (1989), é possível perceber, nos estudos desenvolvidos nos anos 70 na Europa, a adoção de certos dualismos. O primeiro deles diz respeito à dualidade isolamento e solidariedade. Por terem como base uma abordagem que, ligada às teorias de comportamento coletivo e teorias da sociedade de massas, "considera a ação coletiva como um resultado da crise econômica e desintegração social” (p. 50), estes estudos consideram os movimentos sociais como "uma expressão de interesses partilhados dentro de uma situação estrutural comum" (p. 50), ou seja, a condição da classe; não há, portanto, a possibilidade de explicar "como o ator coletivo é formado e mantido" (p. 51). A segunda dualidade destacada por Melucci (1989) diz respeito à estrutura e motivação, pois os estudos do passado consideravam a ação coletiva como "um produto da lógica do sistema ou como um resultado de crenças pessoais" (p. 51), havendo, portanto, ênfase no contexto sócio econômico, no papel da ideologia e dos valores. Segundo Melucci (1989), essas dualidades existem dada a visão estrutural da ação coletiva que sustenta tais estudos.

$\mathrm{O}$ autor discute ainda a existência de estudos desenvolvidos nos Estados Unidos neste mesmo período, realizados a partir de uma orientação sistêmica. Estes trabalhos voltaram-se para a compreensão dos movimentos sociais a partir do olhar para a mobilização de recursos, "traz[endo] à tona a dimensão de como os movimentos se mantêm através do tempo, como eles intercambiam recursos com outras instituições societárias" (MELUCCI, 1994, p. 159). Essa mobilização, segundo o autor, considera a 
ação coletiva como "meros dados" e "não conseguem examinar seu significado e orientação" (MELUCCI, 1989, p. 52).

Desse modo, para Melucci (1989), os estudos desenvolvidos nos anos 70, de base marxista, e as teorias sistêmicas norte-americanas mostram-se céticos em relação aos movimentos sociais, na medida em que eles subestimam a simples lógica dos atores coletivos. Este fato acaba por promover a visão equivocada de que a ação coletiva é uma coisificação, não percebendo, portanto, o que os movimentos sociais dizem de si mesmos, ou seja, o porquê e como se constitui "o sistema de relações internas e externas que constitui a ação" (p. 51).

$\mathrm{O}$ autor discute ainda a existência de outros estudos norte-americanos desenvolvidos na década de 1980 que, por voltarem sua atenção para os movimentos políticos, acabaram por focalizar apenas as formas de mobilização para a consecução do movimento, como o protesto, a manifestação, o confronto, entre outros. Centram-se, assim, nas orientações de oportunidades e coerções, "parte de um sistema de relações que inclui respostas do sistema político e a interação entre grupos de protesto e elites" (MELUCCI, 1989, p. 53), perdendo-se, desse modo, as orientações subjetivas que possibilitaram o movimento.

Melucci (1989) critica ainda, com relação a estes estudos, o conceito de estrutura de oportunidade política desenvolvida por Tarrow. Para este autor, a ação coletiva é entendida como "um sistema e não apenas como uma crença ou um conjunto de interesses objetivos" (p. 53). Nesse sentido, seus estudos abordaram a "conexão entre ciclos de protesto e ciclos de reforma" (p. 53) que, por partirem de uma leitura marxista, relacionavam os movimentos sociais ao conflito social e à busca por mudanças. Para Melucci (1989), os estudos de Tarrow, assim como os discutidos anteriormente, concentraram-se mais nos movimentos políticos do que nos movimentos da sociedade civil, desconsiderando, portanto, que os conflitos sociais têm também como base a busca por "solidariedade e identidade" (p. 53). Ou seja, os movimentos concentram-se mais "nas necessidades de auto-realização, mas não numa orientação política, porque contestam a lógica do sistema nos campos culturais e na vida cotidiana" (p. 54). Melucci (1989) discute ainda que, apesar de Tarrow considerar as diferenças existentes entre "movimentos (como formas de opinião de massas), organizações de protesto (como formas de organizações sociais) e eventos de protesto (como formas de ação)" (p. 55. 
Ênfase do autor), ele deixa em aberto o fato de cada um possuir um significado e uma orientação diferente. Para o autor, este posicionamento, evidencia

a mesma falta de distinção entre uma generalização empírica e uma definição analítica. Como se diferenciar entre um tumulto antigovernamental de bêbados, uma greve sindical e uma ampla mobilização contra a política nuclear? Todos eles podem ser empiricamente considerados como protestos, mas cada um deles tem um significado e uma orientação significativamente diferente (MELUCCI, 1989, p.55).

Torna-se importante destacar que, apesar das críticas realizadas, Melucci (1989) não ignora a relação existente entre movimentos sociais e sistemas políticos; estas se voltam para a forma como as análises dos movimentos sociais estavam sendo realizadas até aquele momento - uma observação direta (logo empírica) dos movimentos visando relacioná-los, de forma exagerada, com a ação política. $\mathrm{O}$ autor chama a atenção ainda para os problemas destes posicionamentos, ao considerar que, exatamente naquele momento, os movimentos estavam se deslocando para um terreno não político.

Embora a relação entre sistemas políticos e movimentos sociais seja uma perspectiva analítica que é difícil de evitar em sociedades complexas, é uma perspectiva limitada. Os conflitos sociais contemporâneos não são apenas políticos, pois eles afetam o sistema como um todo. A ação coletiva não é realizada apenas a fim de trocar bens num mercado político e nem todo objetivo pode ser calculado. Os movimentos contemporâneos também têm uma orientação antagônica, que surge de e altera a lógica das sociedades contemporâneas (MELUCCI, 1989, p.54).

Os movimentos sociais, de acordo com Melucci (1989), são como redes de movimentos, ou seja, "uma rede de grupos partilhando uma cultura de movimento e uma identidade coletiva" (p. 60), conforme descrito por Reynaud, em 1982. Esta conceitualização, para Melucci (1989), aproxima-se do conceito de indústria de movimento social defendido por Zald, entendido como o "conjunto de organizações orientado para a mesma espécie de mudança social” (p. 60), bem como do conceito de setor de movimento social, de Garner e Zald de 1981, "que inclui todo tipo de ações orientadas para os objetivos dos movimentos" (p.60). No entanto, Melucci (1989) destaca que, para ele, a compreensão dos movimentos sociais deve incluir tanto organizações formais como redes de organização informais, "que conectam núcleos de indivíduos e 
grupos a uma área de participantes mais ampla" (p.60). Esta forma de se entender os movimentos sociais permite compreender que, atualmente, as formas de organização dos movimentos diferem, de forma significativa, daquelas das organizações políticas tradicionais.

Nesse sentido, pode-se afirmar que os movimentos sociais consistem em sistemas de relação imersos na vida cotidiana, que se constituem a partir de

uma rede de pequenos grupos imersos na vida cotidiana que requerem um envolvimento pessoal na experimentação e na prática da inovação cultural. Eles surgem apenas para fins específicos, como por exemplo, as grandes mobilizações pela paz, pelo aborto, contra a política nuclear etc. A rede submersa, embora composta de pequenos grupos separados, é um sistema de troca (pessoas e informações circulando ao longe da rede, algumas agencias, como rádios livres locais, livrarias, revistas que fornecem uma determinada unidade) (MELUCCI, 1989, p. 61).

Estas redes, no entanto, possuem características específicas, como por exemplo, a permissão para que ocorram associações múltiplas, militância parcial e curta e o envolvimento pessoal e a solidariedade afetiva, condição importante na medida em que há a participação de diferentes grupos sociais.

Além disso, Melucci $(1989,2001)$ defende que a existência dos movimentos sociais depende de duas condições permanentes, que se alternam no decorrer do tempo: a latência e a visibilidade. Por meio da latência torna-se possível que os atores sociais organizem a mobilização, criem uma rede de solidariedade, bem como uma estrutura cultural. Ou seja, ela "permite que as pessoas experimentem diretamente novos modelos culturais - uma mudança no sistema de significados - que, com muita frequência, é oposta às pressões sociais dominantes" (MELUCCI, 1989, p. 61). Ela permite ainda a visibilidade, alimentando-a para que ocorra a renovação da solidariedade, como a ação de novos atores coletivos e de novos militantes, tornando visíveis problemas e lugares que transcendem o grupo e sua especificidade. “A visibilidade reforça as redes submersas. Fornece energia para renovar a solidariedade, facilita a criação de novos grupos e o recrutamento de novos militantes atraídos pela mobilização pública que então flui na rede submersa" (MELUCCI, 1989, p. 62).

Importante ressaltar que no dinâmico processo de passagem da latência para a visibilidade e vice-versa, 
alguns atores desaparecem, outros se formam, consolidam-se processos de institucionalização e de modernização, mas nascem também novos problemas e se revelam novos espaços de conflitos. A forma cultural dos movimentos abre o problema crucial da relação com os sistemas políticos, e coloca, em primeiro plano, o questionamento sobre formas de representação e de organização adequadas aos novos atores (MELUCCI, 2001, p. 123).

Para Melucci (2001), cada movimento social pode ser considerado um sistema de ação; isto significa dizer que a ação coletiva se organiza a partir de objetivos, recursos e limites que se concentram na orientação construída "por meio de relações sociais no interior de um campo de oportunidades e de vínculos" (p. 46). Os atores coletivos são quem constroem, dão ordem e definem a ação na relação com o ambiente, com outros atores, com os recursos que possuem disponíveis, com as possibilidades de agir e com os obstáculos que enfrentam, mantendo, desse modo, relações com outros no interior do mesmo grupo como forma de "dar sentido ao seu agir comum e aos objetivos que perseguem" (p. 46).

Nesse sentido, para o autor, a definição da ação coletiva, pelos atores coletivos, não pode ser considerada linear, já que ela será negociada constantemente entre os indivíduos a fim de se chegar a uma decisão unânime sobre a forma de agir. Por este motivo, a ação coletiva deve ser compreendida como "um sistema de ação multipolar que combina orientações diversas, envolvendo atores múltiplos (...) [implicando] um sistema de oportunidades e de vínculos que dá forma às suas relações” (MELUCCI, 2001, p. 46).

Melucci (2001) entende que a organização da ação coletiva implica na unidade entre atores coletivos, ou seja, eles devem formar um nós, buscando o que lhes é comum; no entanto, esta unidade deve ser aceitável e durável ao sistema, que está em constante tensão. Para ele, não é, simplesmente, uma decisão imediata, tomada pelos atores coletivos, sobre o que fazer em grupo, como se fosse a expressão ou a intenção dada por alguém para realizar a ação coletiva; esta organização se dá na relação diária, quando se torna possível decidir e propor quais as ordens de orientação para que a ação seja construída coletivamente, considerando os recursos disponíveis, dentro das possibilidades e limites oferecidos.

Para esta organização, três ordens de orientação devem ser ajustadas: 
aquelas relativas aos fins da ação (isto é, do sentido que a ação tem para o ator); aquelas relativas aos meios (isto é, às possibilidades e aos limites da ação); e, por fim, aquelas relativas às relações com o ambiente (isto é, ao campo no qual a ação se realiza) (...) três eixos que devem ser considerados como um conjunto de vetores interdependentes e em tensões entre eles (MELUCCI, 2001, p.46).

Estas tensões podem ocorrer de diferentes maneiras, como exemplificou Melucci (2001, p. 47):

os objetivos não são adequados aos meios ou vice-versa; o ambiente é pobre ou rico de recursos pertinentes; os meios são mais ou menos congruentes no que se refere ao campo de ação. Também no interior dos eixos são produzidas, continuamente, tensões: na definição dos fins, entre fins de breve e longo prazos; na escolha dos meios entre a destinação dos recursos para busca da eficácia ou da consolidação da solidariedade; nas relações com o ambiente, entre equilíbrio interno e relações de troca com o exterior.

No decorrer do processo, cabe, então, aos atores, a negociação e a renegociação destes aspectos pertinentes à ação. A fim de se obter um modo mais estável e previsível às definições e decisões que serão tomadas, reflete-se, muitas vezes, sobre as próprias formas organizativas e sobre a liderança de tal movimento. De acordo com Melucci (2001), estes aspectos da ação coletiva, de suma importância para os estudos sobre movimentos sociais, geralmente, passam despercebidos, na medida em que a tendência é centrar-se mais nos aspectos visíveis da ação, que está na centralidade da conjuntura social, ao invés de no interior do sistema de relações entre atores coletivos.

A ação coletiva pode ainda assumir diversas formas e orientações, razão pela qual Melucci (2001) a considera como plural. Adverte ainda que esta ação não pode ser assumida na sua globalidade, "porque não expressa nunca uma linguagem unívoca. Uma aproximação analítica dos movimentos implica na decomposição do objeto segundo o sistema de relações sociais investido pela ação e segundo as orientações que tal ação assume" (p. 33). Para se chegar ao significado do fenômeno, portanto, deve-se sempre considerar o sistema de relações a que a ação faz referência, assim como a natureza do conflito que se estabelece. Neste sentido, "somente sob a condição de distinguir planos e significados diversos da ação coletiva será possível compreender os conteúdos de um movimento concreto, portador de instâncias múltiplas e frequentemente contraditórias" (p. 33). 
Compreende-se assim que a ação coletiva pode assumir diferentes significados e materializar-se de distintas formas, assim como também é diversa a maneira como ela se relaciona com os sistemas sociais no decorrer do tempo, no mesmo ou em diferentes espaços sociais. Assim, se por um lado a ação coletiva está submersa na vida cotidiana (latência), por outro, quando ocorre algo que afeta o interior das relações entre atores coletivos, estes se unem para enfrenta-lo (visibilidade). Esse modo de agir coletivamente pode apenas ser compreendido a partir dos conceitos de conflito, solidariedade e ruptura dos limites do sistema.

O conflito ao qual Melucci (2001) faz referência, pode decorrer de uma relação de oposição entre dois (ou mais) atores que se confrontam para o controle de recursos aos quais são atribuídos valor e/ou realizar-se por meio do consenso entre os atores a respeito das regras e dos procedimentos necessários para o controle dos recursos por eles valorizados. Infere-se, portanto, que o conflito é decorrente de situações sociais que, por afetar os atores coletivos - suas motivações e padrões culturais, suas vidas cotidianas, suas identidades -, leva-os a criar formas organizacionais para "revelar os projetos, anunciar para a sociedade que existe um problema fundamental numa dada área" (p. 59).

Para que o conflito exista, no entanto, os atores sociais envolvidos devem ser definidos a partir de um sistema de referência que lhes seja comum e demonstrar, seja de forma implícita ou explícita, o que os levou à ação. Melucci (2001) destaca ainda que se há movimento é porque existem, na sociedade, conflitos a serem resolvidos, ou seja, de forma contrária ao que se acredita, os movimentos não podem ser entendidos como uma resposta à crise; por meio deles é possível reconhecer a "existência de questões coletivas que atingem a legitimidade do poder e o uso dos recursos sociais” (p. 34-35). É, portanto, uma forma de reação frente às questões já existentes na sociedade.

Diante de um conflito, os atores se definem para mobilizarem um movimento, a partir de uma solidariedade específica, conceito compreendido por Melucci (2001) como sendo "a capacidade dos atores de se reconhecerem e serem reconhecidos como parte da mesma unidade social” (p. 35). Entende-se desse modo que, a partir do reconhecimento do conflito pelos atores coletivos, há a busca por uma forma de se unir para agir coletivamente a fim de lutar contra "adversários" nas relações sistêmicas, rompendo assim com os limites do sistema. 
A ruptura com o sistema pode se dar de duas maneiras distintas. A primeira delas ocorre a partir da busca por estratégias para se resolver um conflito: o movimento tenta negociar alternativas viáveis para que as mudanças sociais desejadas ocorram e, portanto, problemas piores sejam evitados. Rompe-se, portanto, parcialmente com as determinações do sistema que tentam estabilizar o conflito, negando-o. Melucci (1989) discute esta forma de ruptura a partir do conceito de limites de compatibilidade do sistema que, segundo o autor, "indicam o espectro de variações tolerado dentro de sua estrutura existente" (p.56). No segundo caso, o movimento visa a ruptura total do sistema imposto e, portanto, a mudança social, ou seja, há um rompimento dos limites empurrando o "sistema para além do espectro aceitável de variações" (p. 56).

Esta última forma de romper com os limites de compatibilidade dos sistemas, segundo Melucci (2001), pode ser entendida como um desvio ou condutas desviantes, por meio das quais

\begin{abstract}
o ator é definido pela sua marginalidade no que refere a um sistema de normas e reage ao controle que essas exercitam sem, todavia, colocar em discussão a sua legitimidade, sem individuar um adversário social e um conjunto de recursos ou valores pelo qual se luta. Fruto da desagregação da ordem ou da assimilação inadequada das normas por parte dos indivíduos, o desvio se resolve na busca de recompensas particulares e fora das condutas sociais. (MELUCCI, 2001, p. 37)
\end{abstract}

Nesse sentido, para o autor, as condutas desviantes não podem ser consideradas uma patologia social, mas sim compreendidas a partir de seus condicionantes com o sistema normativo e dominante.

É, portanto, a partir da relação social na vida cotidiana dos membros da ação coletiva e da relação entre conflito, solidariedade e ruptura no agir coletivo, que Melucci $(1989,2001)$ buscou compreender como e porquê emergem as ações constituídas pelos atores coletivos, compreendidos como seres históricos que usam suas vozes e seus atos para agir, de forma coletiva, no decorrer da história. Em outras palavras, os movimentos sociais sempre se modificam pela lógica dos atores coletivos em contextos sóciohistóricos determinados. Nesse sentido, as ações coletivas desenvolvem-se na concretude da prática social existente em diferentes agrupamentos sociais, sempre na "combinação de processos diversos: uma escola, uma fábrica, uma cidade, são resultantes de estruturas produtivas, de sistemas de estratificação, de processos decisórios, de sistemas simbólicos, 
de formas de poder, assim por diante" (MELUCCI, 2001, p. 38). Compreende-se, portanto, que as ações coletivas são formas especificas de relações sociais.

Por meio destas relações é possível perceber o comportamento dos atores sociais. Melucci (2001) cita três exemplos: os movimentos reivindicativos, políticos e antagonistas. Para ele, os movimentos reivindicativos são modos nos quais "o ator coletivo reivindica uma diversa distribuição dos recursos no interior da organização, luta por um funcionamento mais eficiente do aparato, mas se confronta também com o poder que impõe as regras e as formas de divisão do trabalho" (p. 41). Os movimentos políticos caracterizam-se por uma oposição à supremacia de outros grupos; constituem-se, portanto, por uma luta que visa garantir o acesso e abrir possibilidades de participação e de voz nas decisões que envolvem questões sociais. Os movimentos antagonistas, por sua vez, ocorrem quando a produção de recursos de uma sociedade é atingida. É uma "luta não só contra o modo pelo qual os recursos são produzidos, mas coloca em questões os objetivos da produção social e a direção do desenvolvimento" e materializam-se por meio "dos sistemas organizativos e através das formas de representação e de decisões políticas" (MELUCCI, 2001, p. 42).

No contexto deste último movimento, os atores coletivos procuram manter sua autonomia diante dos sistemas políticos e produtivos. No entanto, para o autor, não é fácil evidenciar quais formas da ação se originam da orientação antagonista, mas eles podem ser percebidos, em especial, quando observados "na linguagem do seu sistema cultural, como uma luta entre quem produz os recursos sociais fundamentais e quem deles se apropria. A aposta em jogo nessa luta será sempre, direta ou indiretamente, o controle de tais recursos, isto é, do modo de produção da sociedade" (MELUCCI, 2001, p. 44-45). Desse modo, compreende-se que toda a produção dos movimentos é social.

Diante da produção social das ações coletivas, Melucci (2001) leva ainda em consideração que a produção social é construída pela ação humana, entendida como

um comportamento finalizado capaz de reflexividade, isto é, capaz de produzir a própria orientação e de reconhece-la. E ao mesmo tempo, um comportamento social, definido pela interdependência e pelas trocas simbólicas que ligam entre eles os humanos. (MELUCCI, 2001, p. 49).

A produção social situa-se em um sistema de vinculo construído pelos atores coletivos a fim de possibilitar uma ação transformadora, composta por "um ambiente 
natural da ação (matéria-prima) e sua base instrumental (meios de produção) [que] indicam que o agir humano que transforma o ambiente nunca é a expressão pura de uma essência, de uma intenção, de uma vontade" (MELUCCI, 2001, p. 49-50). Neste sentido, a produção social se constrói pelo reconhecimento recíproco para a "produção de sentido e de relações, mediadas simbolicamente" (p. 50) na ação coletiva. Para Melucci (2001), essa prática se comporta como uma teoria da identidade.

\section{I.3.1 Identidade Coletiva}

Melucci (2001) considera que a identidade está relacionada a processos sociais que possibilitam que as pessoas tenham capacidade reflexiva de produzir sua ação com consciência para conseguir definir seu modo de agir coletivamente.

Para que esta identidade se forme é necessário que haja produção social e, no decorrer do tempo, que se aprenda o que significa o coletivo. A reflexão sobre a identidade coletiva é possibilitada pelo compartilhamento de aspectos da vida cotidiana, de um grupo que não é conhecido e, portanto, reconhecido em sua diferença. Nesse processo, o potencial da capacidade reflexiva constitui-se a partir da produção de sentido da motivação para a ação coletiva:

não é apenas somente a natureza externa que é transformada pela ação social, mas é a ação mesma nas suas raízes motivacionais que se transforma em produto de relações sociais. Essa "socialização" crescente torna disponível um potencial de "diferenciação", de apropriação individual do sentido da ação, nunca antes experimentado. De outro lado, isto significa também aumento do controle sobre processos de formação e de transformação da identidade, erosão das margens de independência individual do sistema, regulação "social" do comportamento até o nível de formação do seu sentido (MELUCCI, 2001, p. 91)

Deste modo, a ação coletiva não pode ser compreendida apenas como transformação social; ela se dá também no momento de reconhecimento recíproco, do conhecimento do que é a identidade coletiva; portanto, ela sempre será construída socialmente entre atores coletivos. Melucci (2001) discute ainda que a formação da identidade coletiva não é dada, premeditada ou imediata, como se fosse simplesmente um conjunto de características prontas por meio das quais os indivíduos se identificam ao se 
encontrarem nos diferentes espaços sociais; ela constitui-se em processo, já que estará em construção permanente no sistema de relações. Nesse processo de formação identitária, os atores sociais precisam participar ativamente das questões que envolvem o cotidiano do grupo para trocas, negociações e decisões que envolvem o coletivo. Esta convivência permite, portanto, que os atores se apropriem dos sentidos e internalizem os valores específicos daquela coletividade para terem capacidade de entender qual é a sua identidade e explicar os motivos de suas ações para si mesmos e para os outros. Em outras palavras, se os atores não tiverem um entendimento claro sobre a definição da sua identidade coletiva, não entenderão os motivos da sua participação nas ações coletivas.

Para a construção do processo identitário, Melucci (2004) entende que, inicialmente, o homem deve se livrar das influências dos sistemas sociais; em seguida perceber e compreender os limites das relações que ele estabelece com outros para, posteriormente, reconhecer-se e ser reconhecido pelo outro. Portanto, o processo de formação da identidade pressupõe autoidentificação. Nas palavras do autor, o "reconhecimento intersubjetivo para alicerçar nossa identidade" (p. 45). É, portanto, nas relações interpessoais, nas aprendizagens mútuas construídas nas vivências sociais, que será possível, ao ator, definir-se em relação ao grupo ao qual ele pertence.

No entanto, esta identidade não pode ser compreendida de forma fixa, pois ela se transforma continuamente no decorrer das vivências e aprendizagens cotidianas, que nos levam a questionar e a reformular nossa identidade. Nesse sentido, para Melucci (2004, p.48), a identidade "implica uma capacidade de perceber a duração, permitindo-nos estabelecer relações entre passado e futuro e ligar a ação com seus efeitos. Somente atendendo a essa condição é que podemos falar de nós mesmos no tempo" (p. 48).

Neste processo, podem haver conflitos nas relações sociais no interior do próprio grupo, assim como deste com os sistemas sociais, quando, estes últimos buscam realizar intervenções sobre a estrutura biopsíquica do coletivo, por meio da regulação do comportamento interpessoal dos grupos identitários. Essas intervenções e a regulação do comportamento foram consideradas, por Melucci (2001), como uma racionalidade "normalizadora", responsável pelo desenvolvimento do sentido do agir. Ou seja, os sistemas sociais acreditam ter o direito de interferir nas questões coletivas dos grupos, que, por sua vez, reagem, coletivamente, contra ela, reivindicando seu "direito à autônoma definição de identidade” (p. 92). Esta reivindicação, porém, não se dá de forma 
impositiva, mas por meio de um agir coletivo que indica os modos próprios de viver, as perspectivas de mundo, as formas de dizer e de pensar específicas do grupo e, portanto, distinta dos demais coletivos sociais. Esta forma de agir é a condição própria do ator social.

A condição social da identidade coletiva liga-se, ainda, intrinsecamente, com a cultura, entendida como a forma como os homens se constituem socialmente por meio da linguagem - gestos, ações e palavras - responsável pela definição das "experiências fundamentais da falta, isto é: o limite, a morte e alteridade" (MELUCCI, 2004, p. 38). É, justamente, a percepção da falta que mobiliza os atores a estreitarem suas relações interpessoais como forma de definir suas necessidades, estabelecendo "uma ponte entre a experiência subjetiva profunda, principalmente sensorial, e uma rede de relações sociais à qual pertencemos e na qual buscamos as palavras para dar nome àquilo que nos acontece" (MELUCCI, 2004, p. 39).

A representação linguística da necessidade constituída, portanto, no processo de organização social e cultural, permite que os atores reivindiquem sua inserção nos sistemas sociais e torne-a visível a outros grupos sociais. Nesse contexto podem ser compreendidos alguns movimentos sociais que determinaram inovações culturais: a ação promovida "pelos movimentos feministas, ecológicos e juvenis dos últimos vinte anos, deu origem a uma definição de necessidades como expressão de uma natureza que resiste ao social ou que contra ele se rebela" (MELUCCI, 2004, p.40). Este processo implica ainda na necessidade de os grupos assumirem um posicionamento político, única forma de ser possível o "reconhecimento do direito à diferença e à construção de uma identidade coletiva" (BRITO, 2013, p.65).

Para finalizar este capítulo, reitera-se, em consonância com Melucci (1989, 2001, 2004), que a compreensão dos movimentos sociais não é algo simples, pois para fazê-lo deve-se empreender uma reflexão crítica sobre os aspectos macro e microssociais que determinam as ações coletivas de determinados grupos sociais. 


\section{CAPÍTULO II}

\section{PROCEDIMENTOS METODOLÓGICOS}

Neste capítulo são apresentados os procedimentos metodológicos adotados para esta pesquisa, que teve como objetivo compreender o processo histórico das ações coletivas dos surdos da Associação de Surdos de São Paulo (ASSP), entre os anos de 1950 a 2011, período que compreende a fundação desta instituição e a criação das Escolas Municipais de Educação Bilíngue para Surdos (Emebs) na capital paulista. Neste contexto, o estudo buscou entender como surgiram estas ações coletivas e como elas se mantiveram no decorrer do período investigado.

Para o desenvolvimento desta pesquisa, compreendeu-se, em consonância com Minayo (2015), que a ciência não é um trabalho conclusivo e definitivo, mas sim uma busca constante por respostas, com vistas a compreender, estudar e pesquisar fenômenos que cercam a vida dos seres humanos. Segundo a autora,

\footnotetext{
Na sociedade ocidental, no entanto, a ciência é a forma hegemônica de construção da realidade, considerada por muitos críticos como um novo mito, por sua pretensão de único promotor e critério de verdade. No entanto, continuamos a fazer perguntas e a buscar soluções. Para problemas essenciais, como a pobreza, a miséria, a fome, a violência, a ciência continua sem respostas e sem propostas (p. 9-10)
}

Para Minayo (2015), o objeto das pesquisas em Ciências Sociais é histórico, possui consciência histórica, havendo identidade entre sujeito e objeto. No que diz respeito à historicidade do objeto, a autora considera que o que está dito não se constitui uma novidade, mas possui particularidades determinadas pelo contexto, em seu tempo e espaço específico, em uma relação dialética entre passado, presente e futuro. Assim, o que é dado não é um fato isolado na história e está sempre em construção.

as sociedades vivem o presente marcado por seu passado e é com tais determinações que constroem seu futuro, numa dialética constante entre o que está dado e o que será fruto de seu protagonismo. Portanto, a 
provisoriedade, o dinamismo e a especificidade são de qualquer questão social. (MINAYO, 2015, p. 12)

No que se refere à consciência histórica, entende-se que o sentido da pesquisa é dado tanto pelo investigador quanto pelos grupos sociais investigados, que investem intencionalidade às suas ações, projetando e planejando o futuro, em um nível de racionalidade que torna o humano capaz de explicá-las a partir de um determinado contexto histórico. Reconhece-se ainda, nas pesquisas em Ciências Sociais, a existência de uma identidade entre sujeito e objeto, na medida em que estas, ao lidarem com seres humanos que possuem um substrato cultural, de classe ou por faixa etária comum ao investigador, comprometem pesquisador e seu objeto. Pode-se dizer assim, que "a visão de mundo de ambos está implicada em todo o processo de conhecimento, desde a concepção do objeto aos resultados do trabalho e à sua aplicação" (MINAYO, 2015, p.1314), o que torna a pesquisa em Ciências Sociais intrínseca e extrinsecamente ideológica.

A autora destaca, no entanto, a importância do universo social do pesquisador, pois "o ser humano se distingue não só por agir, mas por pensar sobre o que faz e por interpretar suas ações dentro e a partir da realidade vivida e partilhada com seus semelhantes" (MINAYO, 2015, p. 21). Nesse sentido, todo o ciclo de pesquisa, construído a partir de um ritmo próprio e particular, deve constituir-se por um trabalho artesanal na busca por fontes que possibilitem a compreensão da realidade, mas que não prescinde da criatividade do pesquisador. É, conforme Minayo (2015), um trabalho em espiral, cuja origem está na proposição de um problema e seu fim na obtenção de uma resposta que dará origem a novas indagações.

A autora afirma ainda que a construção metodológica de um trabalho de pesquisa deve incluir concepções teóricas condizentes com o objeto, um conjunto de técnicas que permitam a aproximação e a construção da realidade, somado ao potencial criativo do investigador. A articulação da teoria, da técnica e da leitura do pesquisador que permitirá, portanto, o esclarecimento do objeto da pesquisa.

O ciclo de pesquisa, segundo a autora, tem início com a fase exploratória, na qual o pesquisador deve interrogar-se sobre o objeto, as teorias e pressupostos que sustentarão a pesquisa, bem como sobre os aspectos metodológicos que serão seguidos na construção do estudo. A esta segue a fase do trabalho de campo, na qual serão escolhidos e trilhados os procedimentos de coleta dos dados; e, para finalizar o ciclo, cabe ao pesquisador 
analisar e tratar o material empírico elou documental de forma articulada com a teoria que fundamentou a pesquisa. Este ciclo, no entanto, "não se fecha, pois toda pesquisa produz conhecimentos e gera indagações novas" (MINAYO, 2015, p.27).

Pelos aspectos descritos, compreende-se, portanto, que o objeto das Ciências Sociais é essencialmente qualitativo, na medida em que se estuda o dinamismo específico da vida individual e coletiva "com toda a riqueza de significados dela transbordante" (MINAYO, 2015, p. 14). No entanto, a autora reconhece ser impossível, ao pesquisador, a explicação da totalidade da vida social; por este motivo, cabe a ele procurar instrumentos e teorias que permitam uma aproximação da vida humana em sociedade, mesmo "que de forma incompleta, imperfeita e insatisfatória" (p.14).

Considerando o objeto de estudo do presente trabalho de pesquisa, a teoria de Alberto Melucci $(1989,1994,2001,2004)$ mostrou-se a mais adequada para que esta pesquisadora pudesse explicar e compreender as ações coletivas dos surdos da cidade de São Paulo. E consciente quanto às limitações de qualquer perspectiva teórica, a função desta situa-se no:

a) (...) esclarecer melhor o objeto de investigação;

b) (...) levantar as questões, focalizar o problema, as perguntas e a estabelecer as hipóteses com mais propriedade;

c) [permitir] maior clareza na organização dos dados; e

d) (...) [iluminar] a análise dos dados, embora não possam direcionar totalmente essa atividade que deve se beneficiar dos achados empíricos, sob pena de anulação da originalidade propiciada pela pergunta inicial (MINAYO, 2015, p.17-18).

Assim, buscou-se, por meio desta pesquisa, compreender o objeto em estudo para além das aparências e do nível discursivo constitutivos da realidade investigada, analisando as ações coletivas dos surdos de São Paulo a partir de dois níveis de relação macrossociais e microssociais - na medida em que, para Melucci (2001), estudar ações coletivas implica em considerar o contexto destes em sua realidade concreta e as relações sociais no interior de uma determinada ação coletiva. 


\section{II.1 A Coleta dos Dados}

Os procedimentos de coleta de dados visaram possibilitar uma visão ampla da totalidade dos fenômenos, por compreender "que os fatos sociais não podem ser entendidos quando considerados isoladamente, abstraídos de suas influências políticas, econômicas, culturais e etc." (GIL, 2008, p. 14). Para isso, e considerando o objeto da pesquisa, foram realizadas pesquisas bibliográficas sobre a temática central do estudo; documental sobre os registros dos acontecimentos; e entrevista com dois dos principais atores sociais das ações coletivas, objetivando, assim, ordenar, historicamente, os fatos no decorrer do período de 1950 a 2011.

A pesquisa bibliográfica abordou materiais escritos por outros pesquisadores sobre movimentos sociais e movimentos sociais surdos, envolvendo teses, dissertações artigos científicos e livros. Esta pesquisa possibilitou, à investigadora, a compreensão do tema tratado nesta pesquisa e o estabelecimento de um contínuo diálogo com os diferentes autores. No que diz respeito às três primeiras fontes de dados, para seu acesso, foram utilizadas as ferramentas de busca do Google Acadêmico, de sites de periódicos científicos e na Biblioteca Digital Brasileira de Teses do Instituto Brasileiro de Informação em Ciência e Tecnologia (IBICT). As palavras de busca utilizadas foram: "movimentos sociais na cidade de São Paulo", "lutas de surdos", "movimentos surdos", "movimentos surdos São Paulo". Foram encontrados e escolhidos cinco artigos científicos (RAMOS, 2004; MONTEIRO, 2006; SILVA et. al., 2009, 2011; CAMPELLO, REZENDE, 2014), um capítulo de E-book (BRITO; NEVES; XAVIER, 2013), uma tese de doutorado (BRITO, 2013) e uma dissertação de mestrado (RANGEL, 2004). No que diz respeito aos livros, foram lidos aqueles que diziam respeito aos movimentos sociais de forma geral.

A pesquisa documental envolveu materiais não encontrados nas fontes acadêmicas pesquisadas, que também se constituíram em fontes de pesquisa; por meio deles foi possível extrair, parcialmente, informações que a pesquisadora julgou importantes para responder aos objetivos deste estudo e, portanto, reconstruir, historicamente, os fatos relativos aos movimentos sociais surdos. Para a obtenção e escolha destes materiais, foram considerados documentos escritos em língua portuguesa e vídeo-gravados em Libras nos seguintes espaços: Google, Portal da Prefeitura de São Paulo; Portal de Memorial de Inclusão; Revista Eletrônica Ponto Urbe, Biblioteca Virtual 
do Portal da Feneis; Blog que aborda os movimentos das comunidades surdas, em especial aqueles que envolviam a Comunidade Surda de São Paulo; vídeos postados na plataforma YouTube do historiador surdo Antônio Campos de Abreu.

Como fonte documental, a pesquisadora teve ainda acesso aos cadernos de atas $n^{\circ}$ 8 e n⿳8一 da ASSP, nos quais se encontram o registro da instituição no período de 1986 a 1998 e de 1986 a 1995 respectivamente. Por meio destes documentos foi possível encontrar algumas informações relevantes à pesquisa, como por exemplo, as reformulações de estatuto, o nome das pessoas que assumiram os cargos de diretoria, a alteração de nome da instituição e as ações visando a difusão da Libras, além de dados que demonstram a preocupação da ASSP com a vida social e educacional dos surdos.

Como último procedimento de coleta de dados foram realizadas duas entrevistas narrativas. De acordo com Muylaert et al. (2014), a fim de se romper com a tradição de entrevistas baseadas em perguntas e respostas, foi construída a entrevista narrativa. Por meio dela é possível um olhar aprofundado sobre aspectos específicos de um dado momento histórico a partir da história de vida, experiência e vivência narrada pelos entrevistados, considerando-se determinados contextos sociais. Para Peregrino (2015), uma particularidade desta entrevista é o fato dela possibilitar, por não seguir uma estrutura fixa e fechada, um diálogo entre entrevistador e entrevistado, constituindo-se em um processo de "produção de linguagem, já que é, aqui, concebida como dialógica" (p. 5). Muylaert et al. (2014) discutem ainda que por intermédio das entrevistas narrativas é possível perceber e valorizar a linguagem utilizada pelo entrevistado em sua historicidade, fato que permite a compreensão da realidade por ele vivida; relatos de um passado que tem implicações diretas no presente e que se projeta para o futuro também por meio da pesquisa, na medida em que, muito do que foi contado, não está ainda registrado em documentos.

Peregrino (2015) concebe também esta entrevista como um espaço de alteridade entre entrevistador e entrevistado, no qual o sentido dado por um determinado aspecto narrado serve de completude provisória para o outro e vice-versa. Mais do que falar sobre um tema, esta narrativa constitui-se em discurso de dois sujeitos (entrevistador e entrevistado), que (re)constróem a história, os sentidos do texto, significando e ressignificando constantemente o tema. Neste contexto, cabe ao pesquisador eximir-se de todo e qualquer julgamento sobre o que está sendo dito; cabe a ele ouvir e compreender 
o que o outro diz, ao mesmo tempo em que compreende a si mesmo por partilhar um mesmo horizonte social e cultural com o entrevistado.

\section{II.1.1 Os sujeitos que participaram da pesquisa}

As entrevistas narrativas foram realizadas em dois momentos distintos. No primeiro, contou com a participação do Sr. Mario Júlio de Mattos Pimentel que, no dia da entrevista, estava acompanhado de sua esposa Sra. Marta de Mattos Pimentel. O Sr. Mario participou ativamente da fundação da ASSP e das lutas dos surdos na cidade de São Paulo em diferentes momentos históricos; no segundo, a entrevista foi realizada com o Sr. Paulo Roberto Amaral Vieira, ex-presidente da ASSP.

Mario Pimentel, conforme consta na biografia publicada por Abreu (2016a, 2016b), estudou, na década de 1930, no Instituto Santa Terezinha, em São Paulo. Neste período, toda a educação dos surdos voltava-se para a prática de oralização dos alunos, impedindo que, no interior da escola, a língua brasileira de sinais (Libras) fosse usada, sob pena de apanhar nas mãos. No entanto, esta prática não impedia que os surdos, mesmo às escondidas, se comunicassem por intermédio da Libras. Fora dos muros da escola, nos lugares onde se encontravam para bater papo, a comunicação entre eles era livre: usavam Libras, gestos, a escrita e também a linguagem oral da língua portuguesa.

Foi interessante observar, no vídeo em que Mario Pimentel contou sua história, que ao enunciar sobre a liberdade na forma de se comunicar com seus amigos, sua fisionomia se alterou; era visível a expressão de alivio complementada por um sorriso. Esta sensação de liberdade pode ser compreendida a partir da discussão realizada por Bauman (2001). Sentir-se livre, significa

libertar-se de algum tipo de grilhão que obstruiu ou impede os movimentos; começar a sentir-se livre para se mover ou agir. "Sentirse livre" significa não experimentar dificuldade, obstáculo, resistência ou qualquer outro impedimento aos movimentos pretendidos ou concebíveis (p. 23).

Entende-se, neste caso, o poder se comunicar sem a imposição de uma língua.

Ao término do ensino primário, Mario Pimentel foi convidado por um padre para conhecer e continuar seus estudos, no ginasial, em uma escola regular, onde permaneceu 
até os 17 anos de idade. Neste espaço, convivia com alunos ouvintes da mesma forma como nas práticas esportivas que desenvolvia no clube Floresta ${ }^{1}$, no qual ajudava os amigos no conselho e na organização de jogos. No entanto, o contato com seus amigos surdos permanecia e, com frequência, eles se encontravam no centro da cidade para conversar. Foi nesses encontros que Mario Pimentel percebeu que seus amigos surdos não tinham oportunidade de praticar esportes, mote que o levou, posteriormente, a trabalhar com outros amigos na fundação da Associação de Surdos de São Paulo (ASSP).

Após a conclusão do ginasial, Mario Pimentel prestou concurso e foi trabalhar como técnico de desenho na área de Arquitetura; casou-se com a Sra. Marta Pimentel, com quem teve dois filhos.

Além da importância de Mario Pimentel para a fundação e continuidade da ASSP, ele foi também o primeiro surdo a tirar carta de habilitação, não sem antes enfrentar muitas dificuldades. Embora tenha passado no exame, conseguiu o documento apenas dezessete anos mais tarde, dada a burocracia dos órgãos governamentais em Brasília na época da ditadura militar. Assim que o Conselho Nacional de Trânsito anunciou, por meio de uma resolução, que os surdos também teriam direito à carteira de habilitação, Mario Pimentel virou notícia em vários jornais: "Surdo-mudo: motorista como qualquer outro", publicado no Diário de São Paulo, em 23 de junho de 1971; “Surdo poderá se habilitar a dirigir", no Jornal do Brasil, em 18 de dezembro de 1974; "Surdos já podem dirigir carta de motorista amador para surdos", no Jornal Popular, em 10 de dezembro de 1974 (ABREU, 2016f). Observou-se que foi com muito orgulho que Mario contou sua história! Paulo Vieira estudou na década de 1980 e 1990 no Instituto Educacional São Paulo, atual Escola de Educação Básica para Surdos da Divisão de Educação e

\footnotetext{
${ }^{1}$ Mario Pimentel faz menção ao clube que frequentava na Chácara da Floresta. Este espaço foi a primeira sede do atual Clube Espéria, que mudou de instalações em 1903, quando a chácara foi comprada para sediar o Clube de Regatas São Paulo, em uma época na qual apenas se praticava esportes aquáticos no local. Em 1906, foi construído o Estádio de Futebol da Chácara e, em 1913, com o fim do Clube de Regatas São Paulo, este foi comprado pela Associação Atlética das Palmeiras. Em 1930, esta associação foi adquirida pelo recém-formado São Paulo da Floresta, sendo sua sede a partir de 1930. Em maio de 1935, o São Paulo da Floresta (desde dezembro de 1935, São Paulo Futebol Clube) foi comprado pelo Clube de Regatas Tietê, que se tornou dono do Estádio da Floresta. Este estádio existe até os dias de hoje, cercado pela Marginal Tietê, Ponte das Bandeiras e Avenida Tiradentes. Fontes: http://www.campeoesdofutebol.com.br/sao paulo floresta.html, https://porcopedia.com/index.php?title $=\mathrm{Ch} \% \mathrm{C} 3 \% \mathrm{~A} 1$ cara da Floresta, http://terceirotempo.bol.uol.com.br/que-fim-levou/chacara-da-floresta-1428.
} 
Reabilitação dos Distúrbios da Comunicação - Derdic. Por não haver jogos de futebol no espaço escolar, desde 1988 Paulo Vieira frequentava a ASSP. Nesse espaço, pode conviver e aprender com surdos mais experientes e participar na organização de ações coletivas voltadas ao esporte e a outros temas relacionados aos surdos.

Em 2007 tornou-se presidente da ASSP e apesar do foco nas práticas esportivas que constituiu esta Associação, Paulo Vieira decidiu abrir a instituição para apoiar outras questões relacionadas aos surdos, como por exemplo, a educação, a saúde, abertura de espaços de trabalho, acessibilidade, espaços políticos, entre outros. Apesar disso, o esporte continuou a ser enfatizado na instituição, por se entender esta prática como sendo de muita importância para todos os surdos, mas em especial para os jovens, prevenindo, por seu intermédio, que eles venham a fazer uso de drogas.

No período em que esteve na presidência da ASSP, Paulo Vieira, juntamente com a equipe que trabalhava com ele, passou a organizar pautas de reivindicação a fim de mudar as condições sociais dos surdos; destaca-se a criação do primeiro festival de esporte e cultura para as crianças surdas matriculadas nas escolas municipais. Outra ação realizada com apoio da ASSP, foi a criação da Central de Intérpretes de Libras (CIL), que contava, na época em que foi realizada esta entrevista, com 22 profissionais contratados. Por intermédio desta central, os surdos residentes em São Paulo podem ter intérpretes de Libras para todos os atendimentos que necessitarem, tanto nos setores públicos quanto privados.

Ao sair da presidência da ASSP, Paulo Vieira se candidatou a vereador e a deputado estadual com o objetivo de apoiar as comunidades surdas de São Paulo, mas, infelizmente, não foi eleito. Atualmente, trabalha como assessor da deputada federal Mara Gabrilli.

\section{II.1.2 Aspectos éticos}

Para a obtenção do consentimento para que os surdos viessem a ser identificados nesta dissertação, a pesquisadora fez um breve de vídeo, cerca de um minuto, no qual explicitou o objetivo deste trabalho de pesquisa e solicitou a autorização para que seus verdadeiros nomes aparecessem neste texto. Os três surdos concordaram e, para registro, gravaram um vídeo com esta autorização. 


\section{II.1.3 Realização das entrevistas}

Para fazer contato com Mario Pimentel, a pesquisadora contou com a ajuda de Paulo Vieira. Após explicar o objetivo da pesquisa, foi solicitado a ele que explicasse a Mario Pimentel sobre a mesma, na medida em que o contato com ele não era fácil, por ele desconhecer a pesquisadora e por ter tido experiências negativas com pesquisas realizadas anteriormente. Alguns dias depois, Paulo Vieira avisou que Mario Pimentel havia aceitado participar desta pesquisa, marcando o dia e o local para o encontro.

A entrevista foi realizada no dia 22 de abril de 2016, em um salão da Igreja São Francisco de Assis, localizada na Vila Clementino, na cidade de São Paulo. Estavam presentes, neste dia, a pesquisadora, um amigo que se responsabilizou pela filmagem da entrevista, Mario Pimentel, sua esposa - Marta Pimentel, e Paulo Vieira. Após a instalação da filmadora em uma mesa, a pesquisadora arrumou três cadeiras e as dispôs em frente à mesa para que Mario, Marta e ela própria pudessem se sentar. A entrevista foi iniciada.

A pesquisadora fez algumas perguntas abertas durante a entrevista e permitiu que Mario Pimentel tivesse liberdade em narrar os fatos da forma como se sentisse melhor, interferindo, desse modo, muito pouco na narrativa em desenvolvimento. Ele contou sobre vários momentos que avaliou serem importantes no decorrer de sua convivência com surdos, sobre seu período escolar e sobre seu trabalho como presidente da ASSP. Marta Pimentel complementava algumas informações, assim como Paulo Vieira. No entanto, os comentários de Paulo não foram gravados na medida em que ele se encontrava fora do foco da filmadora. Toda a entrevista ocorreu em Libras e durou cerca de 1 hora e 10 minutos.

A entrevista com Paulo Vieira ocorreu no dia 20 de maio de 2016 e foi realizada no escritório onde ele trabalha, localizado no centro da cidade de São Paulo. Da mesma forma como realizado com Mario, esta entrevista também foi filmada e durou aproximadamente 40 minutos; nela Paulo Vieira pode complementar informações não encontradas nos documentos e/ou narradas por Mario, especialmente aquelas relativas à década de 2000. Nesta entrevista estiveram presentes apenas Paulo Vieira e a pesquisadora. 


\section{II.2 Análise dos Dados}

Gomes (2015) entende que os procedimentos de análise dos dados envolvem dois aspectos: a descrição e a interpretação. A descrição é uma forma de apresentar as opiniões dos informantes, "como se os dados falassem por si próprios" (p. 80), havendo ainda a possibilidade de estes serem decompostos e dialogarem com outros. A interpretação deve acontecer após a descrição e visa construir "sentidos das falas e das ações para chegar a uma compreensão ou explicação que vão além do descrito" (p. 80). Ela deve ser norteada pela leitura compreensiva do material selecionado, ser sustentada por uma teoria, considerar a perspectiva dos atores sociais envolvidos e as informações coletadas sobre as ações coletivas.

Como fenômenos coletivos interconectados ao passado, ao presente e com projeção ao futuro, a compreensão das ações coletivas e os movimentos sociais não pode ser realizada de forma empírica, ou seja, visando captar a emergência dos fenômenos sociais em uma determinada realidade social, de modo a focalizar o objeto de forma unificada, como se ele tivesse significado em si próprio. Analisar os movimentos sociais pressupõe revelar o que não é visível de forma imediata, possível apenas por meio de um processo analítico crítico "capaz de apontar desdobramentos que estão além de uma definição dada da realidade" (MELUCCI, 1994, p. 154). Para o autor, os movimentos sociais possuem

significados, formas de ação, modos de organização muito diferenciados e que, frequentemente, investe uma parte importante das suas energias para manter unidas as diferenças. Assim, tende-se muitas vezes a representar os movimentos como personagens, com uma estrutura definida e homogênea, enquanto, na grande parte dos casos, trata-se de fenômenos heterogêneos e fragmentados, que devem destinar muitos dos seus recursos para gerir a complexidade e a diferenciação que os constitui (MELUCCI, 2001, p. 29).

Em assim sendo, um olhar analítico aos movimentos sociais deve pressupor a compreensão da ação coletiva levando em consideração os recursos internos e externos e a forma como eles são mobilizados pelos atores sociais, como as estruturas de organização são por eles constituídas e mantidas, e como são garantidas as funções das lideranças. Nesse sentido, torna-se necessário um olhar para os movimentos em sua relação com outros sistemas, uma visão "plural" dos significados que perpassam as 
relações dentro e fora dos movimentos em tela, à medida que estes se constituem um “sistema de ação que liga orientações e significados plurais" (MELUCCI, 1989, p. 56).

Torna-se ainda necessário refletir sobre os sentidos que os atores sociais produzem na construção da ação coletiva. Para isso, é preciso examinar, criticamente, a lógica dos atores mais do que aquela que determina as estruturas sociais, ao se considerar que a ação coletiva é construída por meio de atores coletivos no interior das estruturas sociais a fim de dar forma ao movimento. É a partir dos atores coletivos que se torna possível compreender a realidade social não cristalizada, cuja "ação é a portadora imediata da tessitura relacional da sociedade e do seu sentido" (MELUCCI, 1994, p. 155). Desse modo, não se é possível analisar os movimentos sociais sem considerar os atores e suas ações, pois são eles que dão sentido ao agir coletivo na relação com outros atores.

O que eu tento mostrar é que existem formas de construir uma realidade coletiva que são aparentemente estáveis, às quais as pessoas podem se referir, mas que, por trás desta aparente estabilidade, existe um esforço contínuo de interação e de negociação que é visto enquanto um sistema. Se você toma a definição que atores coletivos e organizados dão dos movimentos de que eles participam, então, você tem uma definição sistêmica da ação. Todavia, o que ocorre é uma produção contínua de relações sociais. (MELUCCI, 1994, p. 158-159)

Nesta análise, o êxito ou o fracasso dos movimentos sociais, do ponto de vista político, acabam não tendo importância, já que os temas que perpassam e motivam os movimentos sociais nunca cessam; o que há é a modificação das formas como os atores sociais se organizam para a ação coletiva, a relação que eles estabelecem com os sistemas sociais. Desse modo, caso o objetivo pretendido não seja alcançado, há a possiblidade de outros caminhos serem seguidos, seja por uma segmentação profissional, pela burocratização da ação ou pelo rompimento da ação.

Compreende-se assim como e o porquê, em pesquisas que tem Melucci (1989, 1994, 2001, 2004) como principal referência teórico-metodológica, é tão importante não perder de vista tanto os aspectos macro como microssociais.

No caso deste estudo, que visa compreender os movimentos sociais e as ações coletivas dos surdos, a pesquisadora separou os dados vindos das diversas informações obtidas nas pesquisas bibliográfica e documental e nas entrevistas narrativas a fim de contextualizar as ações coletivas em seus respectivos tempos e espaços. Ou seja, a partir da exploração do material, os dados foram organizados historicamente a fim de ser 
possível construir sentidos às ações coletivas considerando o universo sociocultural dos atores, em diálogo com as informações presentes em outros estudos. A fim de se obter a síntese interpretativa, os diferentes materiais coletados foram articulados a partir da perspectiva teórica adotada nesta pesquisa e dos objetivos deste estudo. Compreende-se, no entanto, que este processo foi bastante subjetivo, porque a leitura do material e sua organização dependiam também do contexto sócio, cultural e ideológico da pesquisadora.

No que diz respeito às entrevistas, uma dificuldade a mais precisou ser enfrentada. Embora enunciadas em Libras, Mario Pimentel fazia uso de uma linguagem de uma época e carregada de uma história que não eram partilhadas pela pesquisadora. Assim, após assistir esta entrevista, a pesquisadora teve que contar com a ajuda e com a explicação de uma amiga, a Profa. Elomena Almeida, que, além de ter trabalhado na ASSP na década de 1990, compreendia perfeitamente a forma de enunciar de Mario Pimentel. Neste contexto, para as análises, trechos relevantes da entrevista, a fim de responder os objetivos desta pesquisa, foram transcritos pela pesquisadora para a construção deste texto. 


\section{CAPÍTULO III}

\section{OS MOVIMENTOS SOCIAIS SURDOS DA CIDADE DE SÃO PAULO}

\section{III.1 A fundação da Associação de Surdos-Mudos de Surdos de São Paulo (ASMSP)}

A sociedade brasileira, na década de 1950, passava por grandes transformações em termos de estruturas sociais, econômicas, políticas e educacionais, mas também vivia certas contradições. No início de tal década, segundo Bomeny (2004), Getúlio Vargas retornou ao poder para o exercício de seu segundo mandato como presidente da república, eleito pelo povo brasileiro para governar durante o período de 1951 a 1954. Seu governo nacional-desenvolvimentista visava à expansão do desenvolvimento econômico do Brasil, marcado pelo crescimento industrial e entrada de capital estrangeiro.

Nesse contexto, a educação era tida como um fator significativo para que as metas de governo fossem alcançadas. O investimento voltou-se, na área educacional, para a abertura de cursos profissionalizantes e para a expansão do ensino supletivo com vistas à formação de mão de obra qualificada para o trabalho (REIS; PADILHA, 2010). Mas, apesar da expansão dos sistemas escolares, devido ao incentivo do Estado para que as pessoas das camadas populares ingressassem no ensino primário, Reis e Padilha (2010) e Bomeny (2004) concordaram que a preocupação maior do governo Getúlio Vargas era a inserção de novos trabalhadores no mercado de trabalho a fim de fortalecer o desenvolvimento industrial e econômico do país. A qualidade da educação oferecida a esses grupos sociais ficava em segundo plano; apenas as classes média e alta tinham maiores oportunidades educacionais e ingressavam na educação superior.

No que diz respeito aos surdos, não havia, neste período, uma preocupação específica com sua educação, embora já existissem várias instituições educacionais voltadas a este grupo social pelo país, como por exemplo, o Imperial Instituto dos Surdos Mudos, criado em 1857 e, desde 1957, denominado Instituto Nacional de Educação de Surdos (Ines) no Rio de Janeiro, e os três institutos educacionais para surdos existentes 
em São Paulo, conforme descreveram Felix (2009), Mazzotta (2011) e Assênsio (2015). O primeiro, denominado Instituto Santa Teresinha, privado e de caráter religioso, foi fundado em 1929 na cidade de Campinas e transferido para a cidade de São Paulo em 1933². O segundo, I Núcleo Educacional para Crianças Surdas ${ }^{3}$, público, foi criado pela Secretaria de Educação do Município de São Paulo por iniciativa do capitão do Exército Francisco Vieira Fonseca, pai de três crianças surdas, em 1952, e funcionava como um núcleo de recuperação especializado para surdos ${ }^{4}$; em 1956, este Núcleo foi transferido de Santana para o bairro da Aclimação e dois anos mais tarde, passou a ser chamado de Escola Municipal de Crianças Surdas. Atualmente esta escola se denomina Escola Municipal da Educação Bilíngue para Surdos (Emebs) Helen Keller. O terceiro, Instituto Educacional São Paulo (Iesp), foi fundado pelos pais e amigos de crianças com deficiência auditiva em 19545; em 1969, passou a ser mantido pela Fundação São Paulo e vinculado, academicamente, à Pontifícia Universidade Católica de São Paulo (PUCSP). Nos dias de hoje, é denominado Escola de Educação Básica para Surdos da Divisão de Educação e Reabilitação dos Distúrbios da Comunicação (Derdic).

Todos, sem exceção, seguiam a abordagem oralista, cujo objetivo primeiro era o treinamento auditivo e de fala dos alunos com vistas à inserção dos surdos na sociedade em detrimento dos conteúdos educacionais. Poucas informações foram encontradas sobre as instituições paulistanas, ao contrário do Ines, cuja história foi registrada em livro (ROCHA, 2008).

No ano de 1951, quando Getúlio Vargas retornou à presidência do Brasil, Ana Rímoli de Faria Dória assumiu a direção do Ines, cargo que ocupou por dez anos. Neste mesmo ano, foi criado o primeiro Curso Normal Especializado para a Educação de Surdos no Ines, que tinha, como corpo docente, profissionais médicos e docentes que já atuavam no Instituto. O curso, com três anos de duração, possuía um currículo muito próximo ao de um Curso Normal e continha um núcleo específico, composto pelas seguintes disciplinas:

\footnotetext{
${ }^{2}$ Disponível em: $<$ http://www.institutosantateresinha.org.br/quem-somos $>$. Acesso em 12 dez. 2016.

${ }^{3}$ Mazzotta (2001, p. 37-38)

${ }^{4}$ Disponível em: <http://wikimapia.org/5817270/pt/EMEE-Helen-Keller>. Acesso em 20 abr. 2017.

${ }^{5}$ Disponível em: $<$ http://www.pucsp.br/derdic/int_derdic/historia.htmll>. Acesso em 20 abr. 2017.
} 
Noções de Física, Histologia, Ensino Emendativo ${ }^{6}$, Elementos de Fonética, Anatomia Geral e Especializada, Didática Especial, Psicologia da Linguagem, Anatomia, Fisiologia, e Patologia da Audição e da Fonação, Educação Pré-escolar da Criança Deficiente da Audição e da Fonação (ROCHA, 2008, p.89).

Observa-se assim, que a maioria das disciplinas que compunha o núcleo para a educação de surdos voltava-se para o conhecimento do corpo, que deveria ser disciplinado e transformado de forma que o surdo se aproximasse, o máximo possível, do modelo ouvinte. Defendia-se, à época, que na qualidade de cidadãos, era um direito dos surdos falarem a língua que os caracterizaria como filhos do Brasil, reiterando, assim, o espírito nacionalista do Governo Getúlio Vargas.

São Paulo, neste período, estava em pleno crescimento demográfico dada a crescente migração em decorrência do processo de urbanização que a cidade vivia. No entanto, segundo Marcílio (2005), a área urbana não era suficiente para acolher a todos, o que levou a população que chegava à capital paulista a construir suas próprias casas em locais periféricos, sem apoio do poder público no que diz respeito às melhorias de infraestrutura, como água, luz, rede de esgoto, transporte público e postos de saúde. Soma-se a isso, neste crescente processo de aceleração urbana, a dificuldade também do sistema educacional paulistano em acompanhar o crescimento demográfico. Estes fatos levaram a diferentes movimentos sociais que reivindicavam melhorias urbanas e expansão das escolas públicas, de ensino fundamental e médio, nas áreas periféricas.

Sobre um desses movimentos, assim relatou um ex-secretário da educação do estado:

Havia uma demanda muito grande por ensino médio na zona leste. $\mathrm{O}$ padre Ticão era radical, não marcava audiência. Ele pegava a comunidade, botava no ônibus, criança, mulher, todos, e ia pra secretaria; entrava na secretaria cantando hinos religiosos. E assim, nós o atendíamos. Não havia ensino médio na zona leste. O padre Ticão chegou lá e disse: Professor Renato, o senhor tem de abrir escolas à noite. $\mathrm{O} 2^{\circ}$ grau à noite. E aquilo foi uma guerra com as diretoras das escolas. Mas nós fizemos. E passou a haver ensino médio à noite, por essa pressão da comunidade, via Padre Ticão (MARCÍlLIO, 2005, p. 124)

\footnotetext{
${ }^{6} \mathrm{O}$ ensino emendativo tinha como objetivo "suprir falhas decorrentes da anormalidade, buscando adaptar o educando ao nível social dos normais" (JANNUZZI, 2004, p.70).
} 
No período aqui descrito, o país era regido pela Constituição dos Estados Unidos do Brasil de 1946, na qual a educação era considerada como direito de todos, podendo ser oferecida tanto no lar quanto na escola (BRASIL, 1946, Artigo 166). Reconhecia-se ainda, como princípio, que o ensino primário era obrigatório, e o oficial, gratuito a todos; o ensino oficial posterior ao nível primário seria gratuito apenas para aqueles que provassem falta ou insuficiência de recursos (Artigo 168, Incisos I e II). No que diz respeito ainda ao ensino primário, tornava-se obrigatório, para as empresas comerciais e agrícolas que tivessem mais de cem pessoas nelas trabalhando, mantê-lo de forma gratuita para os servidores e seus filhos (Artigo 168, Inciso III). Desse modo, as reivindicações populares que vinham ocorrendo na cidade de São Paulo, tinham fundamento legal, fato que obrigava o município a pensar em ações que visassem à solução do problema.

No que diz respeito aos surdos, a própria Constituição de 1946 corroborava para a manutenção da educação oralista, à medida que, à continuidade do Inciso I, do Artigo 166, que dispõe sobre a obrigatoriedade do ensino primário, encontra-se que este "só será dado na língua nacional” e, portanto, ministrado na linguagem oral da língua portuguesa. Como exposto anteriormente, a prática de ensino oralista centrava-se no ensino da fala aos surdos como forma de "igualá-los", cultural e linguisticamente, aos ouvintes, sendo, portanto, proibido o uso da língua de sinais, vista como prejudicial à aprendizagem da fala e, como decorrência, da aprendizagem escolar dos surdos. Ou nas palavras de Brito (2013, p.25),

Nos anos 1950, [...] no contexto sócio-histórico de preponderância das ideias e práticas da abordagem educacional oralista, quando se exacerbaram determinados aspectos da coerção e da violência simbólica a que estiveram submetidos os surdos usuários da língua sinalizada durante tanto tempo no nosso país.

Apesar desta coerção, a imposição do uso da comunicação oral pelos surdos ocorria nas escolas de todo o mundo; mas eles se comunicavam, nas diferentes esferas sociais (espaços públicos, associações, ambientes familiares e entre outros) por diferentes formas de comunicação (gestos, língua de sinais ou escrita) além da oralidade, principalmente fora das instituições escolares. 
Neste contexto histórico, teve início uma das primeiras ações coletivas dos surdos paulistanos: a fundação da Associação de Surdos-Mudos do Estado de São Paulo (ASMSP), em 1954. Mas esta história começa alguns anos antes.

Nos anos finais da década de 1940 e anos iniciais da década de 1950, os jovens surdos se encontravam no centro da cidade, perto da Praça da Sé, para conversar livremente, ou seja, os diálogos ali estabelecidos davam-se por meio de gestos, língua de sinais e oralização por aqueles que dela se beneficiavam. Segundo discutiu Rangel (2004), neste período da história, era costume os surdos se encontrarem, após o período escolar, em espaços públicos.

[...] aconteceu em 1950, na cidade de São Paulo, em que alguns líderes surdos e ex-alunos de INES, além de outros surdos usuários da língua de sinais, sem diferença entre classes, costumavam se encontrar na praça da Matriz ou em alguma rua (ponto de encontro para bate-papo). Este aspecto de se encontrar na rua é um costume surgido na saída da escola INES no Rio. Após sair da escola, a ideia não era ir logo para casa, mas era continuar utilizando esta língua transmissora de conhecimentos. Desse modo, se o surdo tivesse tempo disponível, ia encontrar em algum ponto com outros surdos. (...) esses pontos de encontro na praça ou na rua serviam para troca de informações, expandir a língua de sinais e programar alguma coisa ou simplesmente o prazer de estar juntos. Estes grupos estavam sempre juntos para um animado bate-papo, desconheciam as Associações de Surdos, não faziam ideia disto. Só existiam clubes de ouvintes, associações e etc. (RANGEL, 2004, p. 50-51).

Um dos surdos que frequentava estes espaços era Mario Pimentel, que concedeu a entrevista para o desenvolvimento desta dissertação. Mario participava de várias práticas de esporte com colegas ouvintes em um clube chamado Floresta, e começou a achar que, além do bate-papo, os amigos surdos poderiam também praticar esportes junto com ele. Para Mario, era perfeitamente possível que os jovens surdos jogassem futebol com adversários ouvintes, visto que, naquela época, não havia grupos de futebol unicamente de surdos para que pudessem competir entre eles.

Com esta ideia em mente, Mario Pimentel pediu a um amigo ouvinte para ir com ele à Federação de futebol da Várzea Paulistana ${ }^{7}$ para pedir permissão para a participação

\footnotetext{
${ }^{7}$ Segundo Jesus (2002), em seu estudo sobre a popularização do futebol em São Paulo, pode-se dizer que São Paulo é o berço do futebol brasileiro. Por volta do século XIX, o futebol paulistano era praticado por grupos de elite, em clubes e empresas inglesas instaladas na cidade e em algumas escolas. Teve seu primeiro jogo, seguindo as regras inglesas, entre as equipes São Paulo Railway e The São Paulo Gaz, em 1895. Por
} 
dos surdos no campeonato; este fato causou estranheza, pois os ouvintes duvidavam da possibilidade de surdos jogarem futebol já que não ouviriam o apito do juiz. O jovem Mario Pimentel então explicou, com a ajuda de um amigo ouvinte, que o apito poderia ser substituído por uma bandeira, assim os surdos poderiam vê-la caso houvesse alguma intervenção do juiz. Esta explicação causou surpresa aos integrantes da Federação, pois, devido à falta de contato com e conhecimento sobre os surdos, eles não tinham imaginado esta possiblidade. Apesar do jogo ter sido aceito, foi pedido que antes o time dos surdos fizesse um teste, enfrentando um time de jogadores ouvintes.

Pouco antes do campeonato, os jogadores surdos se organizaram, compraram vestimentas esportivas adequadas, enquanto os membros da Federação convidavam pessoas do Cambuci, onde seria realizado o jogo, e de bairros vizinhos, para assistirem a um jogo de futebol, até então inédito, entre surdos e ouvintes. O jogo acabou empatado, mas os ouvintes foram surpreendidos com as excelentes habilidades dos jovens surdos no futebol. Com isso, os jogadores surdos foram aceitos para participarem do campeonato.

Observa-se assim, nesta organização esportiva, uma primeira ação coletiva deste grupo de surdos, pois, pela primeira vez, foi possível se formar um coletivo a partir de um objetivo em comum: participar de um campeonato de futebol, obter meios para a compra de uniformes e dar visibilidade a esta ação por meio da participação de surdos e ouvintes convidados para assistirem o jogo, espaço no qual o objetivo pode ser alcançado.

Os jogos de futebol entre surdos e ouvintes continuaram na década de 1950 e grupos de surdos mais velhos passaram a ser convidados para assistirem aos jogos. Teve início assim, uma nova relação entre os grupos de surdos de diferentes condições de vida e de gerações ${ }^{8}$; mas o esporte ainda era restrito aos mais novos.

volta dos 1902, surgem os primeiros campos de várzea espalhados pelos bairros operários, conhecido como futebol popular, havendo nítida diferença entre o futebol das elites e o futebol varzeano. Por volta dos anos de 1940 e 1950, dezenas de campos de futebol passaram a existir nos bairros de São Paulo.

${ }^{8}$ Concebe-se o conceito de geração, como um "fenômeno de simultaneidade" (MANNHEIM, 1928, apud WELLER, 2010); uma possível convivência entre indivíduos de diferentes condições de vida em um mesmo tempo, vivência essa que determina influências recíprocas entre eles. Há, portanto, o estabelecimento de uma relação (não no sentido de sucessão e de idade biológica), que é determinada tanto pelo contexto social, histórico, político e ideológico, quanto pelo contexto microssocial - de construção de compartilhamento das experiências coletivas. Nesse sentido, os indivíduos vivenciam e interagem no processo de aprendizagem por meio do compartilhamento de conhecimentos produzidos socialmente ou adquiridos em um determinado espaço. Assim eles podem desenvolver sua consciência social, cultural e política para agirem coletivamente conforme seus pensamentos e dizeres. 
Do grupo de surdos mais velhos que frequentavam os jogos, Mario Pimentel destacou quatro nomes: Mario Devisate, Policarpo do Carmo Meca, José Amarildo e Armando Melloni. Este último, neste período, teve a oportunidade de realizar uma viagem de férias à Argentina com a esposa e, naquele país, encontrou um grupo de surdos na rua; decidiu conhecê-los e logo foi convidado para conhecer a Asociación de Sordosmudos de Ayuda Mutua (ASAM) ${ }^{9}$, fundada em 1912, em Buenos Aires, uma das instituições pioneiras em defesa dos direitos das comunidades surdas. Por não ter conhecimento sobre o que significava uma Associação, Armando Melloni questionou aos integrantes e ao presidente, León Vitemberg ${ }^{10}$, a função daquele espaço, descobrindo, pouco a pouco, tratar-se de um local que permitia que os surdos se encontrassem a fim de combinarem atividades coletivas voltadas, especificamente, a eles. Armando Melloni, enquanto via o relato dos surdos argentinos, percebeu que o Brasil não possuía um espaço como aquele, lembrou do grupo de jogadores surdos e imaginou que uma Associação poderia contribuir para que os jovens tivessem oportunidade de se engajar ainda mais nos esportes, além de servir como ponto de encontro para surdos de diferentes faixas etárias. Trouxe consigo esta ideia para o Brasil.

Ao retornar a São Paulo, procurou, ansioso, os amigos Mario Devisate, José Amarildo e Policarpo para lhes contar sobre a experiência de ter conhecido a Associação. Armando retornou à Argentina, agora em companhia de Policarpo, a fim de conhecer, com maiores detalhes, quais os processos que envolviam a organização de uma associação de surdos. Foram recebidos por León que, além das explicações concernentes às dúvidas apresentadas pelos brasileiros, mostrou-lhes atas e estatutos, além de explicar como organizar assembleias com a participação de todos os surdos, votações e realizar deliberações sobre o funcionamento daquele espaço. Concedeu-lhes ainda cópia de documentos que poderiam servir como modelo para a organização do estatuto e preparação das atas da associação que estava prestes a nascer no Brasil.

De volta a São Paulo, conversaram novamente com Mario Devisate que, animado com a ideia, conversou com o seu irmão, Germano Devisate, que era deputado do Partido

\footnotetext{
${ }^{9}$ Disponível em: $<\underline{\text { http: } / / \text { www.asamutual.org.ar/historia.html }>\text {. Acesso em } 12 \mathrm{dez} .2016 .}$

${ }^{10}$ Disponível em: <http://www.asamutual.org.ar/expresidentes.html>. Acesso em 12 dez. 2016.
} 
Trabalhista Nacional (PTN) $)^{11}$, para que ele o ajudasse com a organização dos documentos; os jogadores de futebol e os grupos de adultos e idosos foram também convidados para participar das assembleias, nas quais lhes foi apresentada a ideia da fundação da Associação de Surdos-Mudos de São Paulo (ASMSP). A foto a seguir mostra a primeira assembleia de surdos localizada na avenida São Joaquim, $n^{0} 571$, no bairro de Liberdade, no centro da cidade de São Paulo.

\section{Fotografia 1: Assembleia de Fundação da Associação de Surdos-Mudos de São Paulo.}

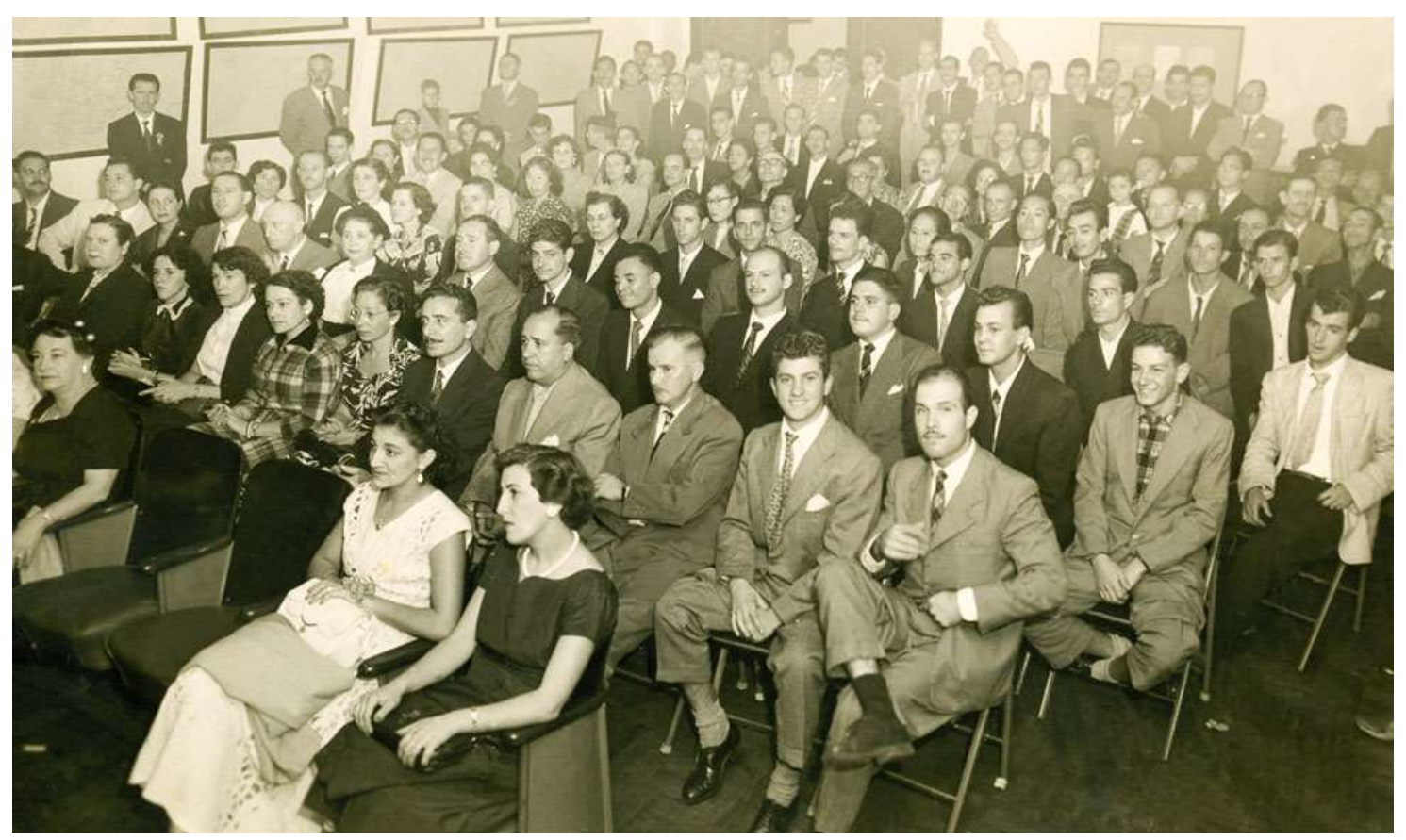

Fonte: Acervo da Associação dos Surdos Mudos de São Paulo - Memorial da inclusão ${ }^{12}$.

Nesta assembleia, foram ainda apresentados o estatuto e a logomarca da Associação e eleitos o Presidente, os $1^{\circ}$ e o $2^{\circ}$ Vice-presidentes, o Secretário Geral, os $1^{\circ}$ e $2^{\circ}$ Secretários, o Tesoureiro Geral e os $1^{\circ}$ e $2^{\circ}$ Tesoureiros, o Diretor Social, o Bibliotecário e dezessete Conselheiros. Mario Devisate foi eleito presidente, tendo como vice-presidente, Policarpo do Carmo Meca. Como Diretor de Esporte, foi eleito Mario

\footnotetext{
11 Este partido político existiu no Brasil entre 1945 e 1965. Disponível em acesso: http://www.fgv.br/cpdoc/acervo/dicionarios/verbete-tematico/partido-trabalhista-nacional-ptn). Acesso em 09. Jun. 2017.

12 Disponível em: <http://www.memorialdainclusao.sp.gov.br/br/exposicoes/tour-virtual/sala-01/ossentidos-na-comunicacao-deficiencia-auditiva/modulo-7-associacao-dos-surdos-mudos-do-estado-de-saopaulo-assp-feneis-cbds-e-copavi-sp/fundacao-da-associacao-dos-surdos-mudos-de-sao-paulo-1954/>. Acesso em 10 dez. 2016.
} 
Pimentel, um dos, então, jovens surdos responsáveis pela organização dos jogos de futebol e agregação de surdos de diferentes faixas etárias, ponto inicial para o surgimento da ideia desta Associação.

As fotos abaixo mostram o grupo de diretores e conselheiros gerais da ASMSP, em 1956, e a capa do livro de atas.

\section{Fotografia 2: Diretores e conselheiros Gerais em 1956}

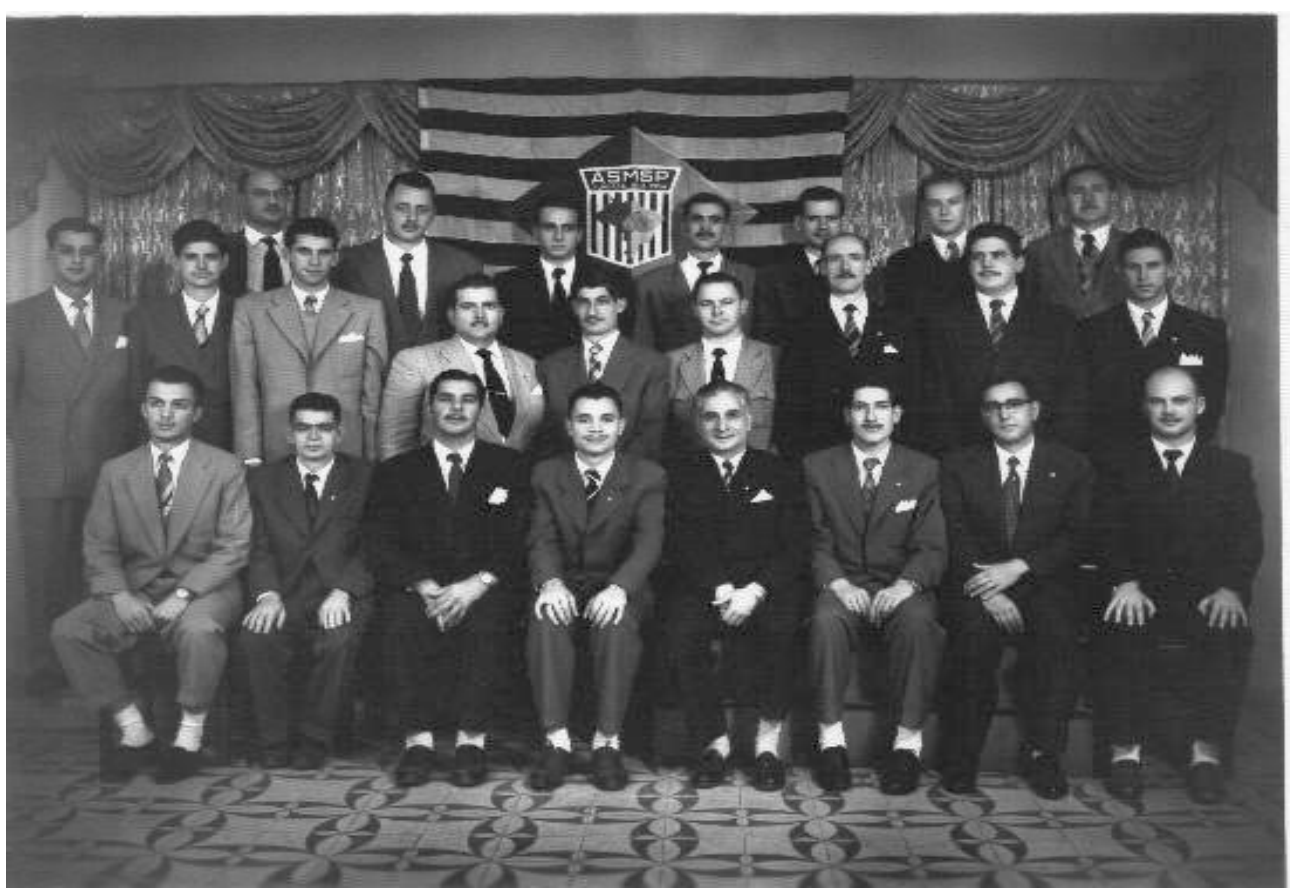

Fonte: concedida pelo ex-presidente da ASSP - Paulo Vieira

Mario Pimentel está sentado à esquerda; Mario Devisate é o quinto da esquerda para a direita. 
Figura 1: Capa do livro de Atas da Associação de Surdos-Mudos do Estado de São Paulo.

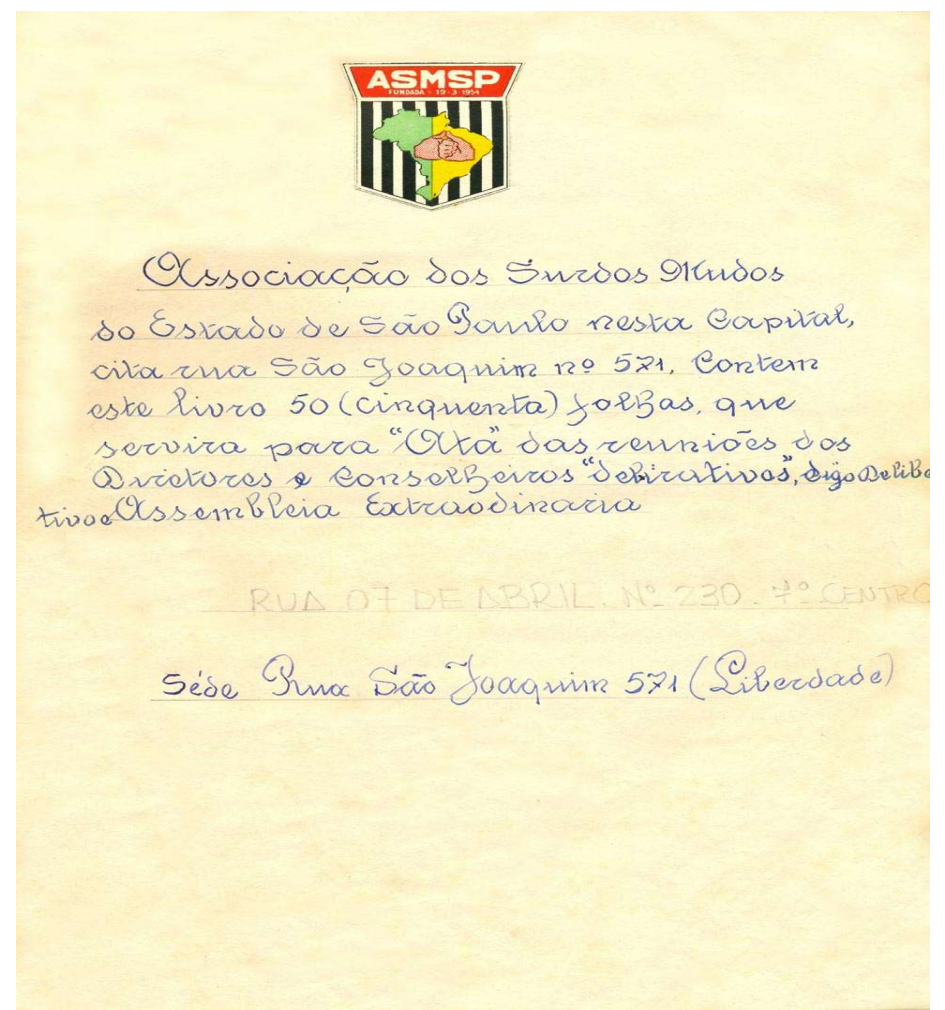

Fonte: Acervo da Associação dos Surdos Mudos de São Paulo - Memorial da inclusão ${ }^{13}$.

A partir da fundação de Associação de Surdos-Mudos de São Paulo é possível observar como foi organizado um sistema de referência de ação coletiva conforme explicado por Melucci (2001). Ou seja, para haver uma ação coletiva, não é necessária a existência de um espaço físico, concreto, mas sim haver a construção de práticas entre diferentes atores sociais. Entende-se, desse modo, que uma ação coletiva pode vir a ser organizada tanto a partir de relações formais quanto informais, estruturando-se nas relações sociais, na medida em que são os próprios grupos de indivíduos que fazem e definem suas ações coletivas.

Segundo Rangel (2004), a Associação de Surdos-Mudos de São Paulo pode ser considerada a primeira associação criada por um grupo de surdos no país, de forma similar à existente em Paris, também organizada apenas por surdos. $\mathrm{O}$ mesmo não pode ser dito

13 Disponível em: <http://www.memorialdainclusao.sp.gov.br/br/exposicoes/tour-virtual/sala-01/ossentidos-na-comunicacao-deficiencia-auditiva/modulo-7-associacao-dos-surdos-mudos-do-estado-de-saopaulo-assp-feneis-cbds-e-copavi-sp/capa-do-livro-de-atas-da-associacao-dos-surdos-mudos-de-saopaulo/>. Acesso em 10 dez. 2016. 
em relação a outras duas associações existentes no Brasil anteriores à ASMSP - a Associação Brasileira de Surdos-Mudos, fundada em 1913 no Distrito Federal e a Associação Alvorada de Surdos, fundada em 1953 no Rio de Janeiro - por serem ambas organizadas por ouvintes.

Reconhece-se, no entanto, que esta mesma compreensão não é consenso entre os surdos, na medida em que Monteiro (2006), de forma contrária, afirmou que a primeira associação de surdos foi organizada no Rio de Janeiro, em 1930, por ex-alunos do grêmio estudantil do Ines, com o objetivo de desenvolver diferentes modalidades esportivas para competição com ouvintes. No entanto, por ter sido formada apenas por um pequeno número de surdos daquela instituição, ou seja, por ser uma organização local, voltada a único fim (desenvolvimento de competições entre surdos e ouvintes), e por não ter tido uma organização envolvendo outros surdos, não se considerou esta iniciativa como sendo a de uma associação. Acrescenta-se ainda que, pelos motivos expostos acima, este grupo, em pouco tempo, se desfez.

Por esta razão, compreende-se, em consonância com Rangel (2004), que a ASMSP foi a primeira associação de surdos do Brasil, por ter sido fundada por e voltada aos interesses dos surdos; uma associação que contou com a participação de pares surdos da cidade de São Paulo e do Rio de Janeiro, além daqueles da Associação de Surdos de Argentina, que já, naquele momento histórico, compreendiam que aquele espaço de convivência das comunidades surdas exerceria

um importante papel, não apenas por ser um lugar de referência e de encontro para as pessoas com deficiência auditiva, mas, fundamentalmente, por ser um lugar onde se criam laços de pertencimento na comunidade surda, a partir da interação humana, possível de ser estabelecida pelo fato de [neste espaço] se compartilhar um código linguístico comum, a língua de sinais ${ }^{14}$ (Tradução nossa) ${ }^{15}$

\footnotetext{
${ }^{14}$ Disponível em: $<$ http://www.vocesenelsilencio.org.ar/modules.php?name=News\&file $=$ article \&sid=58 $>$. Acesso em 15 mai. 2017.

${ }^{15}$ No original: un importante rol, no solo por ser un lugar de referencia y encuentro para las personas con deficiencia auditiva, sino fundamentalmente porque es un lugar donde se crean lazos de pertenencia a la comunidad sorda, a partir de la interacción humana, que les es posible establecer por el hecho de que se comparte un código lingüístico común, la lengua de señas.
} 
Uma associação cuja fundação possibilitou parcerias com surdos de diferentes estados brasileiros, perdurando no tempo, como uma das principais referências nas lutas dos surdos até os dias de hoje, como será discutido no decorrer destas análises.

Retomando a história, a missão da ASMSP e seu protagonismo na história dos surdos brasileiros, pode ser observada logo na primeira ata, da qual se destacam alguns trechos para discussão.

Figura 2: Primeira página da primeira Ata da Associação de Surdos-Mudos de São Paulo.

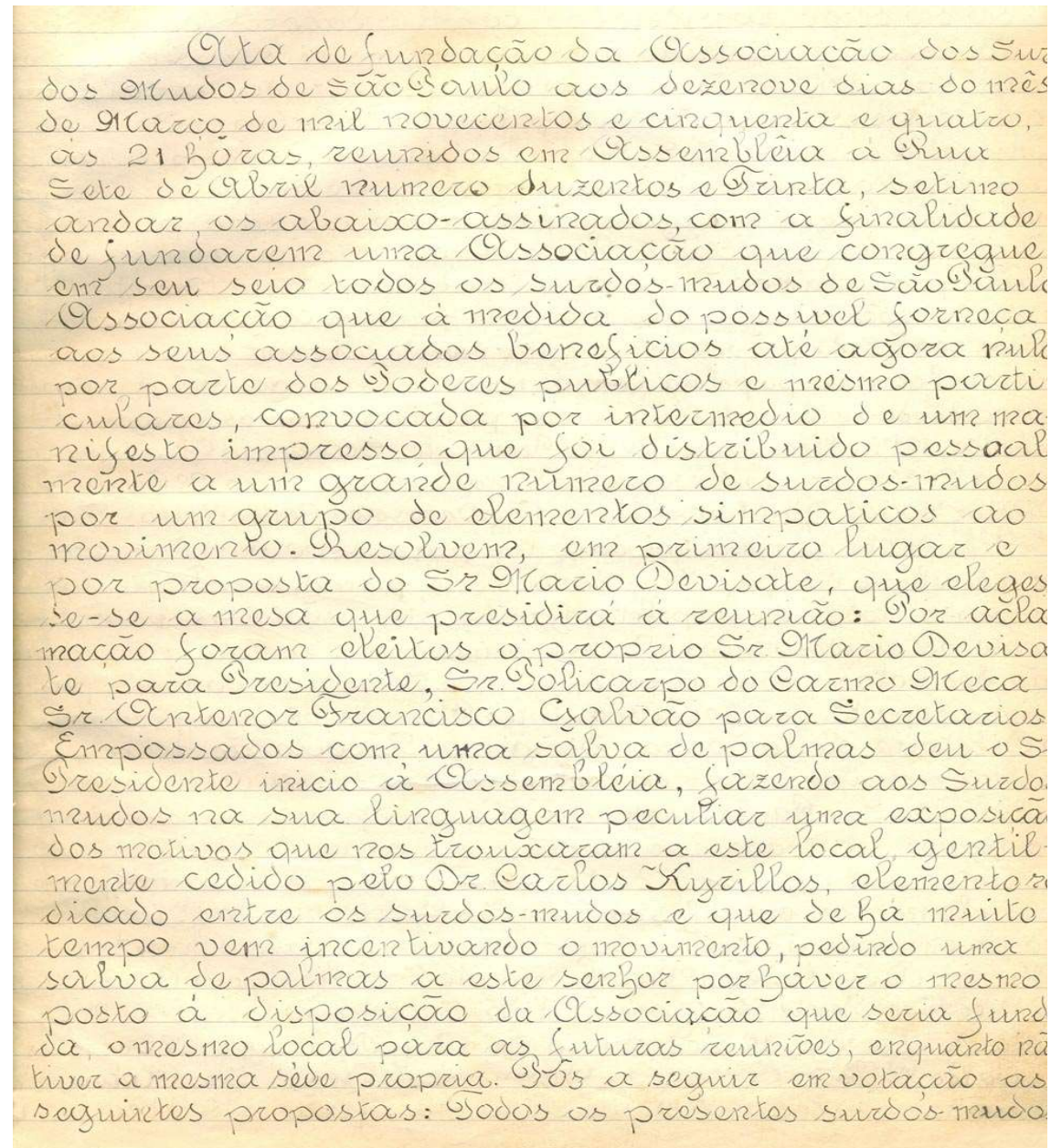

Fonte: Acervo da Associação dos Surdos Mudos de São Paulo - Memorial da inclusão ${ }^{16}$.

O primeiro deles diz respeito à função primeira da Associação:

\footnotetext{
${ }^{16}$ Disponível em: $\quad<$ http://www.memorialdainclusao.sp.gov.br/br/exposicoes/tour-virtual/sala-01/ossentidos-na-comunicacao-deficiencia-auditiva/modulo-7-associacao-dos-surdos-mudos-do-estado-de-saopaulo-assp-feneis-cbds-e-copavi-sp/ata-de-fundacao-da-associacao-dos-surdos-mudos-de-sao-paulo/> . Acesso em 10 dez. 2016.
} 
os abaixo-assinados, com a finalidade de fundarem uma Associação que congregue em seu seio todos os surdos-mudos de São Paulo. Associação que à medida do possível forneça aos seus associados benefícios até agora nulos por parte dos Poderes Públicos e mesmo particulares, convocada por intermédio de um manifesto impresso que foi distribuído pessoalmente a um grande número de surdos-mudos por um grupo de elementos simpáticos ao movimento (...) Empossados com uma salva de palmas deu o Sr. Presidente início à Assembleia, fazendo aos Surdos-Mudos na sua linguagem peculiar uma exposição dos motivos que nos trouxeram a este local (Ênfase adicionada)

Observa-se assim, que a finalidade principal desta Associação era, além do esporte que impulsionou sua fundação, transformar-se em um espaço para que as pessoas surdas de São Paulo pudessem frequentar. No entanto, chamou a atenção desta pesquisadora, o fato de, logo em seguida, ter se assumido que, à medida do possível, seria também função daquele espaço, o fornecimento de benefícios, até então, negados aos surdos pelos Poderes Públicos e pela iniciativa privada. Embora não seja possível afirmar com certeza a quais benefícios se estava fazendo referência no documento, torna-se possível algumas inferências ao se considerar o contexto sócio-histórico que os surdos viviam naquele momento.

As poucas escolas de surdos existentes na cidade de São Paulo tinham suas práticas voltadas, principalmente, para a oralização dos surdos, ou seja, nestes espaços sociais de convivência dos alunos lhes era imposta uma única forma de comunicação: a linguagem oral da língua portuguesa. Para que eles pudessem se encontrar e manter uma comunicação da forma como julgassem melhor a fim de discutir temas de seus interesses, recorriam a pontos de encontros fora dos muros da escola, na grande maioria das vezes, nas ruas do centro de São Paulo. Faltava-lhes, portanto, espaços sociais outros para que pudessem se encontrar e exercer seu direito ao lazer, à cultura, ao esporte, entre outros. A partir da fundação da ASMSP, este espaço passava a existir.

Compreende-se, em consonância com Melucci (1989, 2001), que esta diferença de oportunidades socioculturais entre surdos e ouvintes gerava, mesmo que de forma não explicita, um conflito, que determinava a necessidade de união, de estabelecimento de uma rede de solidariedade a fim de ser possível romper certos limites de compatibilidade dos sistemas sociais. A ASMSP, tornava-se, portanto, um espaço no qual os surdos 
poderiam exercer sua socialibidade ${ }^{17}$, produzindo ações que poderiam definir seus modos de ação coletivos a partir de determinados interesses em comum. Constituía-se, portanto, em um espaço no qual seria possível a manutenção de sua autonomia, tanto individual como coletiva, distanciando-se, de certo modo, das exigências sociais, especialmente no que diz respeito à determinação da língua a ser usada por eles nas relações cotidianas.

Nesse sentido, entende-se a menção presente na ata de que o Presidente, ao expor os motivos da fundação da Associação, fê-lo na linguagem peculiar dos "Surdos Mudos", linguagem esta compartilhada e utilizada por aquele coletivo, apesar da imposição da linguagem oral que vivenciavam em seu cotidiano escolar e familiar (para a maioria dos surdos). Destaca-se ainda não haver, naquele coletivo, uma união visando a oposição à ideologia dominante de tentativa de oralização dos surdos; somente criava-se um espaço para que a comunidade pudesse conviver, construindo, desse modo, um vínculo de pertencimento a uma comunidade. O espaço da ASMSP constituía-se assim, em um local para se compartilhar conhecimentos e informações.

A fundação da Associação pode ainda ser entendida como um espaço de educação não formal, conforme compreendido por Gohn (2005, 2010, 2011), nos quais os surdos podiam partilhar experiências, perspectivas de mundo sob o olhar dos próprios surdos e não mais na perspectiva ouvinte que dominava os espaços sociais que frequentavam. Podiam aprender na convivência, na diferença de histórias que circulavam naquele espaço recém-criado.

Outro ponto que merece destaque diz respeito ao fato do grupo se autodenominar Surdos-Mudos e, portanto, a denominação desta associação como Associação de SurdosMudos de São Paulo. Atualmente, esta referência não é aceita pelos surdos brasileiros. Para nós, surdos, nos dias atuais, o termo surdo-mudo carrega consigo um sentido pejorativo ou ancora-se no discurso da deficiência; entretanto, percebe-se que isso não ocorria na década de 1950: assim os surdos eram chamados e assim se autodenominavam.

Ainda no período de fundação dessa instituição, segunda metade da década de 1950, a sociedade brasileira passava por mudanças significativas de governo, após o suicídio de Getúlio Vargas. Assumia o poder seu vice, o Presidente Café Filho, deposto com um pouco mais de um ano depois de tornar-se presidente. Em seu lugar, assumiu a

\footnotetext{
${ }^{17}$ Segundo Sposito (1993), a sociabilidade é uma forma de socialização entre indivíduos a fim de desenvolverem relações específicas, construir suas identidades coletivas e produzirem ações coletivas para satisfazerem suas necessidades.
} 
presidência, interinamente, Carlos Luz, que permaneceu no poder por apenas três dias, seguido por Nereu Ramos, também como presidente interino, que governou o Brasil por aproximadamente três meses. Em 1956, foi eleito, como Presidente da República, Juscelino Kubitschek de Oliveira (JK), por um período de quatro anos. Kubitschek deu continuidade ao projeto de desenvolvimento econômico iniciado na Era Vargas, consolidando a industrialização no país.

Conforme discutiu Cunha (2002), a resposta aos problemas para o desenvolvimento econômico brasileiro materializava-se, no governo JK, no Programa de Metas por ele traçado, construído a partir de trinta e um itens que envolviam a indústria, o transporte, a alimentação, a geração de energia, a construção de Brasília e a educação. Pode-se dizer ainda, em consonância com Cunha (2002), que este Programa era "imbuído de uma mentalidade que privilegiava a racionalidade na administração pública” (p. 128).

No que diz respeito à área da educação nacional, grande ênfase foi dada por JK às escolas técnico-profissionais, espaços que garantiriam a especialização de pessoas que se tornariam empregados qualificados para o desempenho das funções em setores da produção econômica. Segundo Cunha (2002, p. 132), “Juscelino visualizava um ensino secundário com maiores possibilidades de opções, além da tradicional via de acesso ao ensino superior", razão pela qual reconhecia a necessidade de formação de professores e de técnicos administrativos para este nível de ensino; posteriormente, o magistério primário foi incluído neste rol. Estudos "intelectuais" seriam reservados apenas àqueles que demonstrassem aptidão, espaços que eram ocupados, principalmente, pelas classes sociais mais favorecidas, pois elas poderiam influenciar, positivamente, o desenvolvimento do país. Neste contexto, "entre os anos de 1957 e 1959, os recursos federais destinados aos cursos industriais de nível médio sofreram uma quadruplicação" (CUNHA, 2002, p. 132).

Esta maneira de se compreender a função da educação determinou um aumento no número de atendimento na área da educação especial, realizado, principalmente, pelo setor privado, de caráter filantrópico, como as associações de pais e amigos, ou pagos por aqueles que tivessem condições de fazê-lo. O setor governamental por sua vez, "sob a influência de elementos do ensino especializado, de associações civis, inclusive de deficientes (...) vai promover a área através das campanhas (...) embora [houvesse] críticas a essas formas de desenvolver a educação" (JANNUZZI, 2012, p. 74-75). A 
finalidade destas campanhas era a promoção de medidas voltadas à educação e a assistência, em sentido amplo, aos deficientes, em todo território nacional. A primeira campanha voltou-se à Educação dos Surdos Brasileiros (Cesb), em 1957, como sugestão de Ana Rímoli que ainda estava na direção do Ines.

Neste mesmo ano, a então gestora do Ines substituiu, pela primeira vez, o termo Surdo-Mudo por Surdo, já que o objetivo da educação voltada a este grupo de alunos seria o de libertá-los da mudez e, portanto, leva-los a falar e ler os lábios de seu interlocutor. Segundo Brito (2013, p.25),

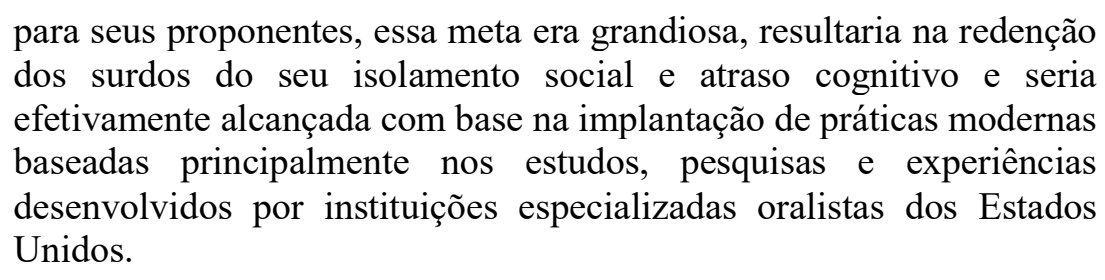

Ainda segundo Brito (2013), apesar da ideologia que subsidiava toda a educação dos surdos, as interações sociais entre os alunos, destes com ex-alunos, com alguns funcionários e professores ocorriam por meio da língua de sinais e, por este motivo, por acreditar na eficácia das técnicas de oralização, Ana Rímoli proibiu, oficialmente, nesta data, a comunicação por sinais nas dependências do Ines, "chegando ao extremismo de decretar medidas para impedir qualquer contato dos novos alunos com os veteranos ou ex-alunos usuários dessa língua sinalizada” (p. 26). No entanto, esta proibição não surtiu os efeitos desejados, na medida em que a língua de sinais continuava sendo a principal forma de comunicação entre os surdos do instituto, embora às escondidas, a fim de serem evitadas advertências e ameaças das autoridades escolares.

A imposição da comunicação oral aos surdos estendia-se também às escolas paulistanas. Esta preocupação, levou o governo de São Paulo a realizar uma reforma administrativa, publicando, em 1958, o Decreto $\mathrm{n}^{\mathrm{o}} 34.380$, por meio do qual criou-se, no âmbito do Departamento de Educação da Secretaria de Educação do Estado, o Serviço de Educação de Surdos-Mudos, cujo objetivo era "prestar assistência educacional a todos os deficientes da audição e da fala no Estado, de nível pré-primário e primário, no sentido de favorecer sua plena integração social" (SÃO PAULO, 1958, Artigo $1^{\circ}$ ). Cabia a este serviço administrar e orientar às classes especiais existentes e a serem criadas, de acordo com a necessidade do Estado (Artigo $2^{\circ}$, Parágrafo único), que estariam sob a 
responsabilidade de professores regentes "recrutados dentre professores habilitados na especialidade" (Artigo $4^{\circ}$ ).

Apesar da imposição da linguagem oral da língua portuguesa na escolarização dos surdos, fora das escolas, a língua de sinais continuava a se fortalecer em função do contato pessoal entre surdos de diferentes cidades e estados brasileiros, contato este favorecido (também) pela ASMSP, que contava com membros do interior paulista e ex-alunos do Ines. Pode-se dizer, desse modo, que a ASMSP teve um papel importante no processo de fortalecimento da Libras, no sentimento de pertencimento a uma comunidade que comungava uma língua em comum, no contato entre pessoas de diferentes faixas etárias. Este fato pode ser observado no depoimento de Sentil Delatorre:

Associações de surdos além de funcionarem como ponto para encontro esportivo dos surdos funcionavam também como divulgadoras da língua de sinais, e como identificadoras da capacidade do surdo como cidadão (FENEIS, 2002, apud RANGEL, 2004, p. 53).

Segundo a entrevista concedida a esta pesquisadora por Mario Pimentel e conforme Abreu (2016), neste período, os campeonatos de futebol entre surdos e ouvintes continuavam; no entanto, a possibilidade de encontro entre surdos propiciado pela ASMSP levou Mario Devisate, então presidente da Associação, a organizar novos jogos, agora apenas entre surdos. Seria uma nova oportunidade para que comunidades surdas de diferentes estados pudessem se encontrar e para a fundação de novas Associações, fundadas com o apoio da ASMSP. Assim ocorreu em $1955^{18}$, no Rio de Janeiro; em 1956, em Belo Horizonte; e posteriormente, em Porto Alegre, Florianópolis, Curitiba e Goiânia.

\footnotetext{
${ }^{18}$ A Sociedade dos Surdos-Mudos do Distrito Federal (SSMDF) foi fundada em 26 de março de 1955, no Rio de Janeiro, e seu estatuto publicado no Diário Oficial, em 29 de setembro do mesmo ano (CABRAL, 2012). A partir da fundação desta associação, foi realizado o primeiro campeonato (histórico) entre surdos do Rio de Janeiro e de São Paulo (Foto 5). Posteriormente, a Sociedade dos Surdos-Mudos do Distrito Federal (SSMDF) fundou a Federação Carioca de Surdos-Mudos (FCSM), em 1959, liderada por Sentil Dellatorre. Atualmente, a Sociedade dos Surdos-Mudos do Distrito Federal é conhecida como a Associação de Surdos do Rio de Janeiro (ASURJ).
} 
Fotografia 3: O primeiro campeonato de futebol entre jogadores surdos de ASMSP e SSMDF em 1956

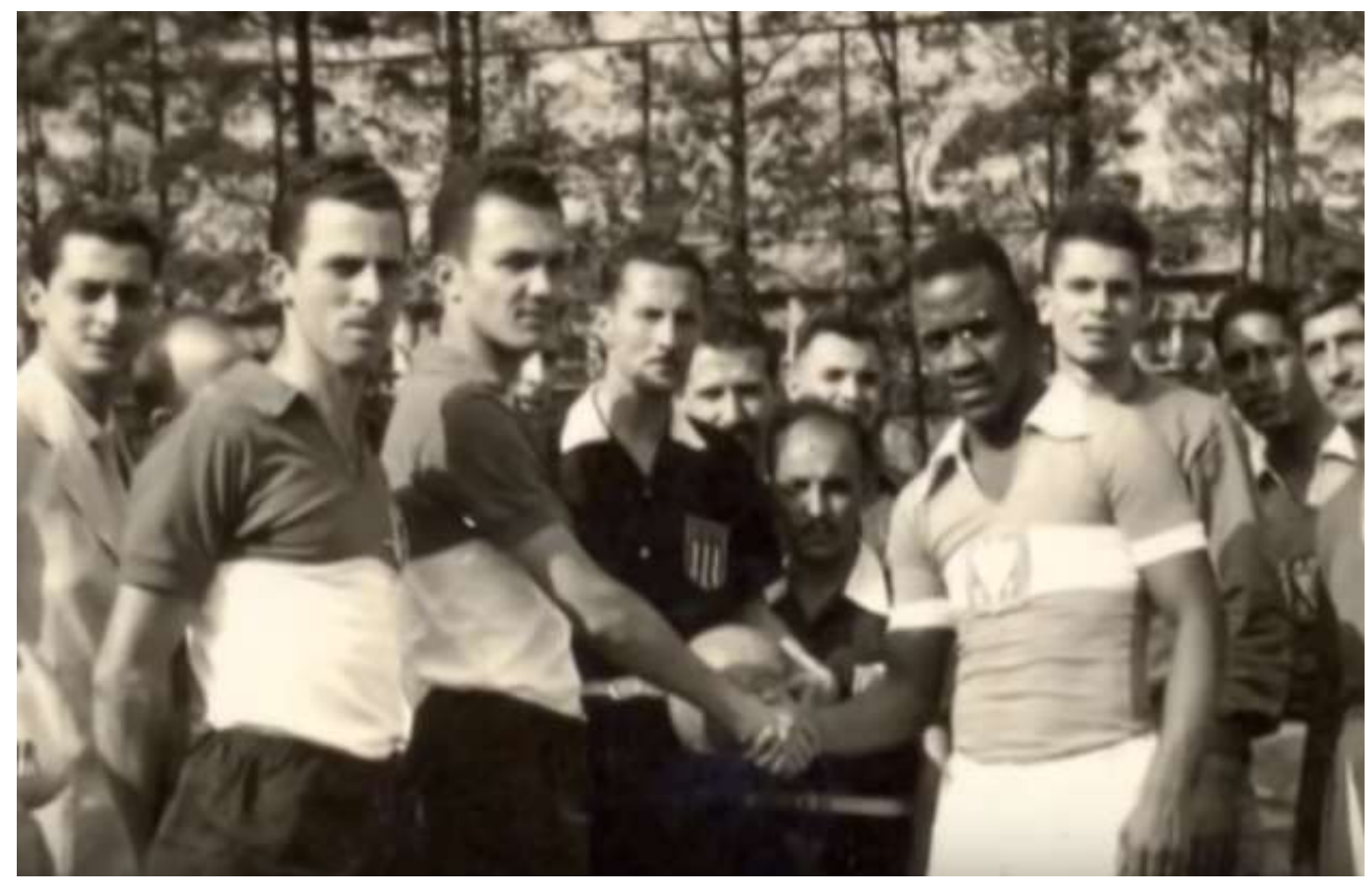

Fonte: História - Esporte dos Surdos e Líderes Surdos CBDS (Abreu, 2016c).

De mãos dadas encontram-se, à esquerda, Mario Pimentel, jogador de ASMSP e à direita Wilson Nascimento, jogador da Associação de Surdos-Mudos do Distrito Federal.

Além da fundação das Associações nas capitais dos estados, outras foram, nesse mesmo período, criadas em cidades do interior paulista, como foi o caso da Congregação Santista de Surdos-Mudos (CSSM), em 1957, atualmente Congregação Santista de Surdos (CSS); da Associação de Surdos-Mudos de Campinas, fundada em 1962 por Armando Melloni, hoje Associação de Surdos de Campinas (Assucamp) e, uma década depois, na cidade de Ribeirão Preto, já com o nome de Associação de Surdos de Ribeirão Preto (ASRP), entre outras. 
Figura 3: Primeira logomarca da CSSM.

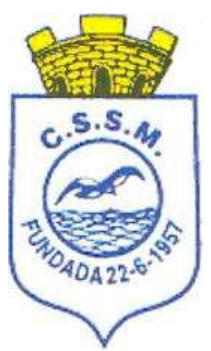

Fonte: Blog da Congregação Santista de Surdos. ${ }^{19}$

Figura 4: Brasão da Assucamp, desenhados por dois artistas surdos

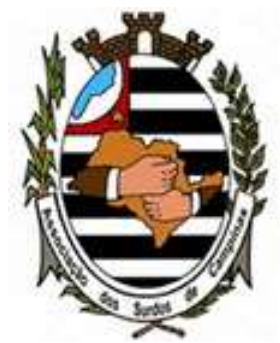

Fonte: Associação dos Surdos de Campinas ${ }^{20}$

\section{Figura 5: Associação de Surdos de Ribeirão Preto (ASRP)}

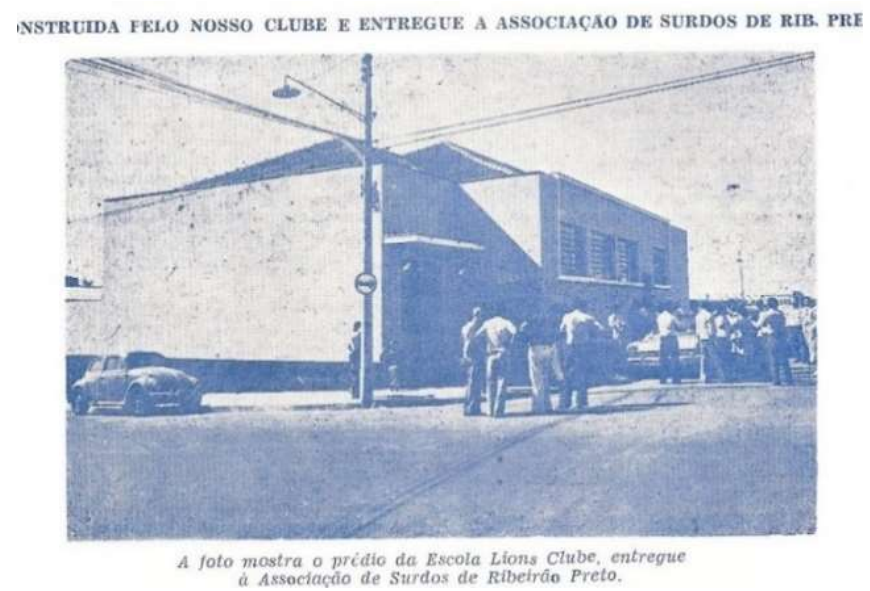

Fonte: Meio Século a Serviços de Ribeirão Preto ${ }^{21}$

Essas Associações, além do caráter esportivo que as motivavam, tornaram-se também, conforme enunciado por Mario Pimentel, a "casa dos surdos", um espaço de

\footnotetext{
${ }^{19}$ Disponível em: $<$ http://congregacaosantistadesurdos.blogspot.com.br/> . Acesso em 15 dez. 2016.

${ }^{20}$ Disponível em: $<\underline{\mathrm{http}}$ ://assucamp.org.br/a_fundacao.html $>$. Acesso em $15 \mathrm{dez} .2016$.

${ }^{21}$ Disponível em: < http://lionscluberpcentro.blogspot.com.br/2009/11/meio-seculo-servico-de-ribeiraopreto.html>. Acesso em 15 dez. 2016.
} 
encontro, de socialização, de elaboração de projetos sociais e de lazer; um local que permitia o compartilhar experiências, conhecimentos, vivências e, desse modo, a construção de aprendizagens. Organizavam-se eventos e ações em prol da manutenção deste espaço e em função destas, ouvintes também passaram a frequentar e participar das atividades desenvolvidas pela ASMSP.

$\mathrm{Na}$ entrevista à este trabalho, Mário Pimentel lembrou que, nos primeiros anos após a fundação da Associação de Surdos-Mudos de São Paulo, um advogado, chamado Florindo, passou a frequentá-la para aprender língua de sinais; seu contato com os surdos foi tal que ele se transformou em uma espécie de "intérprete", escrevendo ou articulando o que ouvintes diziam de forma que os surdos pudessem compreender, além de acompanhar Mario Pimentel em suas viagens para auxiliar outras comunidades surdas à fundarem novas associações, assim como ocorreu em Santos, Campinas, entre outros locais. Lembrou ainda que havia uma delegacia próxima a ASMSP e que os policiais começaram a frequentar aquele espaço para conversar com os surdos e para jogar baralho. Assim, ao aceitar a participação também de ouvintes nas atividades desenvolvidas, a ASMSP atuava como um espaço para que novos olhares sobre os surdos fossem sendo construídos socialmente.

Este aumento de contato com outros sistemas sociais fora da ASMSP, no entanto, não interferiu na autonomia financeira da associação, na medida em que ela não dependia de outras instituições para a obtenção de recursos, visto que, desde sua fundação, contava com a contribuição mensal de seus sócios-fundadores e com arrecadações decorrentes de diversas festividades por ela promovidas, recursos que se mostravam suficientes para a manutenção de seu funcionamento. Em consonância com Melucci (1989), compreendese que o contato com outros grupos sociais contribuia para o estabelecimento de diferentes tipos de relações e de organizações, formais e informais, viabilizando uma rede mais ampla de participantes, ao mesmo tempo em que possibilitava ao grupo de surdos o sentido de pertencimento social e o desenvolvimento de uma identidade coletiva.

Apesar disso, Melucci (2001) alerta que nenhuma ação coletiva é pacífica, porque no decorrer do processo, pode haver perdas de participantes, como no caso de ocorrerem tensões no grupo, por diferentes razões, durante suas práticas cotidianas. Este fato foi também observado na história da ASMSP. 
Na entrevista, Mario Pimentel relatou que na ASMSP não havia a imposição de uma única forma de comunicação e, portanto, além da livre circulação da Libras, aceitavase, naquele espaço, também a linguagem oral do português, fato que possibilitava o estabelecimento de relações interpessoais que aproximava a todos. Pode-se dizer assim, que aqueles que fundaram e lutavam pela manutenção da ASMSP partilhavam uma identidade coletiva, constituíam uma comunidade na qual, por meio da língua, sentiamse pertencentes àquele grupo. E neste processo de construção coletiva de uma "casa dos surdos", onde se podia (também) usar a língua de sinais, havia um pequeno grupo que não a aceitava e defendia a comunicação oral. Houve então o rompimento desses grupos.

Nesta separação, foi fundada a Associação dos Surdos Paulistas ${ }^{22}$ que congregava surdos oralizados que, da mesma forma como ocorria na Associação Alvorada, localizada no estado de Rio de Janeiro, constituída por um grupo "privilegiado" de surdos oralizados, passaram a apoiar o uso da comunicação oral, além de também difundir práticas esportivas a este grupo (RANGEL, 2004). Percebe-se assim, uma tensão determinada pela saída de um grupo de surdos oralizados da ASMSP a fim de organizar outra ação coletiva.

Para Melucci (2001), as tensões nas relações internas do coletivo podem ser compreendidas na medida em que os grupos precisam enfrentar, diariamente, as exigências e contrastes existentes entre eles mesmos; nesse sentido, deve haver o cuidado para que não haja a imposição de uma intenção e o estabelecimento de práticas de continua negociação a fim de ser possível a construção de recursos, materiais, humanos e simbólicos, disponíveis no ambiente. Desse modo, reconhece-se que os atores coletivos da ASMSP e da Associação dos Surdos Paulistas viviam momentos de possibilidades e obstáculos (MELUCCI, 1990), uma tentativa de se chegar a um consenso que fosse bom para todos. Nesses momentos há (como houve entre as Associações de Surdos) tensões, mas da mesma forma tornou-se possível aos coletivos mostrarem seus distintos fins, meios e ambientes, materializado na divergência ou na forma de definição dos objetivos a longo ou curto prazo, nas escolhas dos meios para a consolidação da solidariedade no interior dos grupos ou na manutenção do equilíbrio nas relações de trocas internas ou externas da ação coletiva.

A Associação dos Surdos Paulistas não se manteve por muito tempo e os surdos oralizados voltaram a ser sócios da ASMSP.

\footnotetext{
${ }^{22}$ Não foram encontrados registros documentais da Associação dos Surdos Paulistas.
} 


\section{III.2 Parceria e apoio da ASMSP para a criação das Federações Desportivas de Surdos-Mudos}

Nos primeiros anos da década de 1960, a sociedade brasileira vivia um momento político conturbado devido à troca de presidentes, que permaneciam no poder por um curto período de tempo; mesmo assim, o governo mantinha seus esforços para a expansão industrial nacional e estrangeira em detrimento das questões sociais. Este contexto acabou por determinar diferentes movimentos sociais que lutavam por uma transformação social relativa à melhor distribuição de terras, aumento de salário dos operários, diminuição do poder dos setores privados e aumento dos públicos nas áreas relacionadas à saúde e à educação. Fausto (2009) cita como novos atores sociais no período, as Ligas Camponesas e a União Nacional de Estudantes (UNE). No entanto, o país continuava a vivenciar rápidas mudanças sociais, com o aumento da população e a proliferação da urbanização nas principais capitais brasileiras.

No que se refere à educação, a preocupação era com o aumento do número de estabelecimentos escolares, do primeiro grau até a educação superior, como uma forma de incentivar "oportunidades e matrículas para setores cada vez mais amplos da população" (MARCÍLIO, 2005, p. 235). Entretanto, apesar das expansões das escolas brasileiras, em termos quantitativos, a educação brasileira ainda se encontrava fragilizada. Um exemplo era o grande número de analfabetos ainda existente no país. Segundo Bittar e Bittar (2012), nos anos 1960, quase 40\% dos brasileiros estava nesta condição, razão pela qual, pesquisadores lutavam pela melhoria da educação popular, destinada, principalmente, aos grupos que migravam das zonas rurais (nas quais o número de escolas era bastante reduzido) para as urbanas (MOURA; SILVA, 2013).

Defendia-se ainda, segundo Ghiraldelli (2008), o ensino público, obrigatório, gratuito e de responsabilidade do Estado, pois apesar de algumas reformas educacionais, o governo ainda não tinha conseguido edificar "um sistema nacional das escolas públicas para todos" (BITTAR; BITTAR, 2012, p.158).

Neste contexto foi publicada a primeira Lei de Diretrizes e Bases da Educação Nacional, Lei no 4.024 de 1961, em discussão há treze anos no Congresso Nacional. Segundo disposto nesta lei, a educação era reconhecida como um direito de todos os brasileiros, podendo ser ministrada tanto na escola quanto no lar (Artigo $2^{\circ}$ ), cabendo à 
família a escolha da educação que pretendia oferecer a seus filhos (Artigo $2^{\circ}$. Parágrafo único). Este direito poderia ser assegurado tanto pelo poder público como pela iniciativa privada, cabendo ao Estado fornecer recursos para aquelas famílias que, por comprovada falta de meios, não pudessem arcar com os encargos da educação (Idem, Artigo $3^{\circ}$ ). Além disso, cabia à União a organização do sistema público de ensino em todo território nacional, estendendo "a ação federal supletiva a todos o país, nos limites das deficiências locais" (Idem, Artigo 13).

No sistema educacional proposto por esta Lei, reconhecia-se apenas o ensino primário como obrigatório e que deveria ser ministrado a partir dos sete anos de idade na língua nacional. No caso de estudantes iniciarem a educação após esta idade, classes especiais ou cursos supletivos poderiam ser formados de acordo com o nível de desenvolvimento dos estudantes (BRASIL, 1961, Artigo 27).

Nesta Lei, pela primeira vez, a educação especial (chamada de educação dos excepcionais à época) apresentou-se como uma preocupação, ainda que relativa, do Estado, que buscava integrar os alunos "excepcionais" à comunidade; para isso, dispôsse que esta educação deveria, no que fosse possível, "enquadrar-se no sistema geral de educação" (BRASIL, 1961, Artigo 88). Diz-se uma preocupação relativa porque no artigo subsequente, a LDB/61 aceitava que esta educação fosse também realizada pela iniciativa privada, que receberia "dos poderes públicos tratamento especial mediante bolsas de estudo, empréstimos e subvenções" (Artigo 89). Desse modo, a educação especial poderia se organizar tanto no sistema geral de educação, quando isso fosse possível, ou em instituições privadas especializadas subvencionadas pelo Estado (MAZZOTTA, 2011).

Em 1963, o então presidente João Goulart (1961 a 1964), propôs a "reorganização da rede nacional, de nível primário a médio, voltada a estes estudantes, destinando dois bilhões de cruzeiros para que os programas realizados nas escolas regulares também fossem desenvolvidos nas escolas especializadas" (JANNUZZI, 2012, p. 61), a fim de atender as necessidades educacionais de uma quantidade maior de alunos especiais; entretanto, segundo pesquisa realizada por Jannuzzi (2012), os documentos analisados não refletem a consolidação desta proposta.

No que diz respeito à nomenclatura utilizada - educação dos excepcionais Bueno (2004) explicou que esta pode ser compreendida nos mesmo termos do que mais tarde foi denominada educação especial. Ou seja, visava-se, por seu intermédio, buscar 
uma forma de educação para as crianças tidas como "diferentes" da maioria. No entanto, Jannuzzi (1985 apud BUENO, 2004) teceu críticas ao uso desta terminologia, por acreditar tratar-se, apenas, de uma substituição de denominação. A autora argumentou ainda que o termo excepcional pode ser compreendido como sinônimo de deficiência e/ou retardo mental, ignorando-se, desse modo, o que é específico de cada criança. No mesmo sentido, Mazzotta (1989 apud BUENO, 2004) também criticou o uso desta forma de se referir às crianças deficientes, visto que este termo acabou por determinar um tratamento às crianças assim denominadas, uniforme e homogêneo, desconsiderando-se as diferentes origens sociais e suas especificidades como ponto de partida para o desenvolvimento de seus processos educacionais.

No caso da educação de surdos, este período, assim como o anterior, ainda era caracterizado pela abordagem oralista tanto nas escolas das esferas pública quanto privada e a campanha voltada a expansão da educação desta população iniciada em 1957 , acabou sendo extinta pelo governo federal em 1963 (JANNUZZI, 2012).

A política educacional, na capital paulista na década de 1960, foi fortemente marcada pelo aumento de empresas multinacionais e pelo êxodo rural; este último, "um dos sérios entraves para a expansão da escolarização" (MARCÍLIO, 2005, p. 93), ao considerar as condições de vida da população do campo que chegava à cidade e o pouco acesso a escolarização que tinham naquele espaço social.

Cabia aos Poderes Públicos, a partir da LDB/1961, a implantação de escolas maternais ou pré-escolas e, frente aos poucos subsídios financeiros, tornou-se necessário que a prefeitura de São Paulo estabelecesse convênios com "entidades sociais, para gerenciar equipamentos e para manter vagas em creches particulares" (MARCÍLIO, 2005 , p. 251) para os filhos de trabalhadoras. No que diz respeito ao ensino primário, algumas experiências-piloto passaram a ser desenvolvidas, voltadas, principalmente, à “maioria pertencente a um nível socioeconômico baixo" (MARCÍLIO, 2005, p. 272), na medida em que, pela LDB/1961, os estados e municípios deveriam assegurar, pelo menos, seis anos de escolaridade aos estudantes. Neste contexto, novas parcerias com instituições privadas foram realizadas, destacando-se, segundo Marcílio (2005), aquela realizada com o Sesi e, portanto, voltada ao mercado de trabalho.

O Estado, o município e o Sesi implantaram algumas classes de $5^{\circ}$ e $6^{\mathrm{a}}$ séries na capital de São Paulo. Havia sete Grupos Escolares com classes 
de $5^{\mathrm{a}}$ e $6^{\mathrm{a}}$ series na década de 1960 . Os objetivos eram o de proporcionar uma visão ampla das atividades industriais e comerciais do meio ambiente e suas influencias em nossa economia (MARCÍLIO, 2005, p.272).

Nesta mesma direção, podem ser entendidas as escolas pré-vocacionais instauradas no estado, voltada aos alunos que, após a conclusão do $4^{\circ}$ ano, não desejassem ou não pudessem seguir seus estudos nos cursos ginasiais. Estas tinham como finalidade “dar educação integral aos alunos, orientando-os para a profissão, com cultura mais técnica que livresca, mais prática que teórica” (MARCILIO, 2005, p.273). Compreendese, portanto, que a educação paulista, principalmente pública, privilegiou, neste período, uma escolarização que se voltava à educação profissional.

A partir de 1964, a sociedade brasileira sofreu, novamente, um grande momento de crise política e social, com a tomada do poder pelos militares que, por meio de diversos atos institucionais, privaram a liberdade individual e coletiva dos cidadãos brasileiros, além de pôr fim à estabilidade no emprego. Esse regime determinou o fim da democracia brasileira ao acabar com as eleições diretas para a presidência e para os governadores dos estados e, por intermédio do Serviço Nacional de Informações (SNI), cessou o direito de greve e de quaisquer reivindicações civis, passando a prender e a torturar civis suspeitos a fim de extrair informações sobre aqueles que se opunham ao governo militar (FAUSTO, 2009; JANNUZZI, 2012).

No ano de 1967, nova Constituição Federal passa a viger no país; esta, em consonância com a LDB/1961, manteve a educação como direito de todos os brasileiros, bem como seu oferecimento tanto no lar quanto na escola, que "assegurada a igualdade de oportunidade, deve inspirar-se no princípio da unidade nacional e nos ideais de liberdade e de solidariedade humana" (BRASIL, 1967, Artigo 168). No que diz respeito aos diferentes níveis de ensino, estes se tornaram de responsabilidade dos Poderes Públicos (BRASIL, 1967, Artigo 168, $\S 1^{\circ}$ ), que se responsabilizariam ainda, pelo amparo técnico e financeiro, incluindo-se bolsas de estudos, ao ensino ministrado pela iniciativa privada (Idem, $\S 2^{\circ}$ ).

No que diz respeito ao ensino primário, manteve-se, no texto, que este deveria ser ministrado somente na língua nacional (Idem, $\S 3^{\circ}$, Inciso I), tornando-o obrigatório e gratuito dos sete aos quatorze anos nos estabelecimentos oficiais (Idem, $\S 3^{\circ}$, Inciso II), assim como para os níveis posteriores, no caso de ser provada "falta ou insuficiência de 
recursos", privilegiando-se, no entanto, "o regime de gratuidade pelo de concessão de bolsas de estudo, exigido reembolso no caso de ensino de grau superior" (Idem, $\S 3^{\circ}$, Inciso III). Assim como na Constituição de 1946, dispôs-se sobre a obrigatoriedade das empresas comerciais, industriais e agrícolas de manterem o ensino primário gratuito aos seus empregados e seus filhos (BRASIL, 1967, Artigo 170).

No entanto, o governo militar impôs algumas mudanças no sistema nacional de educação, suspendendo os programas criados pelos grupos populares e implantando novos, com base no modelo educacional americano: a educação tecnocrata, entendida como uma "pedagogia autoritária e produtivista" (FERREIRA JR; BITTAR, 2008, p. 333) e, portanto, voltada para o mundo do trabalho. Entende-se assim, que o objetivo do governo militar também se voltava para o fortalecimento da economia brasileira e para uma educação que visava a formação de mão de obra para a indústria, da mesma forma como os presidentes Getúlio Vargas e Juscelino Kubistchek nos anos anteriores.

No que diz respeito à educação nacional de surdos, o país ainda era fortemente influenciado pelo Ines, cuja preocupação permanecia no viabilizar a oralização dos estudantes em detrimento dos conteúdos pedagógicos. No entanto, seguindo a política educacional brasileira, este instituto criou, em 1963, o Ginásio Industrial Ernest Huet a fim de ser garantido aos alunos surdos o ensino profissionalizante, que seguia, segundo Rocha (2008), o modelo da educação regular. Em 1966 este ginásio passou a ser denominado "Ginásio Orientado para o Trabalho Ernest Huet".

No que se refere ao estado de São Paulo, a partir de 1966, diferentes documentos foram publicados e, neles, torna-se possível observar como a educação especial era então compreendida. Em 1966, por meio do Decreto Estadual $n^{\circ} 47.186$, foi instituído, no âmbito do Departamento de Educação, o Serviço de Educação Especial que englobou as seguintes áreas de atividade: “a) Educação de Deficientes Auditivos; b) Educação de Deficientes Físicos; c) Educação de Deficientes Mentais; d) Educação de Deficientes Visuais" (SÃO PAULO, 1966, Artigo 1º). Competia a este Serviço:

a) o estudo, elaboração e execução de programas que visem dar cumprimento ao disposto nos artigos 88 e 89 da Lei de Diretrizes e Bases da Educação Nacional (Lei Federal n. 4.024, de 20 de dezembro de 1961)

b) a orientação pedagógica e fiscalização das unidades de ensino especial oficial; 
c) propor a criação de novas unidades estaduais de ensino especializados;

d) fiscalizar as unidades escolares especiais, municipais e particulares;

e) dar parecer sobre pedidos de registro de unidades de ensino especial bem como colaborar na realização de exames para o magistério especializado;

f) promover esclarecimento público sobre os vários aspectos da educação da criança excepcional;

g) promover pesquisas, levantamentos estatísticos, censos e inquéritos visando a melhor estruturação do sistema estadual de educação especial;

(...)

i) proporcionar orientação vocacional e encaminhamento das crianças excepcionais que evidenciem condições de ajustamento social e de trabalho;

(...) (SÃO PAULO, Artigo $\left.2^{\circ}, 1966\right)$.

Compreende-se assim, que a educação dos excepcionais, também no estado de São Paulo, visava a educação profissional e que as "condições de ajustamento social" presente no texto do Decreto, no que diz respeito à educação de surdos, implicaria no desenvolvimento da linguagem oral da língua portuguesa.

Dois anos mais tarde, por meio da Lei n ${ }^{\circ} 10.038$, que "Dispõe sobre a organização do Sistema de Ensino do Estado de São Paulo", a educação dos excepcionais, entendida como aquela voltada à criança ou adolescente deficiente ou superdotado, foi assegurada quando estes alunos não se enquadrassem ao processo comum de educação (SÃO PAULO, 1968a, Artigo 64), devendo ser provida por meio de docentes e profissionais técnicos administrativos habilitados, por intermédio de cursos especiais (Artigo 66). Quatro meses mais tarde, por meio do Código de Educação do Estado de São Paulo (Lei $\mathrm{n}^{\mathrm{o}}$ 10.125/68), tornou-se possível a flexibilização curricular “e a articulação horizontal e vertical dos diversos graus e ramos do ensino, tendo em vista atender: I - às diferenças individuais dos educandos, inclusive dos excepcionais" (SÃO PAULO, 1968b, Artigo11).

Em dezembro de 1969, por meio do Decreto Estadual no 52.324, que "Dispõe sôbre a organização da Coordenadoria do Ensino Básico e Normal da Secretaria da Educação, e previdências correlatas", foi prevista, no interior do Departamento de Ensino Básico, uma Divisão de Orientação Técnica, na qual entre outros serviços, foi previsto o de Educação Especial (SÃO PAULO, 1969, Artigo $6^{\circ}$ ). Neste mesmo ano, segundo Mazzotta (2011), foi aprovado o Plano Estadual de Educação para o período de 1970 1971, tendo como uma das metas, o oferecimento de oportunidades educacionais aos 
alunos de diferentes graus de escolaridade, incluindo-se os "excepcionais do físico, dos sentidos e da inteligência e aos que não tiveram acesso à escola nas idades próprias" (MAZZOTTA, 2011, p. 183).

Entende-se, portanto, em consonância com Mazzotta (2011) que, embora a educação estadual, por meio dos documentos citados, visasse se alinhar à LDB, organizando serviços em áreas especializadas, poucas informações proveem a respeito de como deveria se dar a educação dos excepcionais de forma geral e dos surdos em especial $^{23}$.

Distanciada, em termos de ações, do que ocorria na esfera educacional, a ASMSP mantinha suas práticas esportivas e recreativas. Os surdos que dela faziam parte, continuavam se encontrando; mantinham contato com a Associação da Argentina e ampliavam seu convívio com surdos e associações de diferentes regiões brasileiras, prosseguindo com o foco nas atividades relacionadas ao esporte, como pode ser observado na entrevista de Mario Pimentel: a ASMSP, em uma nova ação coletiva, estabeleceu parceria com a Federação Carioca de Surdos-Mudos, liderada por Sentil Dellatorre, a fim de ser criada a Federação Silenciosa Desportiva Paulista. Inicialmente, Mario Pimentel e Sentil Dellatorre queriam criar essas Federações para que os atletas surdos de São Paulo e Rio de Janeiro participassem de competições esportivas, mas logo pensaram também na criação de uma Confederação de esporte para que todos os atletas, de diferentes estados brasileiros, participassem do esporte nacional. Para que isso acontecesse, Mario Pimentel e Sentil Dellatorre convocaram todas as associações de surdos brasileiras existentes para uma reunião, com o objetivo de se ter um número de adesões suficientes para a criação da Confederação Brasileira de Desportos de Surdos (CBDS).

Deste modo, após a aprendizagem e orientação da Asociación de Sordosmudos de Ayuda Mutua (ASMAM) e a fundação de Associação de Surdos-Mudos de São Paulo (ASMSP), outras ações coletivas tiveram início, responsáveis pelo continuo fortalecimento de uma identidade coletiva, construída nas distintas relações sociais que iam, gradativamente, sendo estabelecidas: surdos de diferentes gerações e origens sociais

\footnotetext{
${ }^{23}$ Nas fontes pesquisadas não foram encontradas informações relativas à educação de surdos na cidade de São Paulo, a partir da segunda metade da década de 1960.
} 
que, pouco a pouco, acumulavam e trocavam experiências, estabelecendo novas relações sociais entre seus membros.

Mario Pimentel, dirigente da Federação Silenciosa Desportiva Paulista, e Sentil Dellatorre, dirigente da Federação Carioca de Surdos-Mudos (FCSM), foram então, ao Conselho Nacional de Desportos (CND) para solicitar autorização para a fundação da CBDS, porém, foram orientados de que, para a criação de uma Confederação, era necessária a parceria de, no mínimo, três Federações. Em nova ação coletiva, os dirigentes surdos trabalharam, junto à direção da Associação de Surdos de Minas Gerais, representada na época pelo surdo Antônio Campos de Abreu, para a criação da Federação Desportiva de Surdos de Minas Gerais.

Embora tenham conseguido organizar a documentação para o Conselho Nacional de Desportos a partir da criação das três Federações, Mario Pimentel e Sentil Dellatorre resolveram juntar outros documentos e solicitar, à Comissão Internacional dos Esportes de Surdos $(\mathrm{CISS})^{24}$, o reconhecimento das três Federações Desportivas de Surdos do Brasil para que seus membros pudessem participar também do esporte internacional. Para que conseguissem o certificado da CISS, Mario Pimentel e Sentil Dellatorre contataram diferentes associações de surdos do Brasil a fim de arrecadar verbas para o pagamento desta certificação, o que veio a ocorrer em 1965.

Figura 6: A logomarca de Comissão Internacional de Esporte de Surdos

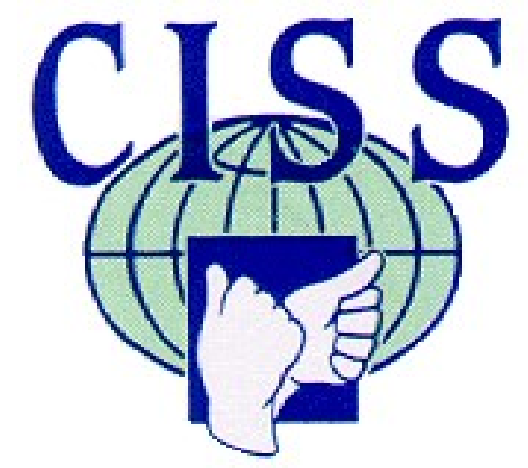

Founded in 1924

Fonte: DIFA

\footnotetext{
${ }^{24}$ No histórico do Comité International des Sports des Sourds consta que ele foi fundado pelo ciclista surdo Eugène Rubens-Alcais com o objetivo de criar jogos internacionais entre surdos, segundo o modelo das olimpíadas modernas, em 1924, na França. Disponível em: $<$ http://www.difa-org.com/history $>$. Acesso em 15 abr. 2017.
} 


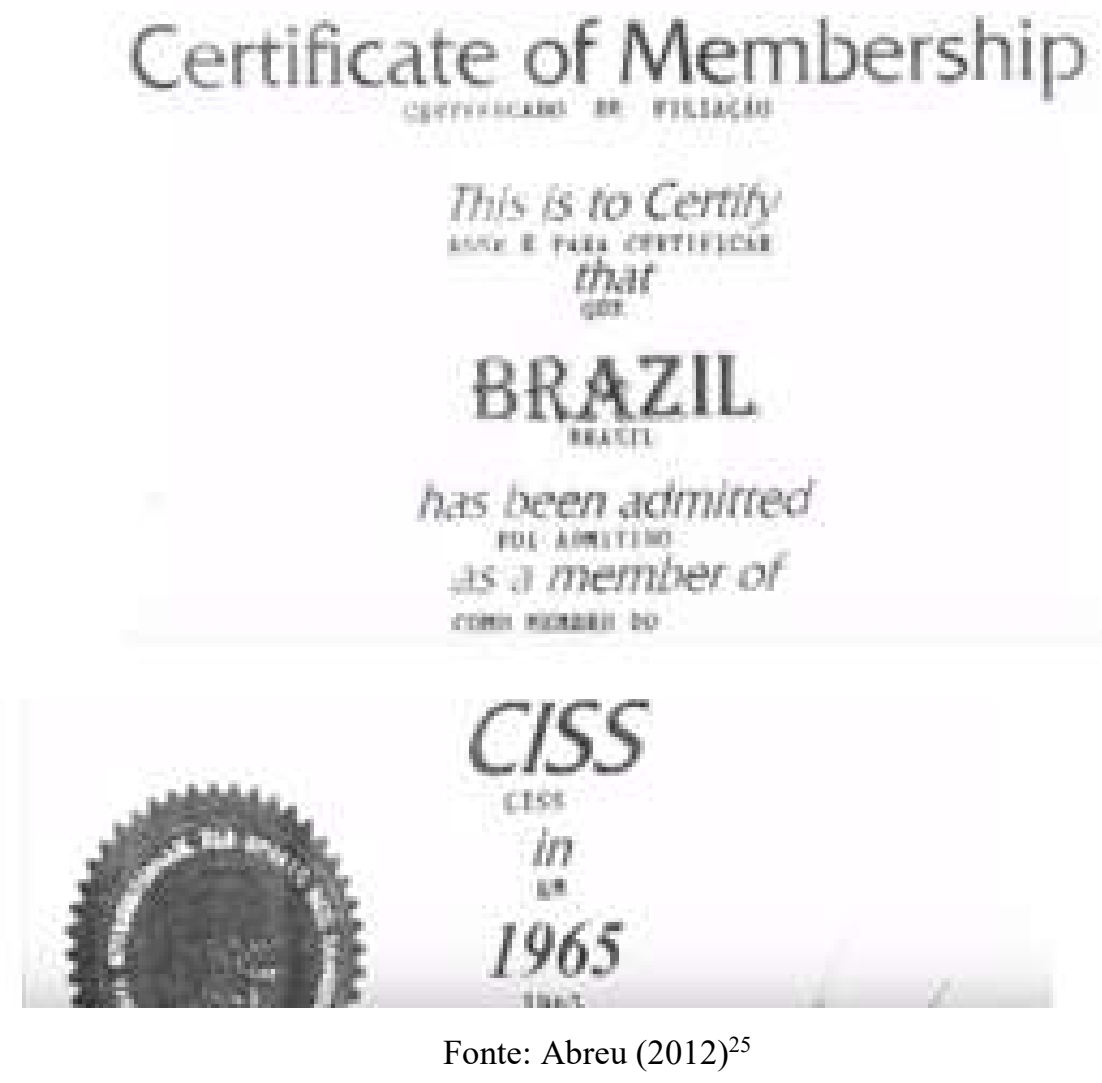

\section{III.3 Apoio da ASMSP ao processo de criação da Confederação Brasileira Desportiva de Surdos (CBDS) e a luta contra a Federação Nacional de Educação e Integração dos Deficientes Auditivos (Feneida)}

Ao longo dos anos de 1970, a sociedade brasileira vivia um momento muito tenso por conta das diversas restrições sociais e políticas impostas pelo governo militar, como a interrupção dos direitos de voto dos brasileiros e da livre expressão de pensamento. Apesar disso, a economia brasileira se expandia, sobretudo com o crescimento das instalações das indústrias automobilísticas no país e com o comércio exterior. No entanto, dada a grande dívida interna e externa existente, muitos programas sociais sofreram cortes; como consequência, o país passou a oferecer baixas condições sociais à população nas áreas da saúde, educação e habitação, cujos reflexos puderam ser sentidos nos

\footnotetext{
${ }^{25}$ Disponível em: $<$ https://www.youtube.com/watch?v=_C0ABUU31Qs\&t=122s $>$. Acesso 28 abr. 2017.
} 
indicadores mundiais "que medem a qualidade de vida de um povo" (FAUSTO, 2009, p. 269).

Nesse contexto, o governo militar implantou reformas na educação brasileira, previstas na Lei $n^{\circ}$ 5.692, que Fixa Diretrizes e Bases para o Ensino de $1^{\circ}$ e $2^{\circ}$ graus, publicada no dia 11 de agosto de 1971. Por meio desta Lei, os antigos cursos primário e ginasial, agora chamado de $1^{\circ}$ grau, passou a ter duração de oito anos (720h anuais), tornou-se obrigatório, e devia seguir "um núcleo comum, obrigatório em âmbito nacional", assim como "uma parte diversificada para atender, conforme as necessidades e possibilidades concretas, às peculiaridades locais, aos planos dos estabelecimentos e às diferenças individuais dos alunos" (Artigo $4^{\circ}$ ). O antigo curso colegial, denominado na Lei de $2^{\circ}$ grau, tornou-se também obrigatório. Todos os níveis de ensino deveriam, obrigatoriamente, ser ministrados na língua nacional (BRASIL, 1971, Artigo $1^{\circ}, \S 2^{\circ}$ ).

No entanto, reconhece-se nesta legislação, que a preocupação com a educação se manteve ainda voltada à formação profissional, como pode ser lido no caput do Artigo $1^{\circ}$ da Lei: "O ensino de $1^{\circ}$ e $2^{\circ}$ graus tem por objetivo geral proporcionar ao educando a formação necessária ao desenvolvimento de suas potencialidades como elemento de autorealização, qualificação para o trabalho e preparo para o exercício consciente da cidadania”. Segundo Marcílio (2005), embora o número de anos escolares tenha sido prolongado a fim de propiciar aos alunos um tempo maior na escola, este fato pouco alterou a realidade educacional brasileira, na medida em que o modelo pedagógico do novo sistema nacional de educação mantinha-se voltado ao mundo do trabalho. Marcílio (2005) apontou ainda alguns prejuízos na reforma realizada por meio da Lei de1971:

Foi implantada uma desastrosa profissionalização da escola média, prejudicando seriamente sua organização durante toda a década de 1970, antes de sua revogação na década seguinte. Foi igualmente desastrosa quando liquidou a Escola Normal, rebaixando a formação de professores primários para uma "habilitação" especial de grau médio. Desde então o preparo do professor de escola infantil e do $1^{\circ}$ grau fundamental não encontrou mais uma organização conveniente (MARCÍLIO, 2005, p. 244).

No que diz respeito à educação especial, encontrou-se, naquela Lei, apenas um Artigo, cuja disposição voltava-se, especificamente, aos deficientes físicos ou mentais e aos superdotados: 
Art. $9^{\circ}$ Os alunos que apresentem deficiências físicas ou mentais, os que se encontrem em atraso considerável quanto à idade regular de matrícula e os superdotados deverão receber tratamento especial, de acordo com as normas fixadas pelos competentes Conselhos de Educação (BRASIL, 1971).

Apesar de apenas esse artigo fazer referência a parte dos educandos da educação especial, segundo Mazzotta (2011), o Ministério da Educação e Cultura (MEC), no ano seguinte à publicação da Lei no 5.692 , solicitou parecer ao Conselho Federal de Educação (Parecer CFE $n^{\circ}$ 848/72) relativo à necessidade de maiores recursos financeiros a fím de serem equacionadas as questões relacionadas à educação dos excepcionais. Nesse contexto, foi constituído um grupo de trabalho, designado "Grupo-Tarefa de Educação Especial" que, tendo como base o Parecer do CFE, buscou planejar uma "política e as linhas de ação do governo na área da Educação de Excepcionais" (MAZZOTTA, 2011, p. 58). Este Grupo foi gerenciado pelo Instituto Nacional de Estudos e Pesquisas (Inep), subordinado ao MEC, e composto pelos diretores executivos das ainda existentes Campanha Nacional de Educação de Cegos e Campanha Nacional de Educação e Reeducação dos Deficientes Mentais, além de outros profissionais da educação, com o objetivo de elaborar o "Projeto Prioritário n. 35" (MAZZOTTA, 2011, p. 58) que se inseriria no Plano Setorial de Educação e Cultura no período de 1972 e 1974.

No decorrer dos trabalhos do Grupo houve a visita ao Brasil de um especialista em educação especial norte-americano, que apresentou um "Relatório de Planejamento para o Grupo-Tarefa de Educação Especial do Ministério da Educação e Cultura" (MAZZOTTA, 2011, p. 59), que passou, também, a ser objeto de estudo daquele coletivo. A partir deste estudo, o Grupo-Tarefa propôs a criação do Centro Nacional de Educação Especial (Cenesp), que se tornou realidade por meio do Decreto $n^{\circ} 72.425$, de 3 de julho de 1973.

O Cenesp tinha como objetivo "promover em todo o território nacional, a expansão e melhoria do atendimento aos excepcionais" (BRASIL, 1973, Artigo 1º), proporcionar oportunidades educacionais, propor e implementar estratégias a fim de orientar a educação especial "nos ensinos de $1^{\circ}$ e $2^{\circ}$ graus, superior e supletivo, para os deficientes da visão, audição, mentais, físicos, educandos com problemas de conduta, para os que possuam deficiências múltiplas e os superdotados, visando sua participação progressiva na comunidade" (Idem, Artigo $2^{\circ}$ ). Como órgãos subordinados ao Cenesp, 
encontravam-se o Instituto Benjamin Constant (IBC) e o Instituto Nacional de Educação de Surdos (Ines).

No que diz respeito à educação dos surdos, segundo Rocha (2008), em 1974, o MEC/Cenesp, com o intuito de discutir a formação de professores especializados, promoveu, nas dependências do Ines, o "I Seminário Brasileiro sobre Deficiência Auditiva", evento que contou com a participação de profissionais do Brasil, Venezuela e França. Neste Seminário foram tiradas algumas sugestões e recomendações relativas ao tema tratado, que foram encaminhadas ao MEC. Entre elas, Rocha (2008) destacou a necessidade de se envidar maiores esforços para que a formação de professores para os “deficientes auditivos" ocorresse nos Cursos de Pedagogia (habilitação em Educação dos Deficientes da Audio-Comunicação - Edac) e para a promoção de "cursos, conferências, seminários, publicações" (p. 112), em âmbito nacional, para uma constante atualização e aperfeiçoamento dos professores especialistas. No contexto do Seminário, segundo Rocha (2008), houve ainda a sugestão de que fosse proibida a seleção dos "deficientes auditivos" nos cursos de professores especialistas em função do distúrbio de linguagem e da audição que apresentavam, mas esta não foi aceita pela maioria dos presentes. Tornase possível compreender esta proposta ao se considerar o contexto histórico em que o Seminário fora realizado, período no qual o foco da educação dos surdos ainda se centrava na fala.

Importante salientar que, acompanhando iniciativas iniciadas em 1960 em alguns estados do Brasil voltadas à formação em Educação Especial, formação esta que em 1972, passou a ser pensada para a educação superior (Cursos de Pedagogia), no ano de 1973, foi implantada a primeira habilitação em Edac no Curso de Pedagogia da Pontifícia Universidade Católica de São Paulo (DEIMLING, 2013).

No que se refere à educação na capital paulista, Sposito (1993) discutiu que, mesmo com todas as restrições de direitos impostas pelo governo militar, alguns grupos sociais resistiam e organizavam movimentos reivindicatórios, como por exemplo, as Sociedades Amigos de Bairro (SABs) ${ }^{26}$, que lutavam pela abertura de novas creches,

\footnotetext{
${ }^{26}$ Segundo Brant (1983), na segunda metade de 1960 e primeira metade de 1970, alguns desses movimentos conseguiram se manter, na medida em que prevalecia "laços primários de solidariedade na sobrevivência diária da população. Relações de vizinhança, parentesco, compadrio ou amizade, permitiram a proteção imediata dos indivíduos diante de um clima social de medo. Foi em boa parte o desenvolvimento desses laços diretos entre pessoas, que confiavam umas nas outras, que deu origem a vários movimentos" (p. 13) posteriores.
} 
escolas municipais e parques infantis, principalmente nas regiões de periferia da cidade, locais que vivam grande escassez e precariedade na educação pública.

No que se diz a respeito da educação especial no estado de São Paulo, a fim de se adequar às disposições da Lei $n^{\circ}$ 5.692/71 e também de acordo com o Plano Estadual de Educação de 1969, o Conselho Estadual de Educação aprovou a Deliberação CEE n ${ }^{\text {o }}$ 13/1973 que visou fixar “normas gerais para a educação dos excepcionais". Esta, além de caracterizar aqueles que seriam considerados excepcionais, estabeleceu que os alunos só poderiam assim ser considerados mediante caracterização desta condição "por profissionais credenciados que recomendem a conveniência de encaminha-lo[s] a educação especial" (SÃO PAULO/CEE, 1973, Artigo 1º,$\S 2^{\circ}$ ). Estes alunos deveriam ter sua escolarização no regime comum de ensino, podendo ser atendidos em regime especial caso não pudessem se beneficiar da escolarização comum (Artigo $4^{\circ}$ ).

No que se refere ao currículo da educação especial, este deveria seguir o disposto na Lei $\mathrm{n}^{\mathrm{o}}$ 5.692/71, havendo a possibilidade de sua ordenação conforme cada excepcionalidade, "por níveis de desenvolvimento do aluno, sem correspondência necessária com séries anuais" (Artigo $5^{\circ}$ Parágrafo único). Estabeleceu-se ainda que esta educação deveria ser realizada por professores especializados em cursos da educação superior, havendo ainda a possibilidade de esta ocorrer, quando necessário, em cursos de segundo grau.

No Plano de Atendimento à Educação Especial (PAEE) para o período de 1972 a 1975, previu-se, no que diz respeito à formação dos cento e quarenta e cinco professores da rede estadual que atuavam com deficientes auditivos, cursos de aperfeiçoamento para a "interpretação de diagnóstico audiológico, utilização de técnicas de treino auditivo e de manipulação de aparelhos (individuais e coletivos) de amplificação sonora" (MAZZOTTA, 2011, p. 190), seguindo, desse modo, as práticas previstas pela perspectiva oralista de educação de surdos. No entanto, de acordo com o que foi discutido por Mazzotta (2011), dadas as carências de recursos humanos, materiais e institucionais, esta formação não foi realizada como prevista, razão pela qual, no Plano de Atendimento à Educação Especial para 1975-1979, a fim de se conseguir uma maior formação e capacitação de pessoal especializado, foram estabelecidos convênios com Universidades que ofereciam cursos de Pedagogia com habilitações voltadas à formação de professores 
para o ensino de deficientes auditivos, físicos, mentais e visuais para novecentos professores.

A Secretaria da Educação de São Paulo, em 1977, publicou novo Plano Estadual de Educação no qual os PAEEs de 1972-1975 e 1975-1979 foram revistos e atualizados. No entanto, foi mantida a necessidade de diagnóstico médico e psicológico dos alunos excepcionais a fim de auxiliar os professores na organização e/ou suplementação do currículo das classes, como forma de eliminar ou minimizar os "obstáculos que cerceiam ou podem cercear o desempenho do aluno na situação comum de ensino" (MAZZOTTA, 2011, p. 193).

Observa-se assim, que a educação dos excepcionais prevista pelo estado de São Paulo no decorrer da década de 1970, foi moldada a partir de um trabalho médicopedagógico, por meio do qual a "deficiência" tornava-se o centro da atenção e o foco a ser "tratado". No caso dos surdos, a perda de audição e as "dificuldades de fala" sobressaiam-se em detrimento do conhecimento escolar.

Diante desse cenário, espaços de formação extraescolares constituíam-se os únicos nos quais os surdos poderiam se encontrar e se comunicar sem haver a imposição da linguagem oral da língua portuguesa, bem como realizarem atividades esportivas e de recreação. Este era o caso da ASMSP, nos quais seus membros tinham oportunidade de se comunicar livremente e de conhecer surdos de diferentes lugares, como pode ser observado em relatos sobre as ações desta instituição na década de 1970.

Segundo Abreu (2016f), após a certificação do CISS, as três Federações Desportivas de Surdos-Mudos, dirigidas respectivamente por Mario Pimentel (São Paulo), Sentil Dellatorre (Rio de Janeiro) e Antônio de Abreu (Minas Gerais), reuniramse para elaborar o estatuto da Confederação Brasileira de Desportos de Surdos (CBDS). Para isso, várias associações de surdos, de diferentes estados brasileiros, foram convocadas para participarem de uma primeira assembleia, cuja finalidade era a de obter votos para a elaboração de uma proposta de estatuto e para os cargos provisórios da futura Confederação. Esta assembleia foi realizada no dia 7 de setembro de 1979, no Instituto Nacional de Educação de Surdos. Com mais este documento em mãos, a solicitação para a criação da CBDS foi encaminhada ao Conselho Nacional de Desportos, aprovação que só ocorreu na próxima década. 
Paralelamente a este movimento, na segunda metade da década de 1970, conforme discutiu Brito (2013), houve outro movimento no contexto brasileiro, liderado por um grupo de ouvintes: a criação da Federação Nacional de Educação e Integração do Deficiente Auditivo (Feneida), localizada no Rio de Janeiro, em 1977. Esse grupo era formado por profissionais do Ines e por representantes de instituições de outros estados brasileiros, e tinha como o objetivo estimular a fala dos surdos e de orientar às escolas sobre a compra de aparelhos de amplificação sonora. Compreende-se, assim, o porquê da Feneida não ter representantes surdos: para seus fundadores os surdos eram "incapazes de opinar e decidir sobre seus próprios assuntos" (SOUZA, 1998, p. 91).

\section{4 A fundação de Confederação Brasileira Desportiva de Surdos (CBDS) e a criação da FENEIS.}

No início dos anos de 1980, o governo militar no Brasil enfrentava vários problemas de ordem econômica, política e social buscando, sem sucesso, medidas para reverter este cenário. Neste contexto, o Congresso Nacional deliberou pela abertura de novos partidos políticos a fim de encontrar soluções para os problemas sociais o mais rapidamente possível; foram, justamente, alguns desses novos partidos, de oposição ao governo militar, que possibilitaram à sociedade brasileira a retomada de reivindicações e a organização de ações coletivas, de mobilizações civis, que tentavam pressionar os Poderes Públicos a tomarem medidas a fim de reverter, principalmente, os problemas sociais que só aumentaram no país no decorrer do período da ditadura. Um desses movimentos lutava pelas eleições diretas, pela deposição do governo militar e pela volta da democracia (FAUSTO, 2009).

A educação brasileira, neste período, ainda enfrentava uma alta taxa de analfabetismo, de evasão e de repetência escolar e os indicadores apontavam para a baixa qualidade da educação básica oferecida às crianças e jovens brasileiros. Soma-se a isso, a falta de construção e de instalação de creches nas regiões mais periféricas durante o período militar, fato que determinou diversos movimentos reivindicatórios populares, apoiados pela Igreja Católica e pelo Partido dos Trabalhadores (MARCÍLIO, 2005).

Esta pouca qualidade na área da educação envolvia também os processos educacionais oferecidos aos surdos, educação que, segundo Brito (2013), partia do discurso hegemônico que se pautava fortemente 
no modelo individual de deficiência [que se ancorava] no viés médico de cura da surdez. Desse modo, estabelecia-se a oralização como principal meta de ensino, atribuindo os casos de fracasso a problemas de ordem pessoal dos estudantes, tais como insuficiência cognitiva, transtornos psicológicos e fatores biológicos (p. 99).

Apesar disso, como anunciado desde 1979, o ano de 1981 foi considerado, para a Organização das Nações Unidas (ONU), o Ano Internacional das Pessoas Deficientes (AIPD), que tinha como lema "participação plena em igualdade de condições" (BRITO, 2013, p.89). Ainda segundo o autor,

As diversas ações previstas implicaram a mobilização de programas e agências especializadas da ONU que passaram a investir recursos e expertise no delineamento, financiamento e realização de vários projetos e eventos. $\mathrm{O}$ objetivo principal dessas iniciativas era despertar a atenção dos governos e da sociedade civil dos países-membros para a importância de reconhecer e efetivar direitos para as pessoas com deficiência. Diversos materiais que divulgavam novos dados e concepções sobre a deficiência, assim como os direitos desse segmento populacional, foram publicados e distribuídos gratuitamente e em larga escala para vários países do mundo (p. 89).

Este fato mobilizou, também aqui no Brasil, alguns movimentos das pessoas com deficiência, que foram, de acordo com Brito (2013), de grande importância para o incentivo e conscientização desses grupos sociais quanto à necessidade de assumirem uma posição política, compreenderem, participarem e organizarem ações coletivas com pautas reivindicatórias a fim de assegurar seus direitos. Conforme expôs o autor, estes movimentos se intensificaram após o governo brasileiro, ao determinar a instalação da Comissão Nacional do AIDP no ano de 1980, ter escolhido como representantes das instituições sociais e não governamentais, apenas pessoas sem deficiência; mas em decorrência da pressão sofrida, o governo federal acabou cedendo e escolheu um representante e um consultor com deficiência ligado ao movimento.

Os movimentos das pessoas deficientes voltavam-se, principalmente, contra a forma pela qual foram historicamente olhados e concebidos: como "objeto de pena, devido à tragédia pessoal que [os] acometera” (BRITO, 2013, p.95), visão esta que os reduzia "à condição de paciente que precisava ser diagnosticado e tratado para ser curado ou reabilitado" (Idem). Neste momento, passaram a se autodefinir como pessoas 
diferentes, com os mesmos direitos que teriam quaisquer cidadãos brasileiros. Esse novo contexto determinou a criação de organizações e a promoção de três Encontros Nacionais das Pessoas Deficientes ainda no início da década. Poucos surdos estiveram presentes no primeiro encontro, ocorrido em 1980; no entanto, entre eles, estava Antônio de Abreu, presidente da Associação de Surdos de Minas Gerais (ASMG). Neste momento, foi feita, pela primeira vez, a reivindicação ao direito ao uso da linguagem mímica, ao se considerar que muitos surdos apresentavam problemas de aprendizagem em decorrência da imposição da oralização nos espaços escolares.

No segundo encontro, realizado em 1981, o evento contou com uma maior participação de pessoas surdas. Destaca-se, entre eles, Antônio de Abreu e Ana Regina e Souza Campello, surdos que lutavam, junto com Mario Pimentel, para a fundação da CBDS. Nesse segundo encontro, novamente foi feita a reivindicação do direito ao uso da linguagem mímica "basicamente como um meio de garantir, às pessoas surdas não oralizadas, o acesso à informação, à educação e ao atendimento nas instituições públicas e privadas" (BRITO, 2013, p.104). Observa-se, no entanto, que o uso da língua de sinais (então chamada de linguagem mímica) era pensado, quase que exclusivamente, para aqueles surdos que não utilizavam a linguagem oral; nesse sentido, não se compreendeu ter havido uma oposição marcada dos representantes surdos contra o discurso dominante de que eles deveriam ser "normalizados", transformando-se em ouvintes usuários do português oral.

No terceiro Encontro Nacional, em 1983, houve a proposta de se pensar uma organização nacional única para a defesa de todos os deficientes; entretanto, neste evento, os surdos mostraram-se contrários a esta ideia, alegando que as lutas e os objetivos dos diferentes grupos sociais de deficientes não eram homogêneos. Foi então proposta e aceita a criação de "federações nacionais por tipo de deficiência" (BRITO, 2013, p. 108). De acordo com Brito (2013), muitos surdos que participaram desse terceiro encontro estavam envolvidos com as Federações e Associações de Surdos existentes no país, e começaram a convocar surdos para compor uma Comissão Nacional de Luta pelos Direitos dos Deficientes Auditivos a fim de ser criada a Federação Nacional dos Deficientes Auditivos, além de serem organizadas pautas de reivindicação sobre seus direitos, entre elas o uso da linguagem mimica nos processos educacionais. Lembraram-se, então, da existência da 
Feneida, instituição que, além de não se verem representados, passava por diversos problemas financeiros causados pela falta de pagamento das taxas pelos seus filiados.

Observa-se assim, que três importantes movimentos surdos começaram a se delinear no mesmo período da história, tendo como protagonistas pessoas que participavam de todos eles: a luta pelo reconhecimento da língua de sinais nos espaços escolares, a representação dos surdos na Feneida, e a criação da CBDS, ainda não aprovada pelo CND.

No que diz respeito ao primeiro movimento, os surdos assistiam a um novo momento na educação de seus pares no país: a adoção da Comunicação Total, filosofia de trabalho que teve origem nos Estados Unidos após diversas pesquisas que apontavam que surdos filhos de surdos tinham um maior aproveitamento escolar que surdos filhos de ouvintes. Para seus adeptos, a comunicação com a criança surda deveria ocorrer de diferentes formas, cabendo à criança a escolha daquela que ela se adaptava melhor. Para isso, seus interlocutores lançavam mão de sinais retirados da língua de sinais, de gestos, da datilologia e de expressões faciais, que eram acompanhados da linguagem oral, que pressupunha-se ser "ouvida" por meio de aparelhos de amplificação sonora individual. "A ideia era usar qualquer forma que funcionasse para transmitir vocabulário entre o falante e a criança surda. $\mathrm{O}$ importante era fornecer uma comunicação fácil, livre, de dois caminhos entre a criança Surda e o seu ambiente mais próximo" (MOURA; LODI; HARRISON, 2005, p. 296). Na prática, esta forma de comunicação ficou conhecida como comunicação bimodal ou bimodalismo, por utilizar tanto uma forma de interação oral quanto gestual.

Ao discutir a comunicação bimodal adotada nas escolas de surdos do Brasil, Moura (2000) ressaltou uma contradição entre o previsto teoricamente e a prática realizada. Para a autora, nas escolas que se diziam bimodais,

a ênfase é colocada na oralidade e o papel da escola permanece mais voltado para a oralização do que para o conteúdo programático. $\mathrm{O}$ Surdo ainda é visto como um caso médico e os velhos modelos de ensino de leitura e escrita, utilizados quando estas escolas eram oralistas, continuam a ser aplicados, sem nenhuma mudança ou visão de que, se a forma de trabalho mudou, assim também deve ser feito com as abordagens de letramento das crianças (p.63). 
Outra autora que se posicionou de forma contraria tanto à perspectiva oralista quanto à comunicação bimodal, foi Ferreira Brito (1989). Para ela, o oralismo rejeitava a língua de sinais e, portanto, a identidade cultural dos surdos, sendo, com isso, o responsável pelo fracasso educacional enfrentados por esse grupo social. No que se refere à comunicação bimodal, entendia-a como "um oralismo disfarçado com roupas de bilinguismo" (p.91), ao tentar usar simultaneamente duas línguas, a de sinais e a oral. Para a autora, nesta prática, novamente a língua de sinais foi desconsiderada servindo, apenas, como uma "forma de apoio à língua oral” (p.91).

Apesar das críticas realizadas, a comunicação bimodal gradativamente passou a ser utilizada em muitas escolas e classes especiais para deficientes auditivos no Brasil (incluindo São Paulo), embora ainda existissem escolas de cunho unicamente oralista.

$\mathrm{O}$ segundo movimento dizia respeito à Feneida. Como dito anteriormente neste texto, esta Federação era composta unicamente por ouvintes, razão pela qual os surdos não se sentiam por ela representados. Nesse contexto de lutas e reivindicações para ocupar espaços de representação, os surdos passaram a exercer forte pressão para que aquela instituição se abrisse também para eles. Instaurou-se assim um sério conflito relacional entre ouvintes e surdos, na medida em que os surdos se indignavam por não serem aceitos como representantes daquela instituição. Por este motivo, organizaram-se, em uma nova ação coletiva, a fim de assumirem a Feneida, mostrando, desse modo, que eram perfeitamente capazes de gerir assuntos que eram de seu próprio interesse.

Esta ação foi pensada a partir de distintas estratégias a fim de ser possível "mobilizar e articular associações de surdos de diferentes localidades do país" (BRITO, 2013, p. 109), como forma de criar uma rede de relações capaz de fortalecer o movimento. A partir de uma comissão formada por representantes das Associações de Surdos do Rio de Janeiro, Minas Gerais, São Paulo e Paraná, realizaram, pela primeira vez, uma passeata na cidade do Rio Janeiro, em 1984, como forma de tornar sua luta visível para a sociedade.

No que se refere à CBDS, surdos de diferentes associações brasileiras, entre elas a ASMSP, que lutavam pelo reconhecimento da língua de sinais e contra a Feneida, passaram a organizar nova ação coletiva com o objetivo de obter respostas quanto à demora do Conselho Nacional de Desporto (CND) em autorizar a fundação da CBDS. A deliberação favorável e a publicação da decisão no Diário Oficial da União ocorreram em 1984 (ABREU, 2016f). 
De acordo com Abreu (2016f), após a aprovação da Confederação, foi realizada uma segunda assembleia com a presença de representantes de todas as associações envolvidas, na qual foi votado o estatuto oficial da CBDS e foram escolhidos os membros que comporiam sua diretoria: Mario Pimentel como presidente; Antônio Campos de Abreu seu vice-presidente, Ana Regina e Souza Campello, diretora jurídica; Fernando Valverde, diretor esportivo; Sílvia Sabanovaite, secretária; e Neivaldo Zovico, tesoureiro.

Para Mario Pimentel, segundo Abreu (2016f), a criação da CBDS foi possível graças ao trabalho de todos como equipe. Os surdos se mantiveram solidários a fim de ser possível a fundação e o desenvolvimento da instituição e, no decorrer deste processo, mostravam-se cada vez mais unidos aproveitando as diferentes oportunidades que surgiam para aprender e compartilhar experiências, independente das diferenças educacionais e geracionais. Pode-se dizer, portanto, que os anos que se passaram até a fundação da CBDS, constituiu-se em uma ação coletiva que determinou o fortalecimento de uma identidade coletiva surda que influenciou, de forma significativa, as relações sociais na vida cotidiana da Confederação.

O processo de fundação da CBDS pode ser entendido ainda a partir de um intenso esforço intergeracional, conforme compreendido por Mannheim e discutido por Weller (2010), ou seja, no decorrer dos anos, foi possível o estabelecimento de vínculos que possibilitaram que o grupo dos surdos de diferentes gerações exercesse uma prática coletiva, dinâmica e interativa, por meio da qual cada um pode assumiu posições específicas no interior do grupo construindo e compartilhando experiências.

Torna-se possível perceber assim, que embora a ASMSP tivesse como foco principal atividades esportivas, ela teve um papel fundamental na formação de outros atores sociais, na medida em que apoiava e colaborava com outras ações, partilhando sua experiência e possibilitando a aprendizagem de todos que com ela se envolviam. Compreende-se assim, em consonância com Melucci (1989, 2001), que as ações coletivas não possuem um único objetivo ao longo do tempo e nem são mantidas por um único ator social; elas se fragmentam, se espalham, se recriam com o acúmulo histórico de experiências e conhecimentos. Assim, a partir da formação de uma identidade coletiva, novos atores sociais passaram a se envolver e a participar de novas ações em novos contextos. Destaca-se, segundo Abreu (2016f) e conforme a entrevista com Mario Pimentel, a saída de alguns membros da CBDS no decorrer dos anos para participação 
em outras ações, como por exemplo, a de Ana Regina e Souza Campello para tornar-se a primeira presidente surda da Feneis (RJ), a de Antônio Campos de Abreu para atuar na Associação de Surdos de Minas Gerais, e na década seguinte, a de Neivaldo Zovico, Silvia Sabanovaite e de Maria Cristina Machado, para a direção da Feneis - Regional São Paulo.

Pode-se dizer, portanto, que a fundação da ASMSP pode ser comparada com uma árvore, que cresceu, se fortaleceu e amadureceu; seus galhos geraram flores - a fundação de outras associações e da CBDS - e frutos - novos movimentos sociais, que irão se concretizar posteriormente: a fundação da Feneis e o reconhecimento da língua de sinais e da importância da educação bilíngue para surdos.

Na segunda metade de 1980, o confronto civil contra os sistemas sociais no país se intensificou em direção as "Eleições Diretas Já". Esta pressão social fez com que o Congresso Nacional votasse a favor da eleição de um presidente civil, mesmo ainda de forma indireta - Tancredo Neves - fato que permitiu que a democracia começasse a voltar a se instalar no Brasil (FAUSTO, 2009). No entanto, Tancredo veio a falecer antes de tomar posse, deixando, como presidente do Brasil, seu vice José Sarney. No entanto, os movimentos sociais não cessaram e novas e velhas reivindicações relativas à melhoria da vida da sociedade brasileira passaram a ser feitas.

Destaca-se, frente aos objetivos desta dissertação, o movimento dos surdos a fim de tornar possível a criação de uma Federação Nacional de Surdos em substituição à existente Feneida. De acordo com Brito (2013), em 1986, foi realizada uma nova assembleia no interior do Ines, com o objetivo de reestruturar a Feneida a partir da eleição de novas pessoas para assumirem os cargos de diretoria. Um dos líderes da Comissão de Defesa dos Direitos das Pessoas Surdas, Ana Regina e Souza Campello, pleiteou a presidência da instituição, mas naquele momento, os surdos ainda sofriam preconceitos e eram olhados com desconfiança pelos ouvintes, como pode ser observado na entrevista concedida por Ana Regina ao pesquisador Fabio Brito (2013):

Naquela época, em 1985, me disseram que não precisava criar uma associação em nível nacional, por não contar com recursos para pagar o registro no cartório do estatuto e da ata da diretoria, que eram caros. Avisaram-me que, no Ines, tinha a Feneida. Procurei a presidenta Lídia Rosas e apresentei meu interesse em candidatar a Feneida. Logo, ela riu a minha cara, dizendo que, como pessoa Surda, era inviável a minha candidatura. Eu, como pessoa esperta e resiliente, indaguei: Por que não experimentarmos a eleição para ver a possibilidade de ganhar ou perder 
a eleição? [...] A Feneida estava atravessando uma crise. Os membros da diretoria estavam desistindo de continuar trabalhando na gestão deles. Durante esse tempo, a Feneida publicou o edital de convocação da Assembleia Geral da Feneida e no mês de maio de 1986, no auditório do Ines, nós duas apresentamos nossas propostas como candidatas. $\mathrm{E}$ como só tinha três associações filiadas que quitaram mensalidades, a candidata Lídia Rosa recebeu um voto e eu recebi outro voto, restando apenas um voto. Era de uma associação filiada do Paraná, cuja presidenta é mãe de uma Surda (atualmente psicóloga e formada em Letras-Libras). Ela estava indecisa na questão do voto. Falou que conhecia o trabalho da Lídia Rosa, mas que a Feneida estava desacreditada e, como tem uma filha Surda (que era pequena naquela época), me via como modelo para a filha dela e depositou em mim a esperança na causa das pessoas Surdas. Ela me deu um voto e acabei ganhando dois votos contra um. A emoção foi grande. Percebi que persistindo tudo é possível, mesmo no impossível (p. 112-113).

No ano seguinte, ainda segundo Brito (2013), a então presidente Ana Regina Campello convocou nova assembleia para que o estatuto da Feneida fosse alterado; estiveram presentes dezessete representantes de diferentes associações de surdos. Nesta foi aprovado o novo nome da instituição: Federação Nacional de Educação e Integração dos Surdos (Feneis). Neste mesmo período, as comunidades surdas passaram a se relacionar com pesquisadores de Universidades públicas e privadas e, nesta parceria, começaram a estudar e a compreender que a língua de sinais era fundamental para a educação dos surdos.

Uma das pesquisadoras, Lucinda Ferreira Brito, em 1986, foi convidada a participar da Comissão Paulista para a Defesa dos Direitos dos Surdos (Copadis), que tinha como objetivo discutir os direitos e deveres dos surdos, elaborar ações para difundir e reconhecer a língua de sinais, conhecida naquele contexto sócio-histórico por Língua de Sinais das Cidades Brasileiras (LSCB), e sua aceitação e utilização na e para a educação dos surdos. Defendia-se que apenas por intermédio desta língua os surdos poderiam manifestar sua cultura.

Ainda na capital paulista, em 1987, teve início outra ação coletiva envolvendo pais, professores, Sociedades de Amigos de Bairro e a ASMSP para reivindicar, junto à Câmara Municipal, a criação de escolas especiais para surdos em cada região da cidade. Acreditava-se na necessidade destes espaços escolares para o desenvolvimento e aprendizagem escolar dos alunos (ainda considerados deficientes auditivos). O pedido desta ação foi aprovado pela Câmara Municipal, por meio da Lei n ${ }^{0} 10.567$, em 4 de julho 
de 1988, e foram criadas quatro Escolas Municipais de Educação Infantil e de $1^{\mathrm{o}}$ grau para Deficientes Auditivos (Emeda): Anne Sullivan, localizada na zona Sul da cidade de São Paulo; Neusa Basseto, na zona Leste; Professora Vera Lúcia Aparecida Ribeiro, na zona Oeste; e Madre Lucie Bray, na zona Norte (SÃO PAULO, 2005).

Por volta do ano de 1988, de acordo com Brito (2013), Lucinda Ferreira Brito foi convidada para participar das reuniões da Comissão de Educação, Cultura e Desporto da Assembleia Nacional Constituinte (ANC). Nesta, a pesquisadora sugeriu a inclusão, no texto da Constituição Federal em discussão, da língua brasileira de sinais e das línguas indígenas, como línguas autóctones, nos ambientes educacionais e, portanto, da educação bilíngue para surdos e para as comunidades indígenas respectivamente. Entretanto, em função da pouca difusão da língua de sinais e dos poucos conhecimentos sobre as comunidades surdas pela sociedade brasileira, a ANC não incluiu a língua brasileira de sinais no texto de nossa Carta Magna. Porém, as lutas dos surdos pelo reconhecimento da Libras não cessaram; elas, na verdade, estavam apenas no começo e se intensificaram nas próximas décadas (BRITO, 2013).

\section{5 A mudança de nome da ASMSP, sua parceria com a Feneis-SP e a luta dos surdos pelo reconhecimento da Libras}

No final da década de 1980, foi aprovada a nova Constituição da República Federativa do Brasil e, nela, depositada a esperança de que o país retomaria a democracia como forma de governo, retornando, aos cidadãos brasileiros, os direitos retirados nos anos da ditadura militar. No ano de 1990, houve a primeira eleição direta para presidente pós período militar, reivindicação esta que era pauta da sociedade brasileira desde meados da década anterior. Como presidente, foi eleito Fernando Collor de Mello, que sofreu impeachment dois anos depois.

Segundo Marcílio (2005), neste período, o mundo começava a vivenciar o fenômeno da globalização que determinava, além da "interdependência econômica" (p. 338) entre os países, o aumento no número de empresas multinacionais naqueles tidos como "em desenvolvimento". No entanto, o novo governo não trouxe mudanças sociais significativas para a população brasileira, que ainda sofria com os problemas herdados dos governos anteriores e que, por isso, poderiam ser considerados históricos no país. 
A desigualdade de oportunidades, a ausência de instituições do Estado confiáveis e abertas aos cidadãos, a corrupção, o clientelismo são males arraigados no Brasil. Certamente esses males não seriam curados da noite para o dia, mas poderiam começar a ser enfrentados no momento crucial da transição (FAUSTO, 2009, p.290).

O país mergulhava em um momento de alta inflação, de privatização de muitas instituições estatais, aumento da dívida externa e dos juros bancários. A partir de pesquisas realizadas naquele período, Marcilio (2005) descreveu o Brasil como um país pobre e injusto, no qual " $34 \%$ de seus habitantes [estariam] abaixo da linha de pobreza" (p. 339). O reflexo da desigualdade social era também sentido na educação brasileira.

Aos 21 anos de idade, os 10\% mais ricos frequentavam, em média, dez anos de escola, já os $40 \%$ mais pobres dessa faixa etária estudaram apenas por quatro anos, segundo estudo de BID [Banco Interamericano de Desenvolvimento]. A diferença é uma das resultantes de altas taxas de evasão escolar nas classes mais baixas, onde poucos completam o ensino fundamental (MARCILIO, 2005, p. 340).

Tornava-se então necessário o desenvolvimento de ações no âmbito da educação brasileira, que foram consideradas prioritárias: "a erradicação do analfabetismo, a universalização do atendimento escolar de base, a melhoria da qualidade do ensino, a formação para o trabalho, a formação humanística, científica e tecnológica do país" (MARCILIO, 2005, p. 346). O alto índice de analfabetismo ainda presente no país determinou que o Brasil fosse

indicado para compor o grupo de países priorizados pela ajuda internacional, grupo esse que passou a se reunir sob denominação de 'Cúpula dos Nove' (...) e que são: Bangladesh, Brasil, China, Egito, Índia, Indonésia, México, Nigéria e Paquistão"(ARELARO, 2002 apud MARCÍLIO, 2005, p. 346).

O Banco Mundial passou a intervir, encorajando "seus clientes" a realizarem maiores investimentos na área educacional, considerada responsável pela aceleração do desenvolvimento nacional e pela maior equidade social; nesse contexto, o Brasil tornouse signatário da Declaração Mundial sobre Educação para Todos, documento resultante da Conferência Mundial sobre Educação para Todos, realizada em Jomtien, Tailândia, em 1990, promovida pelo Programa de Desenvolvimento das Nações Unidas (PNUD), 
pela Organização das Nações Unidas para a Educação, a Ciência e a Cultura (Unesco), pelo Fundo das Nações Unidas para a Infância (Unicef) e pelo Banco Mundial.

Sobre esta Conferência, Lodi (2014) salientou que por seu intermédio foi possível o estabelecimento de um amplo diálogo internacional sobre o lugar que a educação ocupava nas políticas de desenvolvimento humano, ao se considerar que grande parte da população ainda era excluída deste direito, previsto na Declaração dos Direitos Humanos de 1948. Nesse sentido, naquela Declaração, foram elaboradas proposta a fim de que fosse assegurado, a todo cidadão, o direito à educação, base sobre a qual foram estabelecidas diretrizes para se pensar a construção do ideário da "Escola para Todos".

No entanto, a realidade vivida no país ainda estava distante das propostas internacionais. No que se refere à educação pública no estado e no município de São Paulo, o grande desafio era ainda o de oferecer um maior número de escolas à população. Entretanto, segundo Marcílio (2005), nenhum prefeito que assumiu o cargo na capital paulista, na década de 1990, respeitou a Lei Orgânica que determinava que 30\% da verba do município deveria ser destinado à educação, fato que só piorava a situação educacional de grande parte da população, em especial daqueles menos favorecidos sócio e economicamente.

No que diz respeito à educação de surdos, a prefeitura de São Paulo mantinha as cinco Escolas Municipais da Educação de Deficientes Auditivos (Emedas) comentadas anteriormente e, nestas, intensificava-se o uso da comunicação bimodal em substituição à perspectiva oralista. No entanto, fora das salas de aulas, os alunos menores, os jovens e os adultos surdos, em decorrência dos pontos de encontro em espaços ao redor das escolas, usavam livremente a Libras, em uma interação na qual as diferenças sociais e educacionais não importavam.

A luta dos surdos pelo reconhecimento da Libras se intensificou nos primeiros anos da década de 1990, influenciada, principalmente, pelas novas parcerias que eles estabeleciam com pesquisadores de algumas universidades. A importância da luta contínua dos surdos pelo reconhecimento da língua de sinais e sua importância para a compreensão e estudos sobre a cultura surda foi tema de um primeiro documento, assinado pela pesquisadora Tanya Amara Felipe, intitulado "As comunidades surdas reivindicam seus direitos linguísticos”, que foi publicado pela Feneis - RJ, em 1993. Neste mesmo documento foi também proposta a mudança de denominação da língua: de 
Língua dos Sinais das Cidades Brasileiras (LSCB), como vinha sendo chamada na esfera acadêmica, para Língua Brasileira de Sinais (Libras).

Com a maior circulação social da Libras em diferentes espaços sociais, mas em especial nas escolas (ainda que informalmente), e das lutas pelo reconhecimento da Libras e pela aceitação desta língua nos espaços escolares, a educação começou também a ser tema de discussão entre os membros da ASMSP. Este fato pode ser observado na Ata nºb, em 1992, na qual se assume a importância de haver maior divulgação social da Libras e, como decorrência, a ASMSP promoveu, em colaboração com a Feneis - RJ, o primeiro curso de "Linguagem de Sinais".

No ano seguinte, em 1993, foi realizado na cidade de São Paulo, o Simpósio Internacional de Língua de Sinais e Educação do Surdo, promovido pela Sociedade Brasileira de Neuropsicologia, primeiro evento no estado que teve assistência de surdos e contou com intérpretes de língua de sinais.

\begin{abstract}
A motivação maior para a realização deste Simpósio foi a necessidade de se discutir e trazer ao conhecimento de surdos, pais de surdos, professores, pedagogos, fonoaudiólogos, psicólogos e médicos, enfim todos os profissionais, ou não, que estão preocupados ou vivem os problemas da educação do surdo, as mais recentes pesquisas nesta difícil área. (...) Este problema [a prática de educação oralista] não se circunscreve apenas à realidade brasileira, mas à realidade educacional do surdo em todo o mundo. Baseados nestes fatos, muitos pesquisadores vêm desenvolvendo trabalhos que apontam o bilinguismo com uma proposta educacional que, além de dar condições de aprendizado para o indivíduo surdo, os respeitaria no seu contexto individual e cultural ${ }^{27}$ (MOURA, 1993, s/p.).
\end{abstract}

O ano de 1994, no contexto mundial, foi marcado pela realização da Conferência Mundial sobre Necessidades Educativas Especiais: acesso e qualidade, realizada em Salamanca, Espanha, em 1994, promovida pela Unesco e pelo Ministério de Educação e Ciências da Espanha. Nesta foram proclamados a Declaração de Salamanca e o Marco

\footnotetext{
${ }^{27}$ De acordo com relato da mãe da pesquisadora, ela e outros pais de surdos, estudantes da Escola Municipal de Educação de Deficientes Auditivos Vera Lucia Aparecida Ribeiro, foram convidados para assistir ao evento. As palestras e conferências ali realizadas foram de grande impacto para ela, pois foi a primeira vez que teve contato com professores e pesquisadores surdos, também palestrantes, que discutiam a importância da língua de sinais nas escolas de surdos. Nunca tinha lhe ocorrido a possibilidade de surdos se formarem professores. Pela primeira vez, via para sua filha surda e para os outros alunos da escola, possibilidades profissionais futuras, possíveis pela língua de sinais; oportunidades que independia da falta da audição e da fala.
} 
de Ações para as Necessidades Educativas Especiais, nos quais o Brasil também figurou como signatário. Estes documentos defendiam "o direito de todas as crianças a processos educacionais que respeitem suas 'características, interesses, capacidades e necessidades de aprendizagem ${ }^{28}$ "' (UNESCO, 1994, p.viii apud LODI, 2014, p. 269). E no que diz respeito aos alunos com necessidades educacionais especiais, este conceito passou a ser ampliado, englobando "todas as crianças e jovens cujas necessidades derivam de sua capacidade ou dificuldade de aprendizagem (UNESCO, 1994, p.6) de forma permanente ou transitória ${ }^{29 "}$ (LODI, 2014, p.270).

Em consonância com a Declaração de Jomtien, a de Salamanca também defendia a Escola para Todos, espaços educacionais que deveriam ser organizados para receber "crianças deficientes e crianças bem dotadas, crianças que vivem na rua e que trabalham, crianças de populações remotas ou nômades, crianças de minorias linguísticas, étnicas ou culturais e crianças de outros grupos ou zonas desfavorecidas ou marginalizadas ${ }^{30 "}$ (UNESCO, 1994 apud LODI, 2014, p.269). No entanto, conforme ressaltado por Lodi (2014), exceção foi feita no caso de alunos surdos e surdo-cegos, por reconhecer o direito destes grupos à uma educação pensada a partir da língua de sinais. Nesse sentido, orienta que a educação destes alunos seja realizada em escolas especiais ou em classes especiais no interior das escolas regulares.

Embora esta orientação tenha tido pouco (ou nenhum) reflexo no Brasil, não se pode negar que o direcionamento dado à educação de surdos em âmbito mundial ia ao encontro dos movimentos surdos brasileiros que defendiam a Libras como fundamental para sua constituição identitária e cultural e para os processos educacionais de seus pares; clamava-se, portanto, pela implantação da educação bilíngue para surdos, por meio da qual fosse garantido a presença e participação de

professores surdos e/ou ouvintes que dominem a língua de sinais em todos os processos escolares e em todos os níveis de escolarização; que os currícula contemplem e fortaleçam a cultura surda; e que o ensino da escrita respeite a visualidade constitutiva da língua de sinais e da

\footnotetext{
${ }^{28}$ No original: el derecho de todos los niños a procesos educativos que respeten sus "características, intereses, capacidades y necesidades de aprendizaje" ((UNESCO, 1994, p.viii apud LODI, 2014, p. 269).

${ }^{29}$ No original: "a todos los niños y jóvenes cuyas necesidades se derivan de su capacidad o sus dificultades de aprendizaje" (UNESCO, 1994, p. 6), de forma permanente o transitoria (LODI, 2014, p.270).

${ }^{30}$ No original: niños discapacitados y niños bien dotados, niños que viven en la calle y que trabajan, niños de poblaciones remotas o nómadas, niños de minorías lingüísticas, étnicas o culturales y niños de otros grupos o zonas desfavorecidos o marginados (Unesco, 1994 apud LODI, 2014, p.269).
} 
escrita ao mesmo tempo em que se considera que a escrita é uma segunda língua para os surdos (LODI, 2014, p. 263-264) ${ }^{31}$.

No entanto, de forma contrária às solicitações das comunidades surdas, que já recebiam apoio de vários pesquisadores, o compromisso do governo brasileiro em relação às Declarações de Jomtien e de Salamanca centrou-se, unicamente, na necessidade de se colocar em prática a educação inclusiva, compreendida de forma distinta daquela presente nos documentos oficiais das Conferências.

Segundo Mendes (2006), o princípio da inclusão, no contexto mundial, era defendido como uma possibilidade de se pôr em prática na área educacional, o movimento de inclusão social, entendido como

a construção de um processo bilateral no qual as pessoas excluídas e a sociedade buscam, em parceria, efetivar a equiparação de oportunidades para todos, construindo uma sociedade democrática na qual todos conquistariam sua cidadania, na qual a diversidade seria respeitada e haveria aceitação e reconhecimento político das diferenças (p. 395).

No entanto, conforme discutiu a autora, as próprias políticas implantadas desde 1970 pela Secretaria de Educação Especial do Ministério da Educação (Seesp/MEC), responsável por traçar as diretrizes e orientar as práticas de educação especial no Brasil, tornavam-se entraves para a implantação da política de inclusão escolar em nosso país: nos anos 1970, quando foi criada, esta Secretaria, de forma explícita, incentivava a iniciativa privada e as organizações não-governamentais a assumirem a responsabilidade pela educação dos alunos com deficiência; este sistema paralelo de educação, acabou sendo reforçado anos mais tarde pelos estados, que se viam incentivados a implantar classes especiais nas escolas públicas a partir do investimento realizado pelo governo federal na formação de professores especializados por área de deficiência. Nesse sentido, apesar dos compromissos assumidos com os órgãos internacionais, a política de educação inclusiva não se tornou realidade nos anos 1990.

\footnotetext{
${ }^{31}$ No original: "profesores sordos y/u oyentes dominen la lengua de señas para todos los procesos escolares y en todos los niveles de escolarización; de que los currículos contemplen y fortalezcan la cultura sorda; y de que la enseñanza de la escritura respete la visualidad constitutiva de la lengua de señas y de la escritura, al tiempo que tenga en cuenta que la escritura se realiza en uma segunda lengua para los sordos" (LODI, 2014, p.263-264).
} 
No ano de 1996 foi publicada, no dia 20 de dezembro, a nova Lei de Diretrizes e Bases da Educação Nacional (Lei n ${ }^{0}$ 9.394), que passou a compreender a educação como um processo formativo que se desenvolve "na vida familiar, na convivência humana, no trabalho, nas instituições de ensino e de pesquisa, nos movimentos sociais e organizações da sociedade civil e nas manifestações culturais" (BRASIL, 1996, Artigo $1^{\circ}$ ). No que diz respeito à educação escolar pública, tornou-se dever do Estado assegurar "ensino fundamental, obrigatório e gratuito, inclusive para os que a ele não tiveram acesso na idade própria" (BRASIL, 1996, Artigo 4º Inciso I), “progressiva extensão da obrigatoriedade e gratuidade ao ensino médio" (Idem, Inciso II) e "atendimento gratuito em creches e pré-escolas às crianças de zero a seis anos de idade" (Idem, Inciso IV). No que diz respeito aos alunos com necessidades especiais, a eles foi garantido, conforme consta na Constituição de 1988, atendimento educacional especializado, havendo preferência de que este fosse realizado na rede regular de ensino (Idem, Inciso III).

Nesta Lei, pela primeira vez na história, foi dedicado um capítulo à educação especial, que passou a ser entendida como uma modalidade de educação escolar. Nesse sentido, cabia aos sistemas de ensino assegurar, entre outros aspectos, aos alunos: “currículos, métodos, técnicas, recursos educativos e organização específicos" (BRASIL, 1996, Artigo 59 , Inciso I); “terminalidade específica para aqueles que não puderem atingir o nível exigido para a conclusão do ensino fundamental, em virtude de suas deficiências" (Idem, Inciso II); "professores com especialização adequada em nível médio ou superior, para atendimento especializado, bem como professores do ensino regular capacitados para a integração desses educandos nas classes comuns" (Idem, Inciso III); “educação especial para o trabalho, visando a sua efetiva integração na vida em sociedade, inclusive condições adequadas para os que não revelarem capacidade de inserção no trabalho competitivo" (Idem, Inciso IV). Observa-se, no entanto, na continuidade do texto, que, ao mesmo tempo em que se privilegia a educação regular para a escolarização dos alunos da educação especial prevendo-se, inclusive, a ampliação do atendimento, o Artigo 60 da LDB/96 dispõe sobre a possibilidade de ele ser realizado por instituições privadas sem fins lucrativos.

Estas disposições relativas à educação especial diziam respeito também aos alunos surdos, e embora a LDB tenha tido como base a Declaração de Salamanca para a redação da forma pela qual os alunos passariam a ser denominados - alunos com necessidades 
especiais - as orientações previstas pela Declaração no que diz respeito aos surdos foi, pela primeira vez, ignorada em um documento legal.

Neste mesmo ano, no entanto, intensificaram-se, também em âmbito oficial federal, discussões que envolviam a legalização da Libras e seu reconhecimento como língua, bem como o seu uso para os processos educacionais de surdos. Em função do Projeto de Lei $\mathrm{n}^{\mathrm{o}} 131 / 96$, em tramitação no Senado Federal, proposto pela senadora Benedita da Silva, a Coordenadoria Nacional para Integração da Pessoa com Deficiência (Corde) promoveu a Câmara Técnica "O Surdo e a Língua de Sinais”, que foi composta por

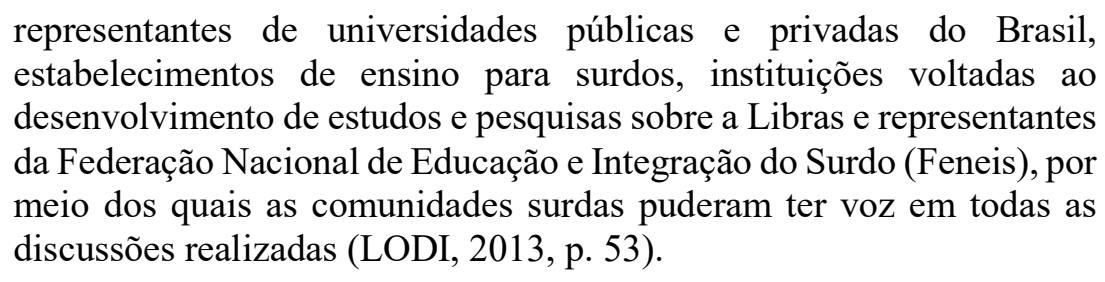

Apesar deste trabalho, o Projeto de Lei tramitou ainda por seis anos no Senado, tornando-se a base para a redação da Lei $n^{\circ} 10.436 / 02$ e, posteriormente, para a do Decreto Federal $n^{0} 5.626 / 05$ que a regulamenta.

Neste contexto de intensos movimentos dos surdos para o reconhecimento da Libras e para a transformação das escolas especiais em escolas bilíngue para surdos, em 1997, o estatuto da ASMSP foi reformulado e nele nova denominação foi dada a este ator social de grande importância para os surdos brasileiros: Associação de Surdos de São Paulo (ASSP). Ela ainda se torna de caráter beneficente, cultural, educativa, desportiva, recreativa, social, aspectos que podem ser observados nas finalidades da ASSP que passaram a constar de seu novo estatuto:

a- A integração das pessoas portadoras de surdez, prestar assistência social e cultural aos seus associados;

b- Estabelecer convênios, realizar e participar de eventos, em conjunto com entidades congêneres, e outras;

c- Atividades sociais como promoção de festas e reuniões, diversões, excursões, que visem uma maior aproximação entre seus associados e familiares;

d- Atividades esportivas, através da realização de torneios, campeonatos entre associados e competições em outras associações congêneres, no âmbito nacional e internacional; 
e- Atividades culturais, tais como: incentivar organização de biblioteca, promoção de cursos de iniciação e aperfeiçoamento, conferencias e palestras, que objetivem a divulgação e uma maior difusão da associação no meio social do município e do Estado;

f- Patrocinar e promover o intercâmbio social e cultural com entidades no Brasil e no exterior;

g- Reivindicar e promover, em todas as esferas do poder público, o que for necessário para a inserção das pessoas portadoras de surdez na sociedade;

h- Conscientizar a comunidade sobre as reais potencialidades e limitações dos surdos;

i- Promover a formação, informação e conscientização dos surdos, a fim de que eles se tornem efetivamente comprometidos e militantes da entidade, inclusive pelo uso da Língua Brasileira de Sinais - Libras. (ASSP, Caderno de Ata n 8 , p. 21)

Observa-se assim, neste novo estatuto, uma maior inserção e preocupação da ASSP com os diferentes aspectos que envolvem a vida dos surdos, comprometendo, a todos, com a instituição e com o uso da Libras.

Neste mesmo ano, a Feneis abriu uma diretoria regional na cidade de São Paulo, fato que acabou por aproximar as duas instituições, que se uniram à Feneis - RJ e às diferentes associações na liderança de diferentes ações dos surdos empreendidas em distintos estados brasileiros. A principal luta continuava a ser pressionar o governo para que ele reconhecesse a língua brasileira de sinais como a língua "falada" pelos surdos.

Na cidade de São Paulo, as antigas Emedas passaram a ser denominadas Escolas Municipais da Educação Especial (Emees), sem alteração significativa dos processos de escolarização dos surdos. Foi ainda criada a sexta escola para surdos, também na zona norte da capital - Escola Municipal da Educação Especial Professor Mario Pereira Bicudo.

A luta dos surdos pelo reconhecimento da Libras e pela educação bilíngue seguia sem êxito. Neste contexto, em 1999, foi realizado um dos eventos mais importantes para as comunidades surdas brasileiras: o V Congresso Latino-Americano de Educação Bilíngue para Surdos, organizado pelo Núcleo de Pesquisas em Políticas Educacionais para Surdos (Nuppes) da Universidade Federal do Rio Grande do Sul (UFRGS) e que contou com a parceria da Feneis. Este reconhecimento sobre a importância deste Congresso pode ser observado nos relatos de pessoas surdas e ouvintes, que relataram à Brito (2013), que o consideraram "peça fundamental da campanha pela oficialização da Libras" (p.192), fato que ocorreu aproximadamente um ano e meio depois. 
Este evento propiciou ainda que os surdos fossem protagonistas em discussões e debates sobre questões sociais e educacionais que os envolvia e, nos dias que o antecederam, as comunidades surdas, reunidas, elaboraram o documento A educação que nós surdos queremos ${ }^{32}$. Destaca-se, deste documento, o seguinte trecho, retirado da seção "Direitos Humanos":

1. Propor o reconhecimento da língua de sinais como língua da educação do Surdo em todas as escolas e classes especiais de surdos.

2. Assegurar a toda criança surda o direito de aprender línguas de sinais e também português e outras línguas.

(...)

6. Levar em conta o conhecimento da língua de sinais para a escolha dos professores de surdos. Entende-se como prova de conhecimento em língua de sinais: certificado especifico de curso reconhecido pelas Associações e Federações de Surdos, com aprovação posterior em banca constituída pela comunidade surda.

(...)

15. Em educação, assegurar ao surdo o direito de receber os mesmos conteúdos que os ouvintes, mas através de comunicação visual. Formas conhecidas, em comunicação visual importantes para o ensino do surdo são: línguas de sinais, língua portuguesa, e outras línguas no que tange à escrita, leitura e gramática.

(...)

22. Considerar que a integração/inclusão é prejudicial à cultura, à língua e à identidade surda.

23. Propor o fim da política de inclusão/integração, pois ela trata o surdo como deficiente e, por outro lado, leva ao fechamento de escolas de surdos e/ou ao abandono do processo educacional pelo aluno surdo. 24. Considerar que a integração da pessoa surda não passa pela inclusão do surdo em ensino regular, devendo o processo ser repensado.

Observa-se, por meio deste documento, uma maior articulação política dos surdos quanto à luta que estavam empreendendo há anos, além de uma oposição explícita à política educacional brasileira que, naquele momento, começava a se organizar a fim de empreender esforços no sentido de implantar a educação inclusiva no país.

Compreende-se, neste movimento, que, pela primeira vez, as ações dos surdos voltaram-se para o rompimento com os sistemas sociais hegemônicos, dando, à sua luta, visibilidade nacional; uma prática política que, pode-se dizer, nascia com a organização dos surdos para a fundação da ASSP, que esteve presente, de forma direta ou indireta, nas diversas outras ações ocorridas no país.

32 Disponível em: < http://docslide.com.br/documents/a-educacao-que-nos-surdos-queremos.html $>$. Acesso em 5 jun. 2017. 


\section{6 A continuidade da luta dos surdos paulistas pelo reconhecimento da Libras e pela defesa da Educação Bilíngue para Surdos}

Apesar de promover vários programas a fim de reverter os históricos problemas sociais existentes no país, o governo Fernando Henrique Cardoso ainda enfrentava, no início da década de 2000, alta taxa de desemprego, maior concentração de renda e riqueza nas mãos de uma pequena parcela da população, endividamento do setor público, grande carga tributária e a maior transferência do patrimônio público para a iniciativa privada em comparação a outros países (POCHANN, 2011). A educação brasileira, em especial na esfera pública, recebia investimentos tímidos, privilegiando-se àquela voltada aos alunos melhor favorecidos socioeconomicamente, realidade que levou o vice-presidente do Banco Interamericano de Desenvolvimento a afirmar que a "qualidade do ensino oferecido nas escolas públicas [no país] está[va] longe de atender às necessidades da população pobre, mantendo alta a taxa de evasão" (JORNAL DA USP, 1998, apud MARCÍLIO, 2005, p. 345).

Poucas mudanças também ocorriam na educação dos surdos nesta época, muito embora, paralelamente, as comunidades surdas brasileiras mantinham-se empenhadas em sua luta para o reconhecimento da Libras e para que esta língua fosse usada nos processos educacionais, ou seja, que fosse implantada no país a educação bilíngue em escolas e/ou classes bilíngues conforme descrita no documento "A educação que nós surdos queremos".

No que se refere à educação na cidade de São Paulo, a prefeitura ainda não cumpria o disposto na Lei Orgânica do Município, a fim de que medidas fossem tomadas visando a garantia de um maior acesso da população paulista às escolas públicas de Ensino Fundamental, bem como assegurar melhor qualidade no frágil ensino oferecido nestes espaços. Conforme discutiram Freitas e Silva (2002), as escolas públicas, especialmente, nas zonas Leste e Sul ainda mostravam deficiência no atendimento escolar, deixando parte das crianças que viviam nestas regiões excluídas das escolas.

A situação dos surdos na cidade de São Paulo não era diferente da oferecida no país, na medida em que a Libras não se fazia presente nas escolas especiais de surdos existentes no município. A ASSP e a Feneis, em parceria com as comunidades escolares, de surdos faziam pressão junto aos Poderes Públicos para que estas se transformassem 
em escolas bilíngues, assim como realizavam e participavam de eventos nos quais a necessidade de reconhecimento da Libras era frequentemente tematizada.

Conforme entrevista realizada para esta dissertação com Paulo Vieira, expresidente da ASSP entre os anos 2007 - 2010, Mario Júlio Pimentel Junior, que atuava como assessor da ASSP, participou de um evento voltado a pessoas com deficiência no Rio Grande do $\mathrm{Sul}^{33}$, no qual os surdos organizavam-se para pressionar os Poderes Públicos a fim de terem assegurados seus direitos linguísticos e, portanto, o acesso à educação e à informação por intermédio da Libras

Após esta vivência, Mario Pimentel Jr retornou à São Paulo, reuniu um grupo de voluntários (entre eles estava o entrevistado Paulo Vieira) com vistas a organizarem um evento nos mesmos moldes daquele realizado em Porto Alegre. A I Conferência dos Direitos e Cidadania dos Surdos do Estado de São Paulo (Condicisur) tornou-se realidade no ano de 2001 e foi promovida, segundo Paulo Vieira, pela ASSP e pela Feneis-SP; no entanto, conforme Brito (2013) e Cunha Jr (2017), além delas, a CBDS e a Cooperativa Padre Vicente de Paulo Penido Burnier (Copavi) foram também promotoras do evento. Segundo Brito (2013), o evento "teve um cunho essencialmente político, na medida em que o seu principal objetivo era discutir e elaborar propostas que atendessem as reivindicações trazidas pelos representantes das comunidades surdas da capital e do interior de São Paulo" (p. 200). Nele foram discutidas questões relacionadas a família, saúde, educação, cultura, comunicação, associações, trabalho, esporte, direitos e deveres (CUNHA JR, 2017) e teve ativa participação dos surdos.

Teve ainda como pauta principal a necessidade de reconhecimento da Libras pelas autoridades públicas de São Paulo. No que diz respeito à esta reivindicação, propostas de estratégias políticas que visavam pressionar os Poderes Públicos foram apresentadas e aceitas pelos participantes, pois era necessário "obter a aprovação de leis municipais e estaduais de reconhecimento da Libras, sem, com isso, perder o foco da reivindicação da oficialização dessa língua em âmbito nacional” (BRITO, 2013, p. 201).

\footnotetext{
${ }^{33}$ Paulo Vieira não se lembrava o nome exato desse evento.
} 
Figura 8: A Conferência dos Direitos e Cidadania dos Surdos do Estado de São Paulo

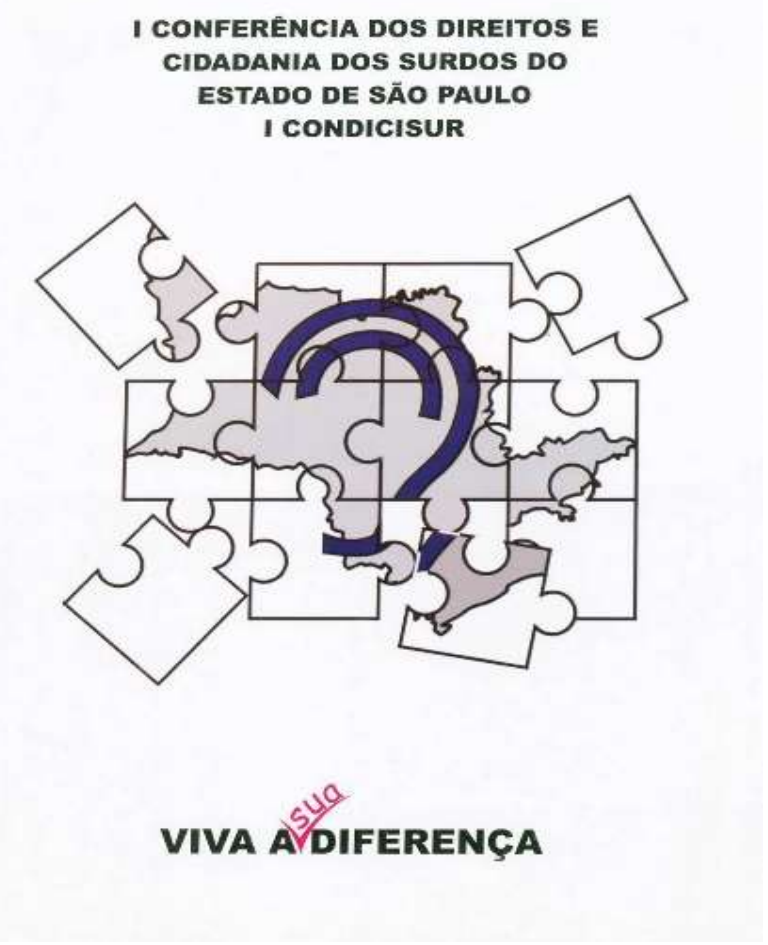

Fonte: Blog de I Condicisur ${ }^{34}$

A proposta reivindicatória tirada na Condicisur foi, enfim, aprovada: o reconhecimento da Libras no município de São Paulo ocorreu por meio da Lei Municipal $\mathrm{n}^{\mathrm{o}}$ 13.304, que foi sancionada pela prefeita Marta Suplicy e publicada no Diário Oficial no dia 21 de janeiro de $2002^{35}$. Consta nesta Lei, que a Libras deve ser reconhecida como a "língua de instrução e o meio de comunicação objetiva e de uso corrente da comunidade surda" (SÃO PAULO, 2002, Artigo $1^{\circ}$ ), por ser compreendida como "um meio de comunicação de natureza visual-motora, com estrutura gramatical própria oriunda de comunidades de pessoas surdas do Brasil, traduzindo-se como forma de expressão do surdo e sua língua natural” (Idem, Parágrafo Único).

Apesar do inegável ganho obtido por esta Lei para os surdos da cidade de São Paulo, observa-se que o reconhecimento da Libras se reduzia aos espaços escolares, na

\footnotetext{
${ }^{34}$ Disponível em $<$ http://icondicisur.blogspot.com.br/>. Acesso em 17.06.2017. cipio/janeiro/22/pag_0001_D5T8PE55QMGD1eFTPQSRSFPTK2J.pdf $>$. Acesso em 17 jun. 2017.
} 
medida em que o atendimento disposto na Lei previu capacitação profissional, unicamente, para aqueles servidores que trabalhavam "na rede pública municipal de ensino e nas instituições que atendem ao aluno surdo" (Idem, Artigo $5^{\circ}$ ). No entanto, a capacitação que a Lei fazia referência envolvia apenas a aprendizagem da Libras, que deveria ser "comprovada através de Certificado de Curso de Formação em LIBRAS, expedido por quaisquer entidades habilitadas em formação de Língua Brasileira de Sinais - LIBRAS" (Idem, Artigo 4º).

Desse modo, apesar do reconhecimento da Libras como língua de instrução, os princípios da educação bilíngue ainda estavam distantes de se tornarem realidade, pois a formação para a educação dos surdos deveria contemplar, além da língua, metodologias e práticas de ensino em Libras e a possibilidade de revisão curricular de forma a serem incluídos aspectos socioculturais e históricos das comunidades surdas.

No âmbito federal, três meses após a publicação da Lei Municipal em São Paulo, o presidente Fernando Henrique Cardoso, no dia 24 de abril de 2002, sancionou a Lei $n^{\circ}$ 10.436 (Lei da Libras), que reconheceu a língua brasileira de sinais como o "meio legal de comunicação e expressão" (BRASIL, 2002, Artigo $1^{\circ}$ ) das comunidades surdas brasileiras. Nesta Lei, da mesma forma como disposto na lei paulista, a Libras foi compreendida como uma "forma de comunicação e expressão, em que o sistema lingüístico de natureza visual-motora, com estrutura gramatical própria, constituem um sistema lingüístico de transmissão de idéias e fatos, oriundos de comunidades de pessoas surdas do Brasil” (Idem, Artigo 1, Parágrafo único).

Por meio desta lei, o Poder Público comprometeu-se em garantir "formas institucionalizadas de apoiar o uso e difusão da Língua Brasileira de Sinais - Libras como meio de comunicação objetiva e de utilização corrente das comunidades surdas do Brasil" (Idem, Artigo $2^{\circ}$ ), serviços de atendimento e tratamentos à saúde públicos adequados à legislação, ou seja, em Libras (Idem, Artigo $2^{\circ}$ ), assim como a inclusão do ensino da Libras nos cursos de Educação Especial, Fonoaudiologia e Magistério, devendo esta ser "parte integrante dos Parâmetros Curriculares Nacionais - PCNs" (Idem, Artigo 4). No entanto, no Parágrafo único deste último artigo, a fim de dar constitucionalidade a esta lei, foi disposto que a "Língua Brasileira de Sinais - Libras não poderá substituir a modalidade escrita da língua portuguesa". 
Apesar do inegável ganho desta legislação para as comunidades surdas brasileiras, em especial para que este reconhecimento ocorresse também pela sociedade em geral, era necessário que as associações de surdos, os líderes dos movimentos surdos, as escolas especiais, os professores, os alunos e seus familiares se mantivessem unidos, divulgando a lei e a Libras de forma que todos passassem a respeitar o direito linguístico das comunidades surdas e, portanto, o uso desta língua em todos os espaços sociais de atendimento à população, públicos e privados.

Compreende-se assim, à luz da perspectiva teórica de Melucci (2001), que foi neste contexto que a luta dos surdos ganhou visibilidade; foi um período no qual puderam experienciar maior solidariedade, compartilhar experiências e conhecimentos produzidos coletivamente no decorrer das diferentes ações empreendidas entre surdos de diferentes gerações (conforme compreendido por Mannheim, 1928 apud WELLER, 2010), visando, por meio desta nova ação, a ruptura com o sistema, sócio-historicamente constituído, que concebia e tratava os surdos como deficientes (da fala e da audição)

Um ano após a publicação da Lei da Libras, Luiz Inácio Lula da Silva, tomou posse como Presidente da República, com a responsabilidade de superar os problemas sociais, econômicos, políticos e educacionais que ainda persistiam no país. Nesse contexto, ele deu prosseguimento dos programas sociais criados pelo presidente anterior e criou novos a fim de reverter a desigualdade social, privilegiando segmentos sociais mais vulneráveis (OLIVEIRA, 2009), que foram tirados da linha pobreza. Um dos principais programas foi o conhecido Bolsa-Família (OLIVEIRA, 2009; POCHANN, 2011).

No que diz respeito aos programas sociais relacionados à educação, o governo Lula visou a expansão do acesso de crianças e jovens à educação básica e superior em instituições públicas municipais, estaduais e federais, investindo recursos do Fundo de Manutenção e Desenvolvimento da Educação Básica e de Valorização dos Profissionais da Educação, a fim de transformar a realidade educacional brasileira (OLIVEIRA, 2009).

No que se refere à educação dos surdos, no ano de 2005, foi sancionado o Decreto Federal $n^{\circ} 5.626$, que regulamentou a Lei da Libras e os Arts. $17^{\circ}$ e $18^{\circ}$ da Lei da Acessibilidade (Lei ${ }^{\circ}$ 10.098/00). Neste documento, foi assegurada a educação bilíngue para surdos e reconhecida a língua portuguesa como segunda língua na modalidade escrita para este grupo social; dispôs-se ainda sobre a formação do professor surdo e do instrutor 
de Libras (considerados como prioridade nos processos educacionais dos alunos surdos) e dos tradutores e intérpretes de Libras - Língua Portuguesa (TILSP).

No ano seguinte, o MEC promoveu, seguindo às disposições de Decreto, o primeiro curso de licenciatura em Letras - Libras, que esteve sob a responsabilidade da Universidade Federal de Santa Catarina (UFSC). O curso foi realizado à distância e envolveu nove polos, que contemplaram todas as regiões do país. O objetivo deste curso era o de formar professores de Libras para atuar na educação básica. No ano de 2008, este curso foi novamente oferecido, envolveu quinze polos, e, juntamente com ele, foi oferecido o curso de bacharelado em Letras - Libras voltado, especificamente, à formação do TILSP. Ainda a fim de atender a determinação do Decreto, no período de 2006 a 2010 , o MEC em parceria com o Instituto Nacional de Estudos e Pesquisas Educacionais Anísio Teixeira, criou o "Programa Nacional para a Certificação de Proficiência em Libras e para a Certificação de Proficiência em Tradução e Interpretação de Libras/Língua Portuguesa - Prolibras", programa que, nas sete edições realizadas, certificou 6.101 (seis mil, cento e um) profissionais (BRASIL, 2017).

No entanto, apesar desse contexto de ações afirmativas em prol das comunidades surdas brasileiras, três anos após a publicação do Decreto $n^{\circ} 5.626 / 05$, o próprio Governo Federal, por meio da então existente Secretaria de Educação Especial (Seesp/MEC) publicou a Política Nacional da Educação Especial na Perspectiva da Educação Inclusiva que passou a defender, de forma mais intensa, a inclusão dos surdos (assim como de todos os “deficientes”) na escola regular. Segundo o documento, esta ação visava superar as práticas discriminatórias historicamente construídas nos processos educacionais das pessoas com deficiência, práticas estas que acabaram por determinar a exclusão social deste alunado dentro e fora da escola (BRASIL, 2008)

Entretanto, segundo discutiu Lodi (2013), no que tange à educação dos surdos, as propostas e ações da Política acabaram por contradizer o disposto no Decreto $n^{0} 5.626 / 05$, pois, enquanto este último defendia e dava centralidade à Libras nos processos educacionais dos surdos, ao dispor sobre a importância da educação infantil e do anos iniciais do Ensino Fundamental estarem sob a responsabilidade de pedagogos bilíngues (logo serem desenvolvidos em Libras), a Política de Educação Especial orienta a inclusão dos surdos nas classes organizadas para alunos ouvintes por meio da presença de TISLP em todos os níveis de ensino. Outro aspecto discutido pela autora, diz respeito ao 
atendimento educacional especializado, previsto, pelo Decreto, para ser realizado por professores ou instrutores surdos. A Política, por sua vez, prevê este atendimento "tanto na modalidade oral e escrita quanto na língua de sinais" (BRASIL, 2008, p. 11), abrindo assim a possibilidade de a linguagem oral voltar a ser objeto de atenção no trabalho com os alunos surdos, na medida em que a formação prevista para o professor atuar na educação especial é bastante genérica no documento.

Após a publicação da Política, muitas escolas de surdos começaram a ser fechadas e os alunos transferidos para a escola regular. Este fato determinou novas ações coletivas por parte dos surdos brasileiros, que passaram a se mobilizar em defesa da educação bilíngue e, de forma mais marcada, contra a educação inclusiva.

Na cidade de São Paulo, segundo informou Paulo Vieira na entrevista concedida para esta pesquisa, a ASSP, em parceria com a Feneis, começou, então, a militar também em defesa da educação bilíngue, deixando um pouco de lado as questões relativas ao esporte. A fim de obter uma maior mobilização, o então presidente da ASSP foi às seis escolas municipais de educação especial, procurar apoio dos professores, funcionários, alunos e familiares de surdos e, juntos, organizaram uma manifestação pública, que ocorreu, no ano de 2009, na Avenida Paulista. Nesse movimento estavam ainda presentes as três escolas particulares existentes na grande São Paulo: o Instituto Santa Teresinha, o Centro de Educação para Surdos Rio Branco e a Escola de Educação Bilíngue para Surdos da Divisão de Educação e Reabilitação dos Distúrbios da Comunicação - Derdic (SILVA et al., 2009).

Segundo o relato dos autores,

Mais uma vez, uma mobilização política teria por palco esse famoso cartão postal da cidade de São Paulo. O número de participantes era relativamente tímido, se comparado a outras manifestações que costumam ocorrer no local, contudo, suficiente para tomar toda a calçada do Parque Trianon. Quem observava mais atentamente, percebia algumas particularidades na forma de comunicação das pessoas que se aglomeravam. Os manifestantes se comunicavam por meio de língua de sinais e, apesar de haver um carro de som no local, o foco de atenção estava voltado sobretudo para as pessoas que discursavam em língua de sinais, em pé, sobre as lixeiras de concreto da avenida, que serviam como palanques improvisados, a fim de tornar visíveis os seus sinais para os demais. Aquela concentração, aos poucos, demonstrava o seu objetivo em tomar parte da avenida: tratava-se de uma manifestação pelos direitos do que as pessoas denominam comunidade surda. Quando alguns surdos, representantes de 
associações, discursavam, o carro de som propagava a interpretação para o português realizada por um interprete. Inversamente, quando alguns ouvintes discursavam, o interprete presente ocupava o palanque improvisado interpretando o dito para Libras (SILVA et al., 2009, p. 12).

Fotografia 4: A mobilização de surdos na avenida Paulista

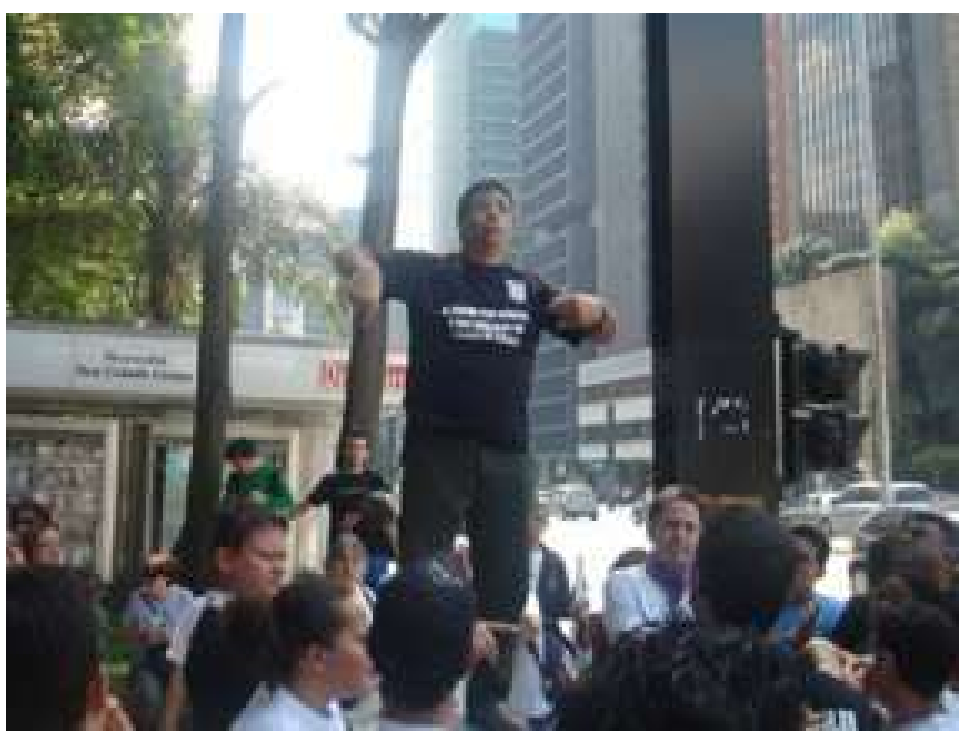

Fonte: SILVA el at, 2009, p.1.

Na foto: Em destaque, Neivaldo Zovico, Coordenador Nacional de Acessibilidade para Surdos da Feneis - SP, em um palanque improvisado. Logo abaixo, à esquerda, Paulo Vieira, presidente da ASSP.

\section{Fotografia 5: Uma das faixas usadas pelos manifestantes}

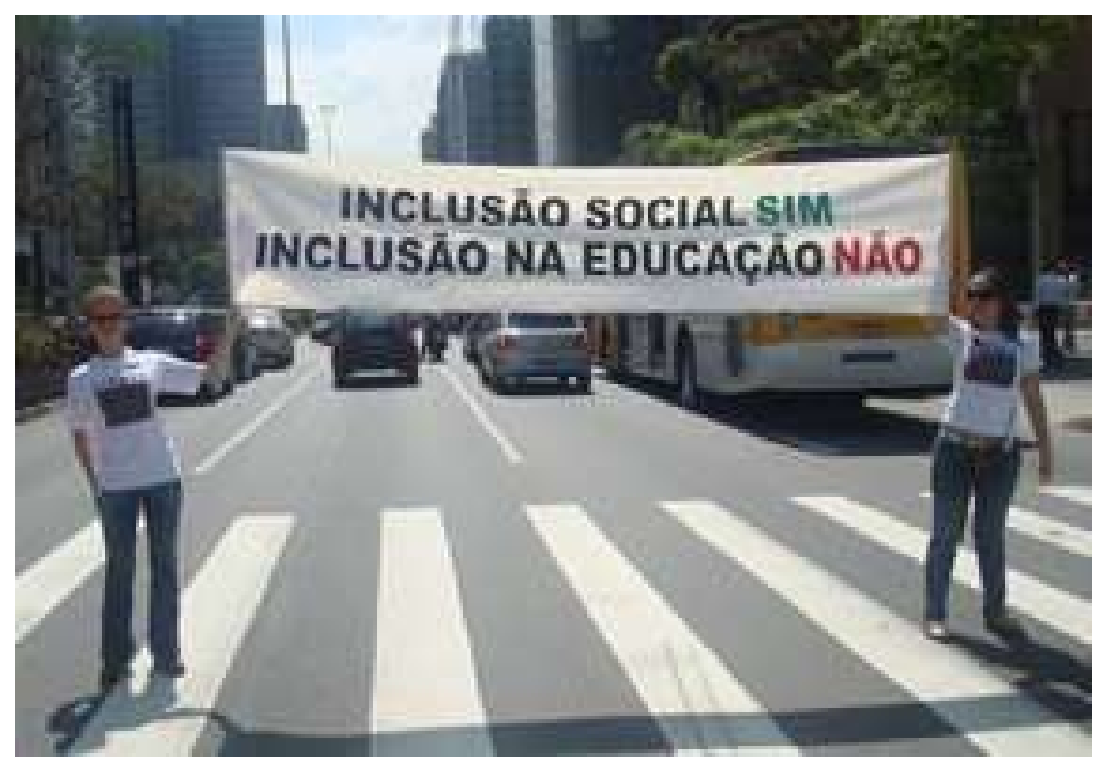

Fonte: SILVA el at, 2009, p. 3. 
Pode-se observar, na foto $\mathrm{n}^{\mathrm{o}} 4$, o posicionamento tanto dos surdos quanto dos ouvintes, na manifestação contra a inclusão dos alunos surdos nas escolas e/ou classes regulares. Silva et. al. (2009) discutiram ainda que, nos discursos realizados na Av. Paulista, era unânime a compreensão de que a inclusão escolar dos surdos nega aos alunos a possibilidade de aprendizagem e, portanto, a equidade educacional propagada pela Política de Educação Especial, na medida em que a Libras não é priorizada nos processos educacionais, além de não ser assegurada a interação entre os alunos ouvintes e surdos e, destes, com professores e funcionários; a interação possível em Libras, ocorre apenas entre os alunos surdos e os TILSP (ou professores interlocutores, como denominado pela secretaria estadual de educação), quando estes estão presentes.

Compreende-se que esta ação coletiva se constituiu em uma rede que envolveu a ASSP, a Feneis, as escolas de surdos públicas e privadas, e outras instituições sociais, em prol de uma finalidade em comum: a defesa das escolas de educação bilíngue para surdos. Por seu intermédio, os surdos mostraram a existência de uma consciência coletiva, construída no decorrer da história dos surdos paulistanos, e estabeleciam um diálogo direto com os movimentos nacionais de surdos que lutavam pela mesma causa. Demonstravam, assim, amadurecimento em suas formas de luta, uma formação que se deu com o passar dos anos e, portanto, uma aprendizagem que foi construída socialmente. Um processo educacional que pode ser entendido como não formal (GOHN, 2010), por não depender da presença de professores e tampouco dos espaços concretos das escolas.

Conforme discutiu Gohn (2010), a educação não formal contribui para a formação cidadã e para o desenvolvimento de "uma cultura política do grupo" que a vivencia; para a "construção e (re)construção de concepção(ões) de mundo e sobre o mundo", para a formação do "indivíduo para a vida e suas adversidades (...) para um sentimento de identidade com uma determinada comunidade" e, portanto, para "a valorização de si próprio" (p. 21). Contribui ainda para a aquisição de "conhecimentos a partir de sua própria prática" (Idem) e por aquelas desenvolvidas pelo grupo de pertencimento.

Ainda segundo Gohn (2010), nos processos de educação não formal, a lógica dos atores coletivos é construída socialmente a partir do compartilhamento de diferentes experiências e dos conhecimentos acumulados pelo grupo, que pode, por seu intermédio, decidir sobre a melhor forma de agir coletivamente a fim de alcançar seus objetivos. Estas decisões envolvem a constituição de uma "cultura política de um grupo" (p. 20), 
construída na convivência com outros na vida cotidiana, no interior de um mesmo grupo, no aconchego de estar entre pessoas que compartilham de um mesmo interesse, e que se mostram livres para definir quem são. Nesta construção social, o grupo pode, portanto, mostrar, autonomamente, suas formas particulares de entender o cotidiano, aprendendo a olhar, a dizer e a ler o mundo de modo a (re)definir, continuamente, a "identidade coletiva do grupo" (p. 20).

Neste contexto de luta política dos surdos, no final do ano de 2009, houve a Conferência Regional - São Paulo da Conferência Nacional de Educação (Conae), na qual representantes de diversas esferas sociais e dos Poderes Públicos discutiram propostas para o Plano Nacional de Educação (PNE), que foram encaminhadas para a Conae realizada em 2010. Na Conferência paulista, conforme Zovico (2010), os surdos foram representados pelo presidente da ASSP - Paulo Vieira, pela diretora da Feneis SP, Moryse Vanessa Saruta, pelo coordenador nacional de acessibilidade para surdos da Feneis-SP - a Neivaldo Augusto Zovico, pelo diretor geral da Associação Brasileira de Surdos-Cegos (Abrasc) - Carlos Jorge Wildhagem Rodrigues, pelo professor surdo Cristiano Koyama, por outros profissionais da área da educação de surdos, TILSP e guiasintérpretes.

Fotografia 6: A comunidade surda no Conae 2010

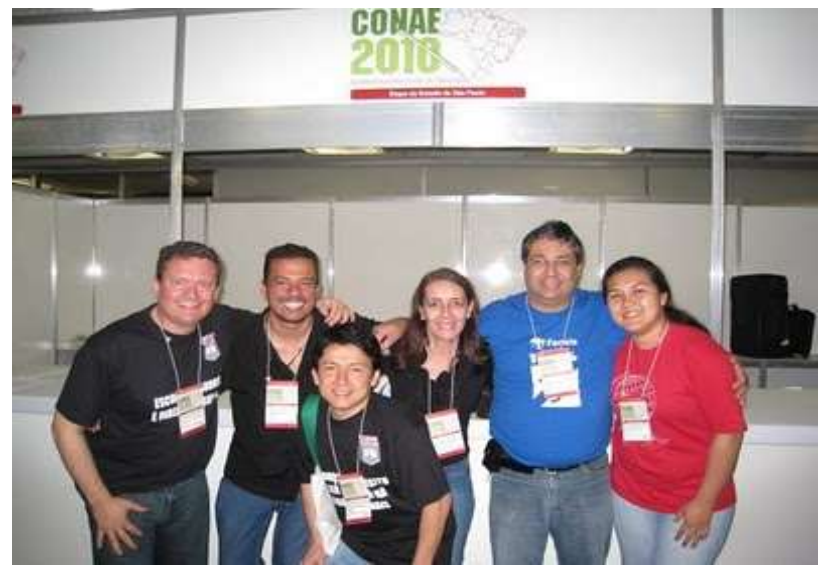

Fonte: Zovico, $2010^{36}$.

Da esquerda para direita: Presidente de ASSP, Paullo Vieira; Intérprete de Libras, Joel Barbosa; professor surdo, Cristiano Koyama; Professora de Derdic, Maria Inês; Coordenador Nacional de Acessibilidade para surdos da Feneis-SP, Neivaldo Zovico; Diretora de Feneis-SP, Moryse Saruta.

\footnotetext{
${ }^{36}$ Disponível em: $<$ http://acessibilidadeparasurdos.blogspot.com.br/2010/02/diretores-da-feneisparticiparam-do.html>. Acesso em 29 jun. 2017.
} 
Segundo Zovico (2010a), logo após a abertura da Conferência Regional, os representantes das comunidades surdas estenderam faixas nas quais assumiam o posicionamento contra a inclusão educacional dos surdos.

Fotografia 7: As faixas das comunidades surdas diante à abertura da Regional da Conae

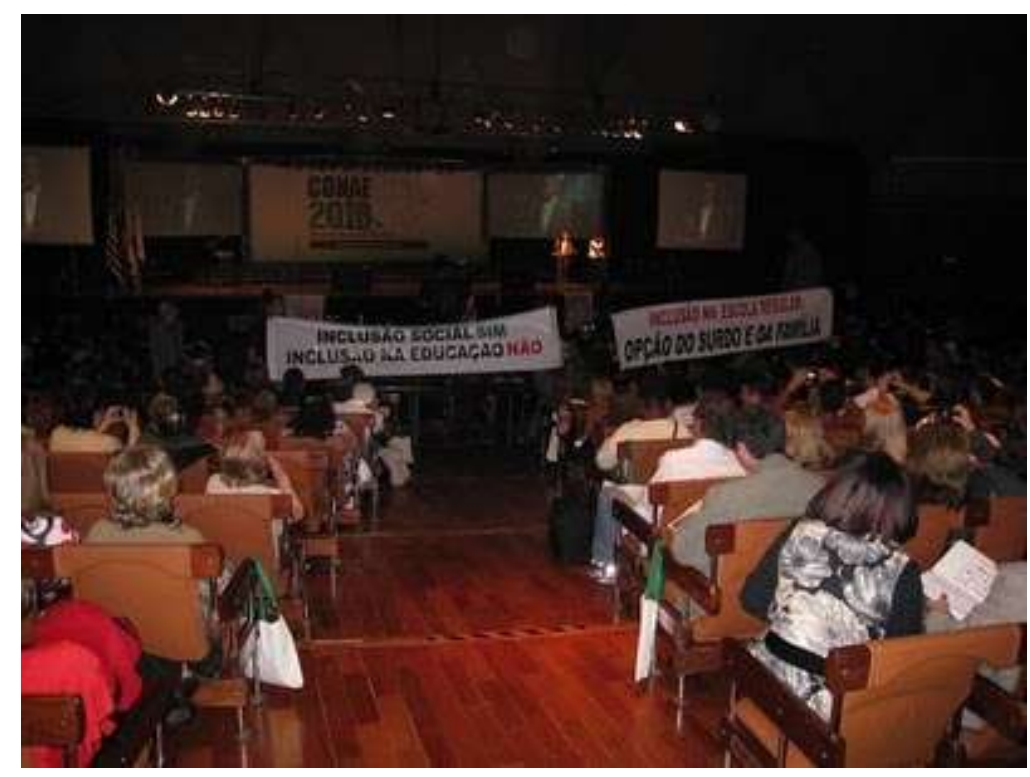

Fonte: Zovico, $2010^{37}$.

Quando a temática "diversidade" entrou em pauta na Conferência, Neivaldo Zovico teve a oportunidade de discorrer sobre a diferença linguística da criança surda e, portanto, em função dela, sobre a necessidade de a educação dos surdos ser realizada em escolas específicas para surdos.

[é] necessário um espaço educacional adequado para sua [da criança surda] aquisição linguística em libras considerando que os cursos de capacitação em libras de 30 horas oferecido aos professores não resolve o problema, afirmou que o que a criança surda necessita é de uma Escola Bilíngue de Surdos (ZOVICO, 2010a).

Como delegados para apresentarem propostas sobre a educação de surdos a serem incluídas no PNE na Conae, foram escolhidos Neivaldo Zovico, coordenador nacional de acessibilidade para surdos e Moryse Vanessa Saruta, diretora da Feneis-SP.

${ }^{37}$ Idem 
Torna-se possível compreender assim, em consonância com Melucci (1989, 2001), a importância de se considerar os atores em todo estudo sobre movimentos sociais, na medida em que apenas eles sabem definir e mostrar suas formas de ação, determinadas pelos contextos sócio-históricos em que estão inseridos.

\section{7 A continuidade do movimento em defesa da Educação Bilíngue para Surdos e a união entre ASSP, Feneis e escolas públicas para a criação das Escolas Municipais da Educação Bilíngue para Surdos (Emebs)}

A sociedade brasileira, no início da década de 2010, dava sinais de melhoras em áreas como a educação, à saúde e à oportunidade de trabalho, graças ao esforço e ao desempenho dos programas sociais dos dois governos de Lula (ANDERSON, 2011; ESPÍNOLA, CAVALCANTE, 2014). Estes programas tiveram continuidade no governo Dilma Rousseff, primeira mulher a assumir o cargo de Presidente da República no Brasil.

Uma das principais preocupações dos governos Lula e Dilma era a educação brasileira, razão pela qual, recursos financeiros do Fundo de Manutenção e Desenvolvimento da Educação Básica e de Valorização dos Profisssionais de Educação foram repassados aos governos estaduais e do Distrito Federal a fim serem investidos nas escolas públicas, ainda consideradas como sendo de baixo desempenho pelo Índice de Desenvolvimento da Educação Básica (Ideb) (ESPÍNOLA, CAVALCANTE, 2014). Outra medida tomada pelos governos petistas, foi a ampla participação propiciada aos profissionais da educação, pais, alunos e líderes de movimentos sociais para discussão e, posterior escolha de delegados para participação na Conae, onde foram debatidos e votados os pontos que comporiam o PNE para o período 2010 a 2020 (PORTAL DE CONAE, 2010) $)^{38}$.

A Conae foi realizada entre o fim do mês de março e o começo do mês de abril de 2010. Os representantes das comunidades surdas e ouvintes que apoiavam a educação bilíngue, apresentaram a seguinte proposta, que foi rejeitada pela plenária:

Garantia às famílias e aos surdos do direito de optar pela modalidade de ensino mais adequado para o pleno desenvolvimento linguístico,

\footnotetext{
$38 \quad$ Disponível em: $<$ http://conae.mec.gov.br/index.php?option $=$ com_content\&view=article\&id=46\&Itemid=57 $>$. Acesso em 15 jul. 2017.
} 
cognitivo, emocional, psíquico, social e cultural de crianças, jovens e adultos, garantindo o acesso à educação bilíngue - utilizando a Língua Brasileira de Sinais (LIBRAS) e a língua portuguesa (CAMPELLO; REZENDE, 2014, p. 74).

Segundo discutiram Campello e Rezende (2014), a equipe da Secretaria de Educação Especial (Seesp/MEC), rebateu a proposta apresentadas pelos surdos argumentando que as escolas específicas para cada deficiência eram segregatórias e contrariavam os princípios da educação inclusiva. No ano seguinte, o MEC, por intermédio da diretora das Políticas Educacionais Especiais anunciou o fechamento do Instituto Nacional de Educação dos Surdos (Ines) para transformá-lo em um centro de formação e de orientação pedagógica para professores atuarem nas escolas regulares que recebiam alunos surdos (CAMPELLO; REZENDE, 2014). Esta informação repercutiu negativamente para as comunidades surdas e para ouvintes que defendiam a educação bilíngue para surdos, ao considerarem este instituto uma referência na história da educação dos surdos.

As comunidades surdas do Rio de Janeiro ante este projeto passaram a se manifestar, de forma cada vez mais intensa, em suas redes sociais e por meio de vídeos postados no YouTube; os vídeos, em sua maioria, filmados por ex-alunos do Instituto, eram carregados de forte emoção e de indignação, uma violência ao que consideravam ser "o Patrimônio Histórico e Cultural da Comunidade Surda Brasileira" (SILVA, ASSENSIO, 2011, p. 2). Estes protestos mobilizaram, rapidamente, as comunidades surdas do Brasil, que passaram a lutar por um objetivo comum: o direito dos alunos surdos estudarem em escolas de educação bilíngue, em todo o território brasileiro (CAMPELLO E REZENDE, 2014). Em maio de 2011, o movimento nacional de surdos protestou diante do Congresso Nacional em Brasília. 
Figura 9: A capa da revista de FENEIS sobre o movimento nacional de defesa das escolas da Educação Bilíngue para surdos na Brasília em 2011

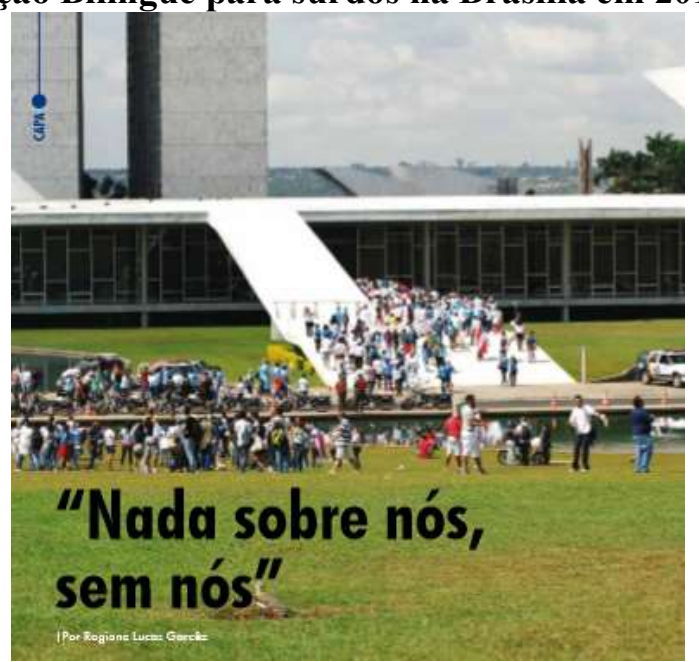

Fonte: Revista da Feneis, n. 44, jun. a ago. 2011, p. 8.

Esse movimento foi liderado por duas mulheres ativistas surda, Mariana Hora e Patrícia Rezende, que realizou um (belo) discurso sobre a importância de se respeitar o direito linguístico dos surdos brasileiros na audiência da Subcomissão de Assuntos Sociais das Pessoas com Deficiência, como pode ser visto na foto tirada do momento do discurso, postado no canal YouTube:

Figura 10: O discurso da líder e ativista surda, Patrícia Rezende

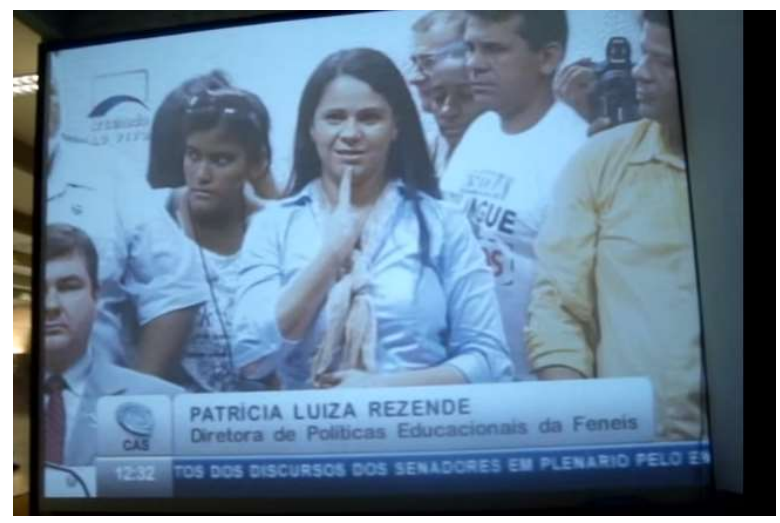

Fonte: LIMA, $2001^{39}$.

\footnotetext{
${ }^{39}$ Disponível em: < https://www.youtube.com/watch?v=qABk4a61Hzk $>$. Acesso em 20.jun. 2017.
} 
Zovico (2014), neste mesmo movimento, ao argumentar sobre o direito dos surdos à educação bilíngue, destacou o Artigo 30, item 4, da Convenção sobre os Direitos das Pessoas com Deficiência: “As pessoas com deficiência farão jus, em igualdade de oportunidades com as demais pessoas, a que sua identidade cultural e linguística específica seja reconhecida e apoiada, incluindo as línguas de sinais e a cultura surda".

No âmbito da capital paulista, no ano de 2010, houve também um movimento em defesa da garantia dos direitos educacionais dos surdos e nova ação coletiva foi organizada pela ASSP, pela Feneis - SP, pelos profissionais das Escolas Municipais de Educação Especial e das três escolas privadas da grande São Paulo, apoiada pelas comunidades surdas paulistanas. Nesse contexto, conforme pode ser observado no blog "Movimento Comunidade Surda de São Paulo" (2010), foram escolhidos delegados surdos para participarem da Conferência Municipal de Educação (CME), na qual foram apresentadas as seguintes propostas: "a manutenção e a reestruturação das escolas de surdos já existentes na cidade; a garantia de presença de professores surdos nas escolas e de profissional intérprete e guia-intérprete para os surdo-cegos; e a criação de cargos de instrutor surdo" (OBSERVATÓRIO DA EDUCAÇÃO, 2010) ${ }^{40}$.

Para estas discussões, foi garantido aos surdos a presença de TILSP; no entanto, conforme relato de Paulo Vieira, presidente da ASSP, a acessibilidade dos surdos à informação naquele espaço foi apenas parcial, pois "faltou iluminação para ver o intérprete, estava um pouco escuro e os surdos fizeram força para ler. Foi um pouco cansativo e, pior, o telão ficou muito escuro por falta de iluminação também" (OBSERVATÓRIO DA EDUCAÇÃO, 2010); apesar disso, as propostas apresentadas pelos surdos na CME foram aceitas graças a forte participação da comunidade surda na Conferência. Esta mobilização e a vitória obtida no município levou Paulo Vieira a fazer o seguinte comentário: "acredito que ajudará muito para que no futuro tenhamos mais líderes surdos que possam dar opiniões sobre seus direitos" (OBSERVATÓRIO DA EDUCAÇÃO, 2010).

No dia 12 de setembro de 2011, na cidade de São Paulo, foi realizado o Seminário Estadual em Defesa das Escolas Bilíngues para Surdos e, em uma ação coordenada pelos professores e lideres surdos Priscila Gaspar e Alexandre Melendes, foram colhidas assinaturas de apoio para que a educação bilíngue para surdos fosse contemplada no Plano

\footnotetext{
${ }^{40}$ Disponível em: < http://www.deolhonoplano.org.br/not0027.html>. Acesso em 15 jul. 2017.
} 
Nacional de Educação (PNE); este documento foi entregue às autoridades presentes no auditório Paulo Kobayashi da Assembleia Legislativa (SILVA; ASSENSIO, 2011). Para este ato, os surdos, pelas redes sociais, organizaram-se para estarem todos vestidos de preto, portando, nas camisas e camisetas, uma fita azul no formato de um laço, com o objetivo de demonstrar o seu luto pela não aceitação das escolas bilíngues para surdos.

Neste mesmo seminário, houve uma mesa redonda composta por um deputado estadual do PV-SP, uma assessora parlamentar do PSDB-SP, diretora da Feneis e pelo presidente da ASSP. Os dois surdos, em nome da comunidade, falaram sobre a reivindicação e pediram que lhes fossem dados respeito e atenção. Ao final, os surdos presentes acenderam velas, demonstrando, por meio delas, sua tristeza em relação às políticas educacionais de inclusão em vigência (SILVA; ASSENSIO, 2011).

Ainda segundo os autores, nova mobilização em defesa das escolas bilíngues foi realizada pelos surdos paulistanos, que organizaram uma Caminhada do dia do Surdo (26 de setembro), que seguiu em direção à Prefeitura de São Paulo. Dois meses depois, foi realizado, no SESC Vila Mariana, o VI Festival Esportivo e Cultural de Alunos Surdos, que, além de contar com a presença das instituições representativas dos surdos, recebeu o então prefeito Gilberto Kassab e o Secretário da Educação do Município de São Paulo. Neste dia foi assinado o Decreto Municipal $n^{0} 52.785 / 11$, que assegurou a manutenção das escolas de surdos existentes no município, que passaram a ser chamadas Escolas Municipais de Educação Bilíngue para Surdos (Emebs), e nelas foram assegurados processos educacionais em Libras (SÃO PAULO, 2011) ${ }^{41}$.

Observa-se, desse modo, que as ações coletivas iniciadas pelos surdos de São Paulo décadas antes, em diálogo com outros movimentos surdos no Brasil, demonstram a possibilidade de continuidade de luta e a garantia legal de alguns de seus direitos. Nesse processo, a identidade coletiva dos surdos, como "falantes" da língua brasileira de sinais, se fortaleceu no decorrer dos anos, bem como tornou possível o desenvolvimento de uma capacidade reflexiva sobre o agir coletivo, que propiciou mudanças sociais nas relações tanto entre atores coletivos dentro da ação coletiva quanto destes com os sistemas sociais (MELUCCI, 2001).

\footnotetext{
${ }^{41}$ Disponível em: $<$ http://www.prefeitura.sp.gov.br/cidade/secretarias/comunicacao/releases/?p=141752>. Acesso em 30.jun. 2017.
} 


\section{CAPÍTULO IV}

\section{CONSIDERAÇÕES FINAIS}

Esta dissertação teve como objetivo compreender o processo histórico das ações coletivas dos surdos da Associação de Surdos de São Paulo (ASSP), entre os anos de 1950 a 2011, período que compreende a fundação desta instituição e a criação das Escolas Municipais de Educação Bilíngue para Surdos (Emebs) na capital paulista. Neste contexto, o estudo buscou entender como surgiram estas ações coletivas e como elas se mantiveram no decorrer do período. Foi desenvolvida à luz da perspectiva teórica de Alberto Melucci (1989, 1994, 2001, 2004), importante sociólogo e pesquisador italiano que dedicou seus estudos à compreensão de como surgiram e se mantiveram diferentes movimentos sociais, focalizando, em suas análises, os atores sociais e suas ações coletivas, considerando os respectivos contextos sócio-históricos e culturais determinantes dos movimentos.

As ações coletivas dos surdos paulistanos que possibilitaram a fundação da ASSP tiveram início na década de 1950, época em que um grupo de surdos, envolvido com práticas esportivas, teve a oportunidade de conhecer a Asociación de Sordosmudos de Ayuda Mutua (ASAM), em Buenos Aires (Argentina), e de estabelecer e manter relações sociais com aquela instituição. Nesta vivência, foi possível ao grupo compreender a organização e as funções de um espaço como aquele e, a partir de formação de um nós, com um interesse em comum, pode agir coletivamente a fim de ser criada uma unidade (com objetivo, meios e ambiente) responsável pela primeira ação coletiva dos surdos: a fundação da ASSP.

Este espaço, destinado principalmente, mas não exclusivamente, aos surdos, e fortemente marcado pela promoção esportiva (com especial ênfase ao futebol), com o passar do tempo, ganhou um significado importante na formação das comunidades surdas que, nas relações sociais nele estabelecidas e naquelas da vida cotidiana, passaram a partilhar uma identidade coletiva, conforme compreendido por Melucci (1989, 2001, 2004). 
Neste momento da história, a língua de sinais, na origem da ASSP, não era tema e/ou foco de discussão, pois o que unia os surdos que dela participavam era a possibilidade de ter um espaço físico para que eles e seus familiares pudessem se encontrar, realizar festas e estar reunidos em datas comemorativas, elaborar projetos e desenvolver atividades de lazer; a ASSP constituía-se, portanto, segundo enunciou Mario Pimentel na entrevista para esta dissertação, como a "casa dos surdos". Nesta "casa" a comunicação era livre, realizando-se da forma como seus "donos" se sentissem bem. Nela também se tornou possível a constituição de um vínculo social, construído no decorrer de suas vivências diárias, relações eu - outro(s) de reconhecimento recíproco e de fortalecimento de um sentimento de pertencimento àquele espaço.

Além do aspecto social, a prática esportiva, que motivou a fundação da ASSP, intensificava a convivência entre os surdos, tanto daqueles que partilhavam aquele espaço social quanto com surdos de outras localidades do Brasil, fato que foi determinante para que outras associações de surdos, no estado de São Paulo e em outros estados, fossem também fundadas. Entende-se assim, que estes novos espaços coletivos se tornaram possíveis, dado o conhecimento e vivência acumulados pelos fundadores e membros da ASSP, que puderam orientar outros grupos de surdos sobre a necessidade de negociações e renegociações a fim de ser possível a tomada de decisão e definição de novos atores/ações coletivas, possibilitando, desse modo, o início de relações intrínsecas entre eles. Pode-se dizer, portanto, em consonância com Melucci (1989), que o ator coletivo ASSP, possibilitou redes de relações sociais formais e/ou informais entre diferentes atores coletivos surdos, envolvendo pessoas que partilhavam diferentes experiências de vida, conhecimentos e vivências socioculturais.

Observou-se, no entanto, que, por muitos anos, as diferentes ações coletivas surdas, sempre apoiadas pela e com a participação ativa de alguns líderes da ASSP, permaneceram em latência. Foi um período em que foi possível a expansão dos envolvimentos pessoais e o fortalecimento das relações de solidariedade entre os diferentes atores sociais surdos, criando-se, nestes processos, um sistema de oportunidade e de vinculo, determinante para que novas ações coletivas tivessem início, ao se considerar, conforme discutiu Melucci (2001) que nenhum movimento surge sozinho ou por acaso. Destaca-se a fundação das Federações Esportivas de Surdos em três estados brasileiros (São Paulo, Rio de Janeiro e Minas Gerais) e seu reconhecimento pela 
Comissão Internacional dos Esportes de Surdos (CISS), a fim de ser possível que a Confederação Brasileira de Desportos de Surdos (CBDS) se tornasse realidade.

No entanto, no decorrer dos quase cinco anos até que o Conselho Nacional de Desporto (CND) autorizasse o funcionamento da CBDS, alguns surdos, envolvidos nesta ação, passaram a participar de outros movimentos. Destacaram-se, neste estudo e com base nas discussões de Brito (2013), os Encontros Nacionais das Pessoas Deficientes, promovidos em função da escolha, pela ONU, do ano de 1981, como o Ano Internacional das Pessoas Deficientes. No terceiro e último Encontro realizado, em 1983, foi aceita a proposta para que fossem criadas federações específicas para cada tipo de deficiência. Neste contexto, as diferentes associações existentes, incluindo a ASSP, foram convocadas para participarem da Comissão Nacional de Defesa dos Direitos dos Deficientes Auditivos. A rede de relações criadas nesse processo foi então determinante para que novo movimento fosse iniciado pelas comunidades brasileiras: o ingresso de representantes surdos na, então existente, Federação Nacional de Educação e Integração de Deficientes Auditivos (Feneida), que não se tornou realidade nas primeiras negociações.

Observa-se assim, em consonância com o exposto por Melucci (2001), que a ação coletiva iniciada com a fundação da ASSP, fragmentou-se e deu origem a outras ações e a outros movimentos sociais surdos, (re)criados a partir dos novos contextos sóciohistóricos e culturais que os surdos vivenciavam; movimentos que se transformavam e que se renovavam a partir de outros objetivos comuns, determinando a manutenção das ações coletivas surdas no decorrer do tempo. Neste contexto, mais do que um espaço de convivência e de práticas de esportes, buscava-se espaços nos quais os surdos se tornassem protagonistas e nos quais a língua de sinais figurasse como fundante de uma identidade coletiva surda.

Apesar de, no conjunto de sua obra, Melucci, não mencionar, especificamente, as questões geracionais quando discutiu as mudanças e a heterogeneidade das ações coletivas, entende-se ser este aspecto importante também para a manutenção e continuidade dos movimentos sociais surdos. Para esta discussão, no entanto, torna-se necessário mobilizar o conceito de geração conforme compreendido por Mannhein (1928 apud WELLER, 2010). Para o autor, o fenômeno geracional deve ser entendido no sentido de um processo relacional dinâmico que envolve, em um mesmo tempo, sujeitos com diferentes experiências de vida e conhecimentos, que de forma ativa, exercerão 
influências recíprocas na constituição de um conjunto de ações, de reações e de posições políticas, a partir de um determinado contexto sócio-histórico, e que serão determinantes para o estabelecimento de práticas coletivas. Estas influências, no decorrer das ações coletivas, podem propiciar:

a) Constante irrupção de novos portadores de cultura: a entrada de novas pessoas no coletivo permite vitalidade e dinamicidade social, podendo levar a perda de bens culturais acumulados. No entanto, Mannheim compreende que este processo pode também levar à revisão do campo, "nos ensina a esquecer o que já não é útil e a desejar o que ainda não foi conquistado" (MANNHEIM, 1928, apud WELLER, 2010, p. 212).

b) Saída dos antigos portadores de cultura: promove a memória ou a recordação social ao mesmo tempo em que torna possível o esquecimento do que deixou de ser significativo/necessário. Para Mannheim, há duas formas de memória na qual o passado se faz presente: a primeira, como "modelo consciente" que orienta as ações dos indivíduos na sociedade; a segunda como uma espécie de ferramenta que condensa as experiências, percebida por meio da recordação das experiências.

c) Limitação temporal da participação de uma conexão geracional no processo histórico: possibilidade de indivíduos nascidos em diferentes épocas de vivenciarem os mesmos acontecimentos e experiências semelhantes, e de processa-los de forma parecida;

d) Necessidade de transmissão constante dos bens culturais acumulados: que ocorre por meio da interação e troca de papéis entre indivíduos que estão no mesmo grupo e que possuem diferentes perspectivas de mundo, promovendo o que Mannheim denominou gerações intermediárias. Para o autor, a interação entre indivíduos de posições geracionais distintas não significa que os velhos devam ensinar e os novos aprender; os estudos sobre geração devem destacar "o conhecimento implícito acumulado e transmitido de geração para geração com suas devidas releituras e reinterpretações" e "a necessidade de compreensão do problema das gerações como um processo dinâmico" (WELLER, 2010, p. 213). 
Esta última experiência é relevante para a compreensão do processo de aprendizagem, visto que por meio do compartilhamento de conhecimentos construídos e acumulados em um determinado tempo e espaço por diferentes sujeitos, abre-se a possibilidade de continuidade de interações "entre distintos fatores constitutivos de gerações" (WELLER, 2010, p. 213). Ao se entender que aprendizagem não se restringe às instituições concretas, como por exemplo, às escolas, mas é um processo que se dá por meio dos conhecimentos e experiências acumulados socialmente, pode-se afirmar que os movimentos sociais constituem-se também em "espaços" de educação não-formal, ao propiciarem um processo educacional contínuo e dinâmico sobre formas de agir, dizer e pensar e, portanto, o desenvolvimento de uma consciência social, cultural e política de grupo, enriquecendo, desse modo, as experiências de vida daqueles que deles participam nas diferentes esferas sociais.

Entende-se assim, em consonância com Gohn (2010), que a educação não formal se constitui em um modo de aprender "no mundo da vida, via os processos de compartilhamento de experiências, principalmente em espaços e ações coletivas cotidianas" (GOHN, 2010, p.16). Ela se constitui, portanto, a partir das condições e intenções dos indivíduos; é processual e ininterrupta, à medida que a aprendizagem se dá nas relações sociais sendo, ao mesmo tempo, individual e grupal. Por ser socialmente constituída, não depende da presença de professores para ocorrer, assim como não precisa de espaços concretos, já que se desenvolve “em territórios que acompanham as trajetórias de vida dos grupos e indivíduos, fora das escolas, em locais informais, locais onde há processos interativos" (GOHN, 2010, p. 17).

Nesse sentido, entende-se que as experiências construídas e acumuladas no decorrer dos anos pela ASSP e sua influência e participação em outras ações e movimentos sociais, em especial o processo de criação da CBDS, constituiu-se em processos de aprendizagem para que novos atores sociais surdos surgissem. Destaca-se a eleição da primeira presidente surda da Feneida, que passou a ser chamada Federação Nacional de Educação e Integração dos Surdos (Feneis), no Rio de Janeiro, e teve seu quadro diretor composto por pessoas surdas; a instituição da Comissão Paulista para a Defesa dos Direitos dos Surdos (Copadis), na cidade de São Paulo, que embora liderada por uma pesquisadora ouvinte, contava com o apoio das comunidades surdas, por defender o uso e o reconhecimento da Libras nos diferentes espaços sociais, 
principalmente nas escolas de surdos; e o movimento, também na cidade de São Paulo, envolvendo surdos e ouvintes, que lutavam pela criação de escolas para surdos em todas as regiões da capital paulista.

Reitera-se que estas ações foram possíveis pela história de luta e de organização das comunidades surdas, que, por meio do conhecimento e da experiência partilhada pelos diferentes atores coletivos existentes, puderam projetar ações coletivas futuras, como os movimentos para o reconhecimento da Libras e pela defesa da educação bilíngue para surdos. Este processo iniciado com a fundação da ASSP e, posteriormente, de diferentes associações, da CBDS e da Feneis, foi possível pelo estabelecimento de uma rede de movimento, necessária para a construção de um conjunto maior de atores sociais. Esta rede foi determinante para a organização de novas ações coletivas, que passaram a pressionar os Poderes Públicos a fim de conseguirem, ao romper com o sistema, transformações sociais: o direito dos surdos de serem reconhecidos como minoria socioculturais e linguística. É nesse momento, portanto, que os movimentos surdos ganham visibilidade.

A maior participação política e social dos surdos em defesa de seu direito se deu a partir do ano de 1999 e manteve-se (e ainda se mantém) no decorrer das décadas de 2000 e 2010, a partir da construção de uma capacidade reflexiva coletiva, determinante de uma maior interpretação dos sentidos de suas lutas e, portanto, para a construção de estratégias a fim de alcançarem seus objetivos. Na cidade de São Paulo, este movimento possibilitou o reconhecimento da importância da Libras para os processos educacionais dos surdos por meio da Lei Municipal $n^{\circ}$ 13.304/02 e, no mesmo ano, por meio do reconhecimento legal da Libras em âmbito nacional, para uso em todos os espaços públicos e privados de atendimento à população, por intermédio da Lei Federal $\mathrm{n}^{\circ} 10.436 / 2002$. Esta Lei, ao ser regulamentada pelo Decreto $\mathrm{n}^{\circ} 5.626 / 2005$, assegurou ainda, pelo menos na educação infantil e nos anos iniciais do ensino fundamental, a educação bilíngue para surdos.

No entanto, aproximadamente três anos e meio após a publicação do Decreto, cujas disposições deveriam ser postas em prática no prazo de 10 anos, o Governo Federal publicou a Política Nacional de Educação Especial na Perspectiva da Educação Inclusiva que, contrariando os documentos oficiais anteriores, orienta a todos os sistemas de ensino a incluírem, nas salas de aula regular, todos os alunos, inclusive os surdos. A 
partir desta perspectiva de educação, muitas escolas de surdos foram fechadas ou ameaçadas de fechamento. Este contexto acabou por determinar nova mobilização e, portanto, que novo movimento social fosse iniciado. Entende-se assim, em consonância com Melucci (2001), que são as crises e/ou conflitos criados pela sociedade que incitam e promovem os movimentos sociais a fim de se opor e/ou propor novas mudanças sociais.

Desse modo, a partir das determinações federais em relação a educação dos surdos, que repercutiram nas esferas estaduais e municipais, a ASSP em parceria com a Feneis e com outros atores coletivos, intensificou a luta em prol da educação bilíngue para surdos, enfrentando, desse modo, outras coletividades que se opunham a esta modalidade educacional, única que garante os direitos linguístico e cultural dos surdos. Um desses espaços foi a Conferência Regional - São Paulo da Conferência Nacional de Educação (Conae) e, posteriormente, a própria Conae, onde as propostas dos surdos não foram, em princípio, aceitas.

Apesar disso, as comunidades surdas de São Paulo mantiveram-se unidas, graças a intensa participação da ASSP e da Feneis - SP e, com o apoio das escolas municipais e particulares de surdos existentes na cidade, iniciaram novas ações coletivas em defesa da manutenção das escolas de surdos e da implantação da educação bilíngue nestes espaços sociais. Estas levaram à presença e participação dos líderes surdos na Conferencia Municipal de Educação (CME) que culminou no Decreto Municipal nº 52.785/2011, que assegurou a educação proposta pelos surdos e transformou as Escolas Municipais de Educação Especial (Emees) em Escolas Municipais da Educação Bilíngue para Surdos (Emebs).

Neste contexto, pode-se dizer que a ASSP exerceu um papel de protagonista na história dos surdos da cidade de São Paulo, além de ter sido fundamental para a formação de novos atores coletivos e para o estabelecimento de uma rede de solidariedade e de movimentos sociais.

A história de lutas dos surdos ainda não terminou e, pode-se dizer, ao considerar os estudos sobre movimentos sociais, que nunca irá terminar, na medida em que os novos conflitos sociais surgem, incitando os diferentes atores sociais a desenvolverem novas compreensões e novas estratégias de agir coletivo, a fim de assegurar o interesse comum de uma coletividade. 


\section{REFERÊNCIAS BIBLIOGRAFICAS}

ABREU, A. Depoimento Mario Pimentel. Parte 1. 27 mar. 2016a. Disponível em: $<$ https://www.youtube.com/watch?v=70vpX2ML-q4 $>$. Acesso em 10 abr. 2017.

Associação dos Surdos Mario Pimentel. Parte 2. 27 mar. 2016b. Disponível em: $<\underline{\text { https: }}$ //www.youtube.com/watch?v=tFE6xkYRcMM $>$. Acesso em 10 abr. 2017.

CBDS Fundador Mario Julio Pimentel. Parte 3.27 mar. 2016c. Disponível em:

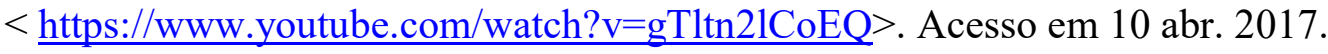

. Brasil - Senhor Mario Julio Pimentel CHN. Parte 4. 27 mar. 2016d. Disponível em: < https://www.youtube.com/watch?v=QH5UY0jv_28 $>$. Acesso em 11 abr. 2017.

Documentos, ofícios e recortes de jornais. Parte 5. 27 mar. 2016e. Disponível em: < https://www.youtube.com/watch?v=ZIY7B7uwO6U> . Acesso em 11 abr. 2017.

. História - Esporte dos Surdos e líderes Surdos CBDS. 16 ago. 2016f. Disponível em: $<$ https: $/ /$ www.youtube.com $/$ watch? $\mathrm{v}=$ C0ABUU31Qs\&t=122s $>$. Acesso em $11 \mathrm{abr}$. 2017.

ALEXANDER, Jeffrey C. Ação coletiva, cultura e sociedade civil: secularização, atualização, inversão, revisão e deslocamento do modelo clássico dos movimentos sociais. Revista Brasileira de Ciências Sociais, São Paulo, v. 13, n.37, jun. 1998. Disponível em: < http://www.scielo.br/scielo.php?script=sci abstract\&pid=S0102$\underline{69091998000200001 \& \operatorname{lng}=\mathrm{en} \& n \mathrm{~nm}=\mathrm{iso} \& \mathrm{t} \operatorname{lng}=\mathrm{pt}>}$. Acesso em 04 jul. 2016.

ANDERSON, Perry. O Brasil de Lula. Tradução de Alexandre Barbosa de Souza e Bruno Costa. Novos Estudos - CEBRAP, São Paulo, n. 91, nov. 2011. Disponível em: < http://www.scielo.br/scielo.php?script $=$ sci arttext\&pid=S0101$33002011000300002 \&$ lang=pt $>$. Acesso em 26 jun.2017.

ASSÊNSIO, Cibele B. Comunidade Surda: notas etnográficas, lideranças e tensões. 2015. 191f. Dissertação (Mestrado em Antropologia). Universidade de São Paulo, São Paulo. Disponível em: $<$ http://www.teses.usp.br/teses/disponiveis/8/8134/tde01032016-145531/pt-br.php >. Acesso em 25 jun. 2016.

ASSOCIAÇÃO DE SURDOS DE SÃO PAULO. Reformulação do Estatuto e Eleição. Caderno de Ata n $^{\circ}$ 8, 50 fls, 14 dez. 1986 a 19 nov. 1998, p.15-28.

. Promoção do curso de Linguagem de Sinais. Caderno de Ata $n^{\circ} 8 b, 50$ fls, 14 dez. 1986 a 16 jul. 1995, p. 10.

BAKHTIN, Mikhail M./VOLOCHINOV, Valentin. Marxismo e Filosofia da Linguagem: problemas fundamentais do método sociológico na ciência da linguagem. 13 ${ }^{\mathrm{a}}$ ed. Trad., Michel Lahud; Yara Frateschi Vieira. São Paulo: Editora Hucitec, 2009.

Estética da criação verbal. São Paulo: Martins Fontes, 6a ed. Trad., Paulo Bezerra. São Paulo: Martins Fonte, 2011. 
Questões de literatura e de estética: a teoria do romance. $7^{\mathrm{a}} \mathrm{ed}$. Trad. Aurora Fornoni Bernardini, José Pereira Júnior, Augusto Góes Júnior, Helena Spryndis Nazário, Homero Freitas de Andrade. São Paulo: Editora Hucitec, 2014.

BAUMAN, Zygmunt. Modernidade líquida. Tradução de Plínio Dentzien. Rio de Janeiro: Jorge Zahar, 2001.

BITTAR, Marisa; BITTAR, Mariluce. História de Educação no Brasil: a escola pública no processo de democratização da sociedade. Disponível em: < https://dialnet.unirioja.es/descarga/articulo/4864688.pdf.>. Acesso em 27 abr. 2016.

BOMENY, Helena. E ele voltou... O segundo governo: a educação no segundo governo Vargas. CPDOC, São Paulo, 2004. Disponível em: < http://cpdoc.fgv.br/producao/dossies/AEraVargas2/artigos/EleVoltou/Educacao>.

Acesso em 26 abr.2017.

BRASIL. Constituição dos Estados Unidos do Brasil, de 18 de setembro de 1946. Disponível

em: $<$ http://www.planalto.gov.br/ccivil 03/constituicao/constituicao46.htm $>$. Acesso em 02 jan 2017.

Lei n ${ }^{0}$ 4.024, de 20 de dezembro de 1961. Fixa as Diretrizes e Bases da Educação Nacional. Disponível em: $<$ http://www2.camara.leg.br/legin/fed/lei/1960-1969/lei-402420-dezembro-1961-353722-publicacaooriginal-1-pl.html>. Acesso em 14 mai. 2017.

. Constituição da República Federativa do Brasil, Emenda Constitucional n.1, de 17 de outubro de $1969 . \quad$ Disponível em: $<$ http://www.planalto.gov.br/ccivil_03/constituicao/constituicao67.htm>. Acesso em 13 jul.2016.

. Lei n. 5.692, de 11 de agosto de 1971. Fixa Diretrizes e Bases para o ensino de $1^{\circ} \mathrm{e} 2^{\circ}$ graus, e dá outras providências. Disponível em:

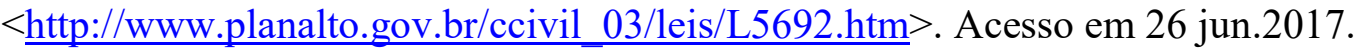

Decreto n. 72.425, de 3 de julho de 1973. Cria o Centro Nacional de Educação Especial (CENESP), e dá outras providências. Disponível em: $<$ http://www2.camara.leg.br/legin/fed/decret/1970-1979/decreto-72425-3-julho-1973420888-publicacaooriginal-1-pe.html $>$. Acesso em 30 jun.2017.

Disponível

Constituição da República Federativa do Brasil, de 5 de outubro de 1988. $<$ https://www2.senado.leg.br/bdsf/bitstream/handle/id/518231/CF88_Livro_EC91_2016 .pdf?sequence $=1>$. Acesso em 30 jun.2017.

Declaração de Salamanca: sobre princípios, políticas e práticas na área das necessidades educativas especiais. Disponível em: $<$ http://portal.mec.gov.br/seesp/arquivos/pdf/salamanca.pdf $>$. Acesso em 26 jun.2017.

Lei n. 9.394, de 20 de dezembro de 1996. Estabelece as diretrizes e bases da educação nacional. Disponível em: $<$ http://www.planalto.gov.br/ccivil_03/leis/L9394.htm>. Acesso em 28 jun.2017. 
. Lei n. 10.436, de 24 de abril de 2002. Dispõe sobre a Língua Brasileira de Sinais - Libras e dá outras providências. Disponível em: $<$ http://www.planalto.gov.br/ccivil 03/leis/2002/110436.htm>. Acesso em 29 jun.2017.

. Decreto n. 5.626, de 22 de dezembro de 2005. Regulamenta a Lei ${ }^{\circ} 10.436$, de 24 de abril de 2002, que dispõe sobre a Língua Brasileira de Sinais - Libras, e o art. 18 da Lei $\mathrm{n}^{\circ} 10.098$, de 19 de dezembro de 2000. Disponível em: $<$ http://www.planalto.gov.br/ccivil 03/ ato2004-2006/2005/decreto/d5626.htm>.

Acesso em 29 jun.2017.

Ministério da Educação. Prolibras - Programa Nacional para a Certificação de Proficiência no Uso e Ensino da Língua Brasileira de Sinais - Libras e para a Certificação de Proficiência em Tradução e Interpretação da Libras/Língua Portuguesa. Disponível em: $<$ http://portal.mec.gov.br/par/194-secretarias-112877938/secad-educacaocontinuada-223369541/17436-prolibras-programa-nacional-para-a-certificacao-deproficiencia-no-uso-e-ensino-da-lingua-brasileira-de-sinais-libras-e-para-a-certificacaode-proficiencia-em-traducao-e-interpretacao-da-libraslingua-portuguesa-novo $>$. Acesso em 16 jul.2017.

. Política Nacional de Educação Especial na Perspectiva da Educação Inclusiva. Brasília: MEC/SEESP, 2008. Disponível em: $<$ http://portal.mec.gov.br/arquivos/pdf/politicaeducespecial.pdf $>$. Acesso em 30 jun.2017.

. Secretaria de Direitos Humanos. Secretaria Nacional de Promoção dos Direitos da Pessoa com Deficiência. Convenção sobre os Direitos das Pessoas com Deficiência. Disponível

em: $<$ http://www.pessoacomdeficiencia.gov.br/app/sites/default/files/publicacoes/conve ncaopessoascomdeficiencia.pdf $>$. Acesso em jul.2017.

BRITO, Fábio B. O movimento social surdo e a campanha pela oficialização da língua brasileira de sinais. 2013. 275f. Tese (Doutorado em Educação), Universidade de São Paulo, São Paulo. Disponível em:

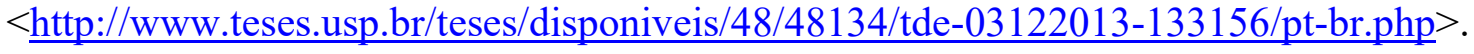
Acesso em 30 jun. 2016.

; NEVES, Sylvia Lia G.; XAVIER, André N. O movimento surdo e sua luta pelo reconhecimento da Libras e pela construção de uma política linguística no Brasil. In: ALBRES, Neiva A; NEVES, Sylvia Lia G. (Orgs). Libras em estudo: política linguística. São Paulo: Feneis, 2013, p. 67-103.

BRITO, Lucinda Ferreira. Bilinguismo e Surdez. Trabalho em Linguística Aplicada, n. 14, p. 89-100, jul. a dez. 1989. Disponível em: < http://revistas.iel.unicamp.br/index.php/tla/article/view/3695/4421>. Acesso em 4 jul. 2017.

BUENO. José Geraldo Silveira. Educação Especial Brasileira: integração/segregação do aluno diferente. 2 ed. São Paulo: EDUC, 2004.

CABRAL, Wagner. História ASURJ. 01 fev. 2012. Disponível em: $<$ http://wavacabral.blogspot.com.br/2012/02/historia-asurj.html $>$. Acesso em 28 jun. 2017. 
CAVALCANTE, Meire. Pela educação inclusiva, vamos com Dilma 13!. Inclusão já: em defesa do direito à educação inclusiva [Oline]. 14. Out. 2014. Disponível em: $<$ https://inclusaoja.com.br/category/notas-de-apoio/>. Acesso em 29 jun. 2017.

CAMPELLO, Ana Regina; REZENDE, Patrícia Luiza Ferreira. Em defesa da escola bilíngue para surdos: a história de lutas do movimento surdo brasileiro. Educar em Revista. Curitiba: Editora UFPR, n. 2, 2014, p. 71-92. Disponível em: < http://www.scielo.br/pdf/er/nspe-2/06.pdf > . Acesso em 02. Jun. 2017.

CUNHA, Marcus Vinicius da. A Educação no Período Kubitschek: os Centros de Pesquisas do Inep. Revista Brasileira de Estudos Pedagógicos, Brasília, v. 83, n. 203/204/205, p. 127-140, jan./dez. 2002. Disponível em: $<$ http://rbep.inep.gov.br/index.php/rbep/article/view/1294>. Acesso em 20 dez. 2016.

FEIXA, Carles; LECCARDI, Carmem. O conceito de geração nas teorias sobre juventude. Revista Sociedade e Estado [online], 2010, v. 25, n. 2, p. 185-204. Disponível em: $\quad<\quad$ http://www.scielo.br/scielo.php?script=sci abstract\&pid=S010269922010000200003\&lng=en\&nrm=iso\&tlng=pt $>$. Acesso em 1 ago. 2016.

FÉLIX, Eliane M. Educação Inclusiva: possibilidades e ambiguidades de uma prática. 2009. 37f. Monografia (Licenciatura em Pedagogia), Universidade Candido Mendes, Rio de Janeiro. Disponível em: < http://www.avm.edu.br/docpdf/monografias_publicadas/graduacao/P00371.pdf $>$.

Acesso em 9 nov. 2016.

FAUSTO, Boris. História Concisa do Brasil. 2 ed. São Paulo: Editora da Universidade de São Paulo, 2009.

FERREIRA JR, Amarilio; BITTAR, Marisa. Educação e ideologia tecnocrática na ditadura militar. Cadernos CEDES [online], v. 28, n. 76, 2008, p. 333-355.

FREITAS, José Cleber; SAUL, Ana Maria; SILVA, Antonio Fernando Gouvea de. Educação na cidade de São Paulo (1989 a 2000). 2 ed. São Paulo: Pólis/PUC-SP, 2002, p. 40. Disponível em: < http://www.polis.org.br/uploads/849/849.pdf> $>$. Acesso em 25 jun. 2017.

GHIRALDELLI, Paulo. História da educação brasileira. $3^{\mathrm{a}}$ ed. São Paulo: Cortez, 2008.

GOHN, Maria da Glória. Teorias dos Movimentos Sociais: paradigmas clássicos e contemporâneos. São Paulo: Ed. Loyola, 1997.

. Movimentos Sociais e Educação. 5 ed. São Paulo: Cortez Editora, 2005.

Educação não formal e o educador social: atuação no desenvolvimento de projetos sociais. São Paulo: Cortez, 2010.

. Movimentos sociais na contemporaneidade. Revista Brasileira de Educação, v. 16, n. 47, mai-ago. 2011. Disponível em: $<$ http://www.scielo.br/scielo.php?script=sci arttext\&pid=S1413-

$24782011000200005 \&$ lang=pt $>$. Acesso em 10 jul. 2016.

GIL, Antonio Carlos. Métodos e técnicas de pesquisa social. $6^{\mathrm{a}}$ ed. São Paulo: Atlas, 2008. 
GOMES, Romeu. Análise e interpretação de dados de pesquisa qualitativa. In: MINAYO, Maria Cecília de Souza (org.). Pesquisa social: teoria, método e criatividade. $34^{\mathrm{a}}$ ed. Petrópolis, RJ: Vozes, 2015, p. 79-108.

GONZÁLEZ, Rodrigo. Historia Ilustrada de La Comunidad Sorda: De la antiguidad a nuestros dias. Colección Cultura Sorda. Montevideo, Uruguay: Universidad de La Republica, 2013.

GOSS, Karine P.; PRUDENCIO, Kelly. O conceito de movimentos sociais revisitado. Revista Eletrônica da Pós-Graduação em Sociologia Política da UFSC, v. 2, n. 1. Santa Catarina, jan.-jul, 2004, p. 75-91. Disponível em: < https://periodicos.ufsc.br/index.php/emtese/article/view/13624>. Acesso em 01 out. 2016.

GOULART, Flavio A. de Andrade. Representações Sociais, Ação Política e Cidadania. Caderno de Saúde Pública, v. 9, n. 4. Rio de Janeiro, out.- dez, 1993. Disponível em acesso: $<\quad$ http://www.scielo.br/scielo.php?script=sci arttext\&pid=S0102311X1993000400008>. Acesso em 15 out. 2016.

JANNUZZI, Gilberta de Martino. A educação do deficiente no Brasil: dos primórdios ao início do século XXI. 3 ed. Campinas, SP: Autores Associados, 2012.

JESUS, Gilmar Mascarenhas de. Várzeas, operários e futebol: uma outra geografia. Geographia [online]. Revista do Programa de Pós-Graduação em Geografia da UFF, v. 4, n. $8, \quad 2002, \quad$ p. 1-9. Disponível em: < http://www.geographia.uff.br/index.php/geographia/article/view/90>. Acesso em 20 mar. 2016.

CUNHA JUNIOR, Elias Paulino da. I Conferência dos Direitos e Cidadania dos Surdos do Estado de São Paulo. 4 abr. 2017. Disponível em:

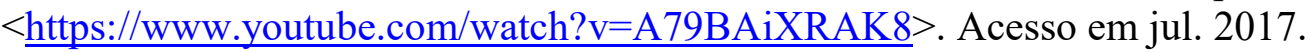

LANA JÚNIOR, Mario Cléber Martins. (Comp.). História do movimento político das pessoas com deficiência no Brasil. Brasília: Secretaria Nacional de Promoção dos Direitos das Pessoas com Deficiência, 2004.

LIMA, Mirian K. L. de. Movimento Social MAP: como emergente paradigma transfronteiriço na Amazônia Sul Ocidental. 2008. 88f. Dissertação (Mestrado em Direito), Universidade Federal de Santa Catarina, Santa Catarina. Disponível em acesso: $<$ http://www.egov.ufsc.br/portal/sites/default/files/anexos/33955-44742-1-PB.pdf $>$.

Acesso em 07 jul. 2016.

LODI, Ana Claudia Balieiro. Educação Bilíngue para Surdos e Inclusão segundo a Política Nacional de Educação Especial e o Decreto no 5.626/05. Educação e Pesquisa, v.39, n.1, jan./mar., 2013. Disponível em: $<$ http://www.scielo.br/scielo.php?script=sci arttext\&pid=S1517-97022013000100004 $>$. Acesso em 30 abr. 2017.

Declaraciones de UNESCO, educación de sordos y educación inclusiva: un de la política nacional de educación de Brasil. Psicología, Conocimiento y Sociedad, v. 4, n. 2 , 2014 ,

p. 261-294.

Disponível

em: 
http://revista.psico.edu.uy/index.php/revpsicologia/article/view/213 > . Acesso em 19 jun. 2014.

MARCÍlIO, Maria Luiza. História da Escola em São Paulo e no Brasil. São Paulo: Imprensa Oficial do Estado do São Paulo - Instituto Fernand Braudel, 2005.

MAZZOTTA, Marcos J. S. Educação Especial no Brasil: História e políticas públicas. $6^{\text {a }}$ ed. São Paulo: Cortez, 2011.

MELUCCI, Alberto. Um objeto para os movimentos sociais? Revista de Lua Nova, n. 17.

São Paulo: jun. 1989. Disponível em:

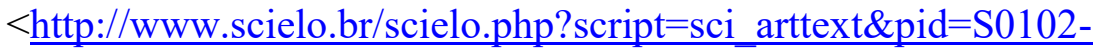

$\underline{64451989000200004 \& \operatorname{lng}=\mathrm{en} \& \mathrm{nrm}=\mathrm{iso}>}>$. Acesso em 20 jul. 2016.

- Movimentos sociais, renovação cultural e o papel do conhecimento. Novos estudos, $\quad \mathrm{n}^{\mathrm{0}} \quad 40 . \quad$ Nov. 1994. Disponível em: < http://novosestudos.uol.com.br/v1/contents/view/641>. Acesso em 13 jul. 2016.

. A invenção do presente: movimentos sociais nas sociedades complexas. Tradução Maria do Carmo Alves Bomfim. Petrópolis, RJ: Vozes, 2001.

. O jogo do eu: a mudança de si em uma sociedade global. Trad., Adriano R. Marinho, Agostino Giacomini, Débora Conforto, Henri Fuchs, Jorge D. Barbosa, Jorge M. Adão, José Rossi, Nara R. Vieira, Raquel Gatto, Sueli Salva. São Leopoldo, RS: Editora Unisinos, 2004.

MENDES, Eniceia Gonçalves. A radicalização do debate sobre inclusão escolar no Brasil. Revista Brasileira de Educação, v.11, n. 33, set. a dez. 2006. Disponível em: < http://www.scielo.br/pdf/rbedu/v11n33/a02v1133.pdf $>$. Acesso em: 26 jun. 2017.

MINAYO, Maria Cecilia de S. Ciência, técnica e arte: o desafio da pesquisa social. In: MINAYO, Maria Cecilia de S. (Org.) Pesquisa social: teoria, método e criatividade. $23^{\mathrm{a}}$ ed. Petrópolis, RJ: Vozes, 2004, p. 9-29.

O desafio da pesquisa social. In: MINAYO, Maria Cecília de S. (org.). Pesquisa $\overline{\text { social: }}$ teoria, método e criatividade. $34^{\mathrm{a}}$ ed. Petrópolis, RJ: Vozes, 2015, p. 9-29.

MIRANDA, Camila M.; CASTILHO, Neuza A. N.; CARDOSO, Vanessa C. C. Movimentos sociais e participação popular: luta pela conquista dos direitos sociais. Revista da Católica, Uberlândia, v. 1, n. 1, 2009, p. 176-185. Disponível em: < http://www.catolicaonline.com.br/revistadacatolica2/artigosv1n1/15_Movimentos_socia is.pdf $>$. Acesso em 20 set. 2016.

MIRANDA, Arlete Aparecida Bertoldo. Educação Especial no Brasil: Desenvolvimento Histórico. Cadernos de História da Educação, v. 7, jan. a dez. 2008, p. 29-44. Disponível em: $<$ http://www.seer.ufu.br/index.php/che/article/view/1880/1564>. Acesso em 31 mai. 2017.

MONTEIRO, Myrna Salerno. História dos Movimentos dos Surdos e o reconhecimento da Libras no Brasil. Educação Temática Digital, v. 7, n.2, p. 279-289. Campinas, jun. $2006 . \quad$ Disponível em: $<$ http://www.ssoar.info/ssoar/bitstream/handle/document/10178/ssoar-etd-2006-2- 
monteiro-historia_dos movimentos dos_surdos.pdf?sequence=1>. Acesso em 19 jun. 2017.

MOURA, Maria Cecília. O Surdo: Caminhos para uma nova identidade. São Paulo: Revinter, 2000.

.; LODI, Ana Claudia B.; HARRISON, Kathryn M. P. História e educação: o surdo, a oralidade e o uso de sinais In: LOPES FILHO, O. (Ed) Tratado de Fonoaudiologia. $2^{\mathrm{a}}$ ed. Ribeirão Preto: Tecmedd, 2005, p. 341-364.

MOURA, Vera Lucia Pereira da Silva, SERRA, Maria Luiza A. A. Educação de Jovens e adultos: as contribuições de Paulo Freire. Trabalho de Conclusão de Curso de PósGraduação a distância Lato Sensu em Educação de Jovens e Adultos (EJA), Universidade Católica Dom Bosco, 2014. Disponível em: $<$ https://www.inesul.edu.br/revista/arquivos/arq-idvol_33 1426693042.pdf $>$. Acesso em 5 mai. 2017.

MUYLAERT, Camila J.; JUNIOR, Vicente Sarubbi; GALLO, Paulo R.; NETO, Modesto L. Rolim; REIS, Alberto O. A. Entrevistas narrativas: um importante recurso em pesquisa qualitativa. Revista da Escola de Enfermagem da USP [Online], v. 48, n. 2. São Paulo, dez. 2014, p. 193-199. Disponível em: < http://www.scielo.br/pdf/reeusp/v48nspe2/pt 0080-6234-reeusp-48-nspe2-00184.pdf $>$. Acesso em 04 out. 2016.

OLIVEIRA, Dalila Andrade. As políticas educacionais no governo Lula: rupturas e permanências. Revista Brasileira de Políticas e Administração da Educação, v. 25, n. 2 , p. 197-209, mai. a ago. 2009. Disponível em: <http://seer.ufrgs.br/rbpae/article/view/19491/11317>. Acesso em 20 jun. 2017.

PEREGRINO, Giselly dos S. Realizar entrevistas à luz de Bakhtin. IV Colóquio Internacional - Educação, Cidadania e Exclusão: didática e avaliação, v. 1. Rio de Janeiro, 2015, $\quad$ p. 1-9. Disponível em: < http://www.editorarealize.com.br/revistas/ceduce/trabalhos/TRABALHO EV047 MD1 SA10_ID663 01052015195239.pdf>. Acesso em 10 set. 2016.

PICOLOTTO, Everton L. Movimentos sociais: abordagens clássicas e contemporâneas. Revista Eletrônica de Ciências Sociais [Online], ano I, ed. 2, nov. 2007, p. 156-177.

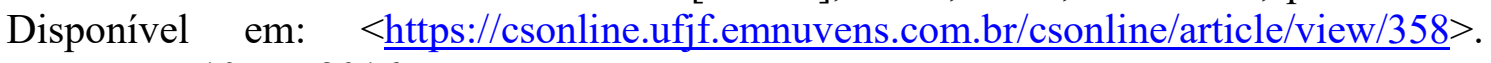
Acesso em 10 set. 2016.

POCHMANN, Marcio. Políticas Sociais e padrão de mudanças no Brasil durante o governo Lula. Revista Ser Social, v. 13, n. 28, 2011. Disponível em: < http://periodicos.unb.br/index.php/SER_Social/article/view/5620>. Acesso em 29 jun. 2017.

RAMOS, Clélia Regina. Histórico da Feneis até o ano de 1988. Petrópolis, RJ: Arara Azul, 2007. Disponível em: <http://www.editora-arara-azul.com.br/pdf/artigo6.pdf $>$. Acesso em 28. Jun. 2017.

RANGEL, Gisele Maciel Monteiro. História do povo surdo em Porto Alegre: imagens e sinais de uma trajetória cultural. 2004. 157. Dissertação de mestrado, Universidade Federal do Rio Grande do Sul, Porto Alegre. Disponível em: < 
http://www.lume.ufrgs.br/bitstream/handle/10183/5148/000510697.pdf > . Acesso em 17 abr. 2017.

REIS, Ana Carolina dos; PADILHA, Caio A. T. Educar para o trabalho: um breve estudo sobre o ensino profissionalizante na era Vargas (1930-1945) e no governo JK (19561961). Anais do VII Seminário do trabalho: trabalho, educação e sociabilidade. 24 a 28 mai. 2010. Disponível em: < http://www.estudosdotrabalho.org/anais-vii-7-seminariotrabalho-ret-

2010/Caio Augusto Toledo Padilha e Ana Carolina Godinho Reis UM BREVE_E STUDO ENSINO PROFISSIONALIZANTE ERA VARGAS JK.pdf $>$. Acesso em 12 nov. 2016.

ROCHA, Solange M. da. O INES e a educação de surdos no Brasil: aspectos da trajetória do Instituto Nacional de Educação de Surdos em seu percurso de 150 anos. Rio de Janeiro: INES, 2008.

SÃO PAULO (Município). Decreto n. 34. 380, de 29 de dezembro de 1958. Cria no Departamento de Educação o Serviço de Educação de Surdos-Mudos. Disponível em: $<$ http://www.al.sp.gov.br/repositorio/legislacao/decreto/1958/decreto-34380-

29.12.1958.html >. Acesso em 25 jun. 2017.

Decreto n. 47.186, de 21 de novembro de 1966. Institui o Serviço de Educação Especial no Departamento de Educação e dá outras providências. Disponível em: $<$ http://www.al.sp.gov.br/repositorio/legislacao/decreto/1966/decreto-47186-

21.11.1966.html>. Acesso em 25 jun. 2017.

. Lei n. 10.038, de 05 de fevereiro de 1968. Dispõe sobre a organização do Sistema de Ensino do Estado de São Paulo. Disponível em: < http://www.al.sp.gov.br/repositorio/legislacao/lei/1968/lei-10038-05.02.1968.html>. Acesso em 25 jun. 2017.

Lei n. 10.125, de 4 de junho de 1968. Instituto o Código de Educação do Estado de São Paulo. Disponível em: $<$ http://www.al.sp.gov.br/repositorio/legislacao/lei/1968/lei-10125-04.06.1968.html $>$. Acesso em 25 jun. 2017.

Decreto n. 52.324, de 1 de dezembro de 1969. Dispõe sobre a organização da Coordenadoria do Ensino Básico e Normal da Secretaria da Educação, e providências correlatas.

em:

$<$ http://www.al.sp.gov.br/repositorio/legislacao/decreto/1969/decreto-5232401.12.1969.html >. Acesso em 25 jun. 2017.
Deliberação
CEE
$13 / 73$.
Disponível
em:

http://iage.fclar.unesp.br/ceesp/textos/1973/del_13_73_s_Heitor_c_rodolfo_w_rodolfo. pdf. Acesso em jul. 2017.

Decreto n. 7510, de 29 de janeiro de 1976. Reorganiza a Secretaria de Estado da Educação. 
Lei n. 13.304, de 21 de janeiro de 2002. Reconhece, no âmbito do Município de São Paulo a Língua Brasileira de Sinais, LIBRAS, como língua de instrução e meio de comunicação objetiva e de uso corrente da comunidade surda, e dá outras providências. Disponível em: $<$ http://webcache.googleusercontent.com/search?q=cache:KnhkCroklmkJ:www.prefeitu ra.sp.gov.br/cidade/secretarias/upload/educacao/cme/LEI\%2520_13304_02.doc+\&cd=1 $\underline{\& h l=p t-B R \& c t=c l n k \& g l=b r}>$. Acesso em 7 jun. 2017.

Portaria n. 5707, de 12 de dezembro de 2011. Regulamenta o Decreto 52.785 de 10 de outubro de 2011 que criou as Escolas de Educação Bilíngue para Surdos - EMEBs na Rede Municipal de Ensino e dá outras providências. Disponível em: $<$ http://www3.prefeitura.sp.gov.br/cadlem/secretarias/negocios juridicos/cadlem/integr a.asp?alt=13122011P\%20057072011SME> . Acesso em 19 mai. 2017.

SÃO PAULO. Encontro reúne deficientes auditivos de EMEEs. (Portal). Disponível em: $<$ http://www.prefeitura.sp.gov.br/cidade/secretarias/comunicacao/noticias/?p=140000 $>$. Acesso em 14 mai. 2017.

SILVA, Cesar A. de A.; ASSÊNSIO, Cibele B.; SANDES, Leslie L.; ALMEIDA, Priscila Alves de. Dia do Surdo na Avenida Paulista: Etnografando a Mobilização Política pelas Escolas Especiais. Ponto Urbe (Online), 5, 2009. Disponível em: < http://pontourbe.revues.org/1602>. Acesso em 3 out. 2016.

SILVA, César A. de A.; ASSÊNSIO, Cibele B. Setembro Azul: mobilização política nacional a favor das escolas bilíngues para surdos. Ponto Urbe (Online), 9, 2011. Disponível em: < http://pontourbe.revues.org/1966> . Acesso em 3 out. 2016.

SPOSITO, Marília P. Juventude e Educação: interações entre a educação escolar e a educação não formal. Revista Educação \& Realidade, v. 33, n. 2, jul-dez, 2008, p. 83-98. Disponível em: $<$ http://seer.ufrgs.br/educacaoerealidade/article/view/7065> $>$. Acesso em 18 ago. 2016.

. A ilusão fecunda: a luta por educação nos movimentos populares. São Paulo: Hucitec, 1993.

WELLER, Wivian. A atualização do conceito de gerações de Karl Mannheim. Revista Sociedade e Estado, v. 25, $\mathrm{n}^{\mathrm{o}}$ 2. Mai.-Ago. 2010. Disponível em: $<$ http://www.scielo.br/pdf/se/v25n2/04.pdf $>$. Acesso em 15 ago. 2016.

ZOVICO, Neivaldo Augusto. Diretores da Feneis participam do CONAE de São Paulo, fev. $2010 . \quad$ Disponível em:

$<$ http://acessibilidadeparasurdos.blogspot.com.br/2010/02/diretores-da-feneisparticiparam-do.html >. Acesso em 27 jun. 2017.

. Ong capacita os surdos sem acessibilidade de comunicação visual. Revista Nacional de Reabilitação Reação, ano XVII, no 97, mar. a abr. 2014, p. 66. Disponível $\mathrm{em}:<$ https://issuu.com/marketingcg12/docs/pdf_rea_____ed_97>. Acesso em 26 jun. 2017. 